I NTER NATIONAL MONETARY FUND

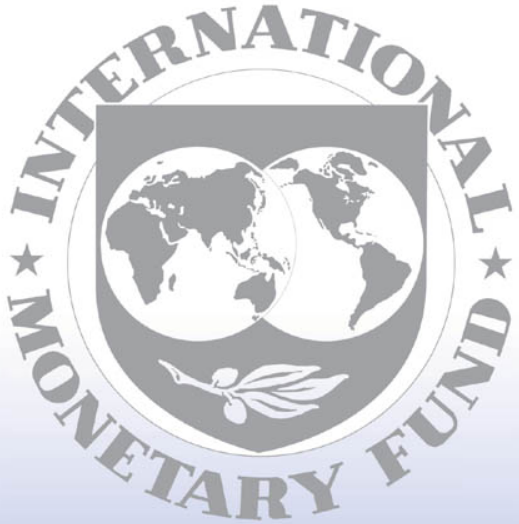

Staff

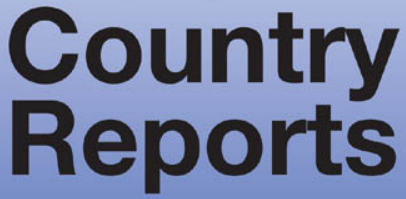




\section{Republic of Latvia: Fifth Review Under the Stand-By Arrangement and Financing Assurances Review, Request for Waiver of Nonobservance of a Performance Criterion, and Proposal for Post-program Monitoring}

The following documents have been released and are included in this package:

- $\quad$ The staff report, prepared by a staff team of the IMF, following discussions that ended on November 7, 2011 with the officials of the Republic of Latvia on economic developments and policies. Based on information available at the time of these discussions, the staff report was completed on December 8,2011. The views expressed in the staff report are those of the staff team and do not necessarily reflect the views of the Executive Board of the IMF.

- Informational Annex.

- A Press Release.

- $\quad$ A statement by the Executive Director for the Republic of Latvia.

The document(s) listed below will be separately released.

Letter of Intent sent to the IMF by the authorities of the Republic of Latvia*

*Also included in Staff Report

The policy of publication of staff reports and other documents allows for the deletion of market-sensitive information.

$$
\begin{gathered}
\text { Copies of this report are available to the public from } \\
\text { International Monetary Fund • Publication Services } \\
70019^{\text {th }} \text { Street, N.W. • Washington, D.C. 20431 } \\
\text { Telephone: (202) 623-7430 • Telefax: (202) 623-7201 } \\
\text { E-mail: publications@imf.org Internet: http://www.imf.org }
\end{gathered}
$$

\section{International Monetary Fund \\ Washington, D.C.}




\title{
REPUBLIC OF LATVIA
}

\section{Fifth Review Under the Stand-By Arrangement and Financing Assurances Review, Request for Waiver of Nonobservance of a Performance Criterion, and Proposal for Post-Program Monitoring}

\author{
Prepared by the European Department \\ (In Consultation with Other Departments)
}

Approved by Anne-Marie Gulde-Wolf and Claire Waysand

December 8, 2011

- Stand-By Arrangement. A 27-month SDR 1.52 billion exceptional access SBA (1,071 percent of revised quota) was approved by the Executive Board on December 23, 2008 (Country Report No. 09/3), and extended to December 22, 2011 in February 2010 at the Second Review. So far, SDR 982 million has been purchased. A further SDR 539 million (approximately €620 million) is available on completion of this Fifth and final review of the arrangement, but the authorities have indicated they do not intend to draw this amount.

- Economic Developments and Program Status. Latvia's program has delivered on many of its objectives. The economy continues to recover and inflation appears to have peaked, but unemployment and poverty remain high, and output remains well below pre-crisis levels. The euro area debt crisis has affected Latvia less than many other CEE countries, but could increase capital outflows and financing risks. The authorities met all end-August performance criteria and endJune and end-September indicative targets, but progress on most structural benchmarks was delayed due to unexpected parliamentary elections in September. Most of these-including submission of a Fiscal Discipline Law (FDL) to Parliament and a sales strategy for Mortgage and Land Bank (MLB) to the EC - have now been met, but sale of the commercial part of MLB is not expected to be completed till next year. Staff supports the authorities' request for a waiver of a continuous performance criterion due to an exchange restriction. Discussions focused on the 2012 budget, a framework to anchor fiscal policy after the program ends, implementation of the sales strategy for MLB, and safeguards to protect against further losses in airBaltic. After the mission ended, staff discussed the state's intervention in the failed bank Krajbanka and its implications for financial sector stability, and the nationalization of airBaltic.

- Discussions were held in Riga October 4-11 and October 27-November 7. The mission met with Prime Minister Dombrovskis; Finance Minister Vilks; Bank of Latvia (BoL) Governor Rimšēvičs; the then Head of the Financial and Capital Market Commission (FCMC) Krūmane; senior officials in these institutions and other government agencies; coalition and opposition political parties; social partners including the trade unions and local governments; foreign ambassadors; media; and financial institution and other private sector representatives.

- Staff. The staff team comprised Mark Griffiths (head), Emilia Jurzyk, Magnus Saxegaard (all EUR), Alvar Kangur (FAD), David Parker (MCM), and Sergi Lanau (SPR). David Moore and Agnese Bukovska (Resident Representative's Office) assisted the mission. The team worked closely with staff of the European Commission (EC), European Central Bank (ECB), World Bank, and the Swedish authorities. Gundars Davidsons (OED) attended some meetings. 


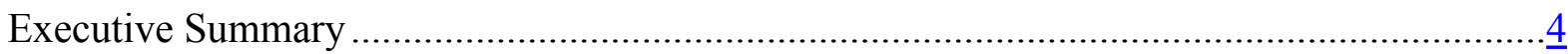

I. Introduction and Program Achievements …………...................................................

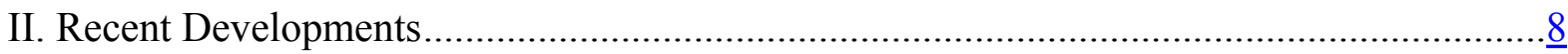

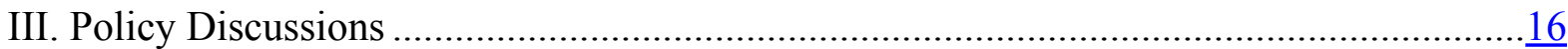

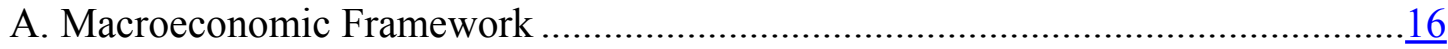

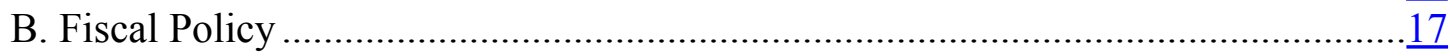

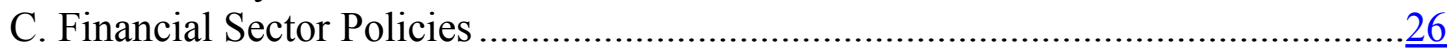

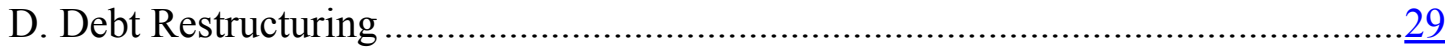

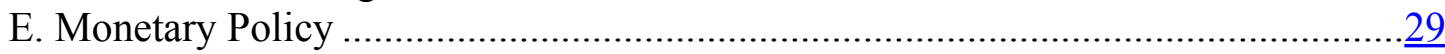

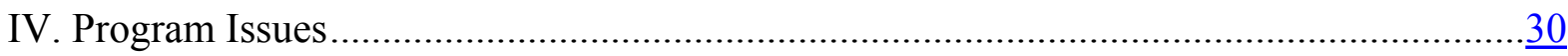

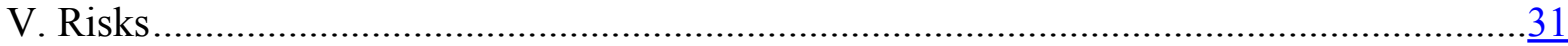

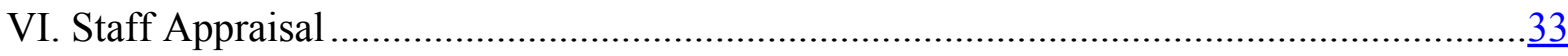

Boxes

1. The October 2011 Agreement to Bailout airBaltic ..........................................................

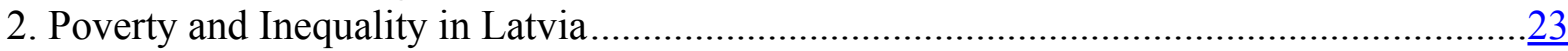

Tables

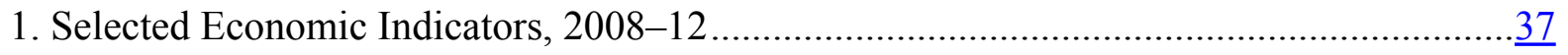

2. Macroeconomic Framework, 2010-16 ...................................................................

3. General Government Operations, 2010-13 ………....................................................

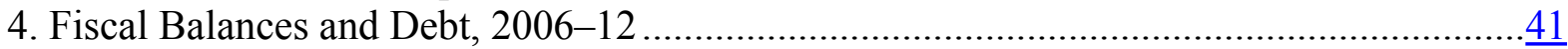

5. Public Sector Sustainability Framework, 2006-16 ……..............................................42

6. Medium-Term Balance of Payments, 2010-16 …………………….............................4

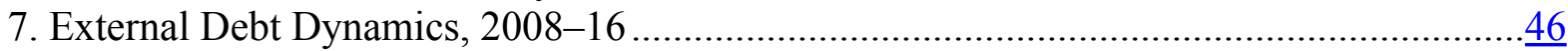

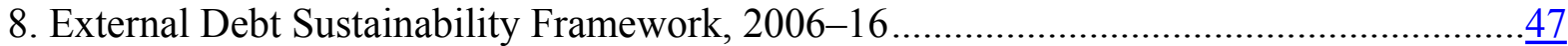

9. Bank of Latvia Balance Sheet, 2008-12 …................................................................

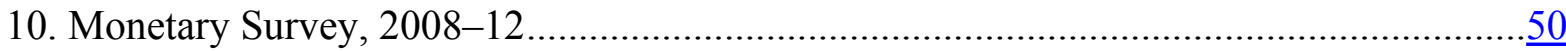

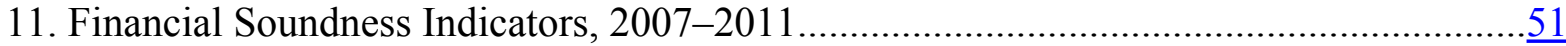

12. Selected Vulnerability Indicators, 2007-11 ……......................................................

13. Proposed Schedule of Reviews and Purchases .............................................................53

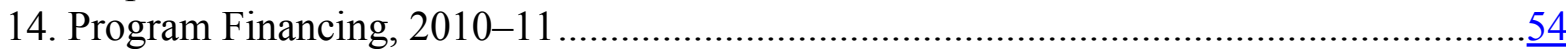

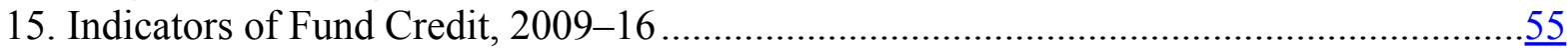

Figures

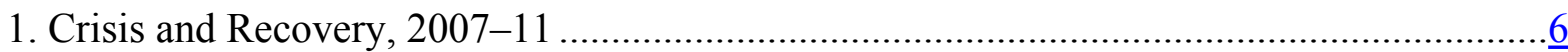

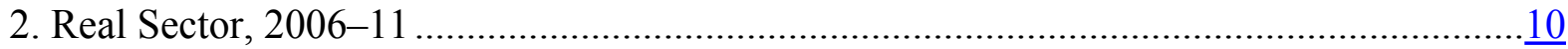

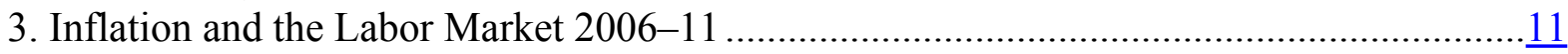

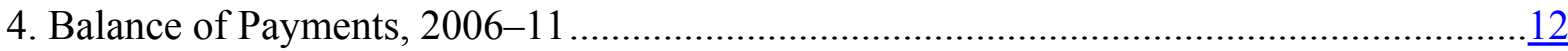




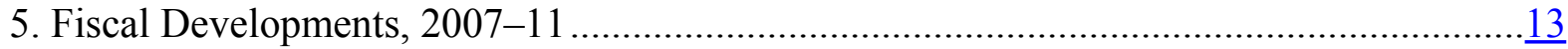

6. International Reserves and Financial Market Development, 2009-11 …...........................14

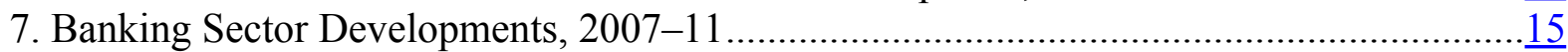

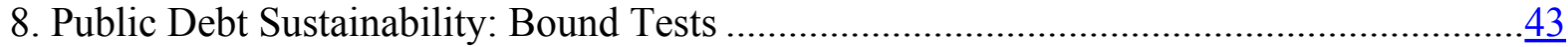

9. External Debt Sustainability: Bound Tests ...............................................................

Attachment:

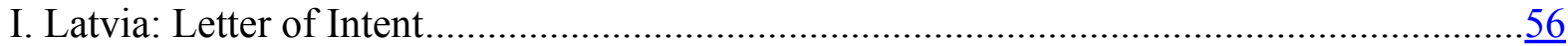




\section{EXECUTIVE SUMMARY}

Latvia's program has achieved many of its main objectives. International reserves have recovered to above pre-crisis levels and the exchange rate peg has held. The financial sector has strengthened, while fiscal adjustment of around 15 percent of GDP has preserved fiscal sustainability.

Competitiveness has improved but this was accompanied by a collapse in output, high unemployment, and (despite the program's emphasis on emergency safety nets) increasing poverty, while external debt and problem assets in the banking sector have also increased.

The economy continues to recover, but the worsening global outlook is likely to hurt growth next year. Increasing domestic demand and exports are offsetting a sharp increase in imports, resulting in robust growth of 4.5 to 5 percent this year. Next year, a decline in external demand is projected to lower growth to around 2.5 percent; this could be optimistic if the euro area debt crisis were to worsen further. Inflation appears to have peaked, and should decline with falling international food and energy prices. Unemployment is expected to remain high, in part because of difficulties in reintegrating the long-term unemployed into the workforce.

\section{The euro area debt crisis - which is affecting Latvia but so far less than most other CEE} countries - raises important questions about the program's exit strategy of euro adoption. The 5-year CDS increased to $370 \mathrm{bps}$ in November, but this reflects the general increase in risk aversion. Rating upgrades to investment grade by Fitch facilitated the successful placement of a Eurobond in June, and domestic interest rates remain relatively low. However, a further deterioration in the euro area debt crisis could complicate plans to tap international capital markets next year and accelerate the repatriation of funds by foreign-owned banks.

\section{The authorities met all August performance criteria, and June and September indicative}

targets. September's unexpected elections delayed progress on many structural benchmarks, although most — including submission of an FDL to Parliament and a sales strategy for MLB to the EC — have now been met. Staff supports a waiver for the nonobservance of a continuous performance criterion due to an exchange restriction.

Discussions focused on the 2012 budget, restructuring of state-owned banks, and reorganization of airBaltic. The 2012 budget should lower the deficit to 2.5 percent (ESA95) on a sustainable basis, but the consolidation includes several poor quality measures and social safety net cuts. The authorities are proceeding with the sale of Citadele and the commercial part of MLB, but resisted calls to remove the banking license of the remaining development part of MLB to prevent it from becoming a future source of fiscal and financial stability risks. Despite strong staff concerns, the government bailed out the loss-making airBaltic in October at a cost of 0.4 percent of GDP, despite a lack of audited accounts and past governance problems. In late November (after the mission had ended) extensive fraud was discovered in Latvijas Krajbanka (Latvia's 10th largest bank). The FCMC placed it under official administration and plans to liquidate it without delay.

Implementation of the program has made the economy more robust to shocks, but risks remain that could derail the recovery and the goal of euro adoption. Spillovers from the euro area crisis could increase, reducing growth and increasing capital outflows, and complicate plans to tap international capital markets. Also, the sale of Citadele and the commercial part of MLB, if not handled properly, could temporarily increase financial stability risks, while airBaltic could require further government bailouts if attempts to return the airline to profitability prove unsuccessful. Krajbanka's failure points to a need to improve financial supervision and crisis resolution. 


\section{Introduction ANd Program AChiEvements}

\section{Latvia's program has delivered on many of its main objectives, although a number of vulnerabilities remain (Figure 1):}

- $\quad$ The exchange rate peg to the euro has held despite significant pressures early on in the program. Although international reserves fell by around 37 percent between September 2008 and June 2009 as customers withdrew their bank deposits and converted them into foreign currency, they have since risen above pre-crisis levels. The rebuilding of reserves reflects substantial financial assistance from the IMF and other donors, and also an improved current account and the successful return to international capital markets in June this year. While banks' deleveraging means that outflows are persisting, these no longer threaten the peg.

- $\quad$ Deposits are now above pre-crisis levels. Private deposits had declined by 19 percent between end-August 2008 and end-September 2009-much of these were non-resident deposits in the now-restructured Parex Bank-but prudential indicators show the banking system has since strengthened significantly (Table 11). Emergency liquidity assistance provided by the BoL to meet these deposit withdrawals was repaid in full in August 2010.

- The authorities have implemented substantial fiscal consolidation over the program period. Fiscal adjustment measures of around 15 percent of GDP - the bulk taken in 2009- have reduced the fiscal deficit from 9.7 percent of GDP (ESA95) in 2009 to a projected 4 percent of GDP in 2011. The fiscal consolidation has brought Latvia close to meeting the Maastricht fiscal criterion and reduced financing risks.

The authorities' macroeconomic strategy has centered on substantial wage and price cuts and productivity growth to improve competitiveness and reduce external imbalances. Domestic price inflation has been low, while wages fell by 13.6 percent from the end of 2008 through early 2010. This has contributed to a 10 percent depreciation of the CPI-based real effective exchange rate from its 2009 peak, while the ULC-based rate has depreciated 22 percent. The current account deficit—which peaked at 22.5 percent in 2007—moved to a surplus of more than 8 percent of GDP in 2010, but is now falling back toward balance.

- However, these competitiveness improvements have come at the cost of substantial declines in economic activity and job losses. GDP fell 21 percent from 2007 to 2010 and remains well-below pre-crisis levels, while unemployment rose to 20.7 percent (labor force survey) though has now fallen to 14.6 percent. Latvia's poverty rates remain among the highest in Europe, making the program's emergency social safety net critical. According to Eurostat data, severely materially deprived people accounted for 27.4 percent of the population in 2010 . 
Figure 1. Latvia: Crisis and Recovery, 2007-11

International reserves have returned to pre-crisis levels.

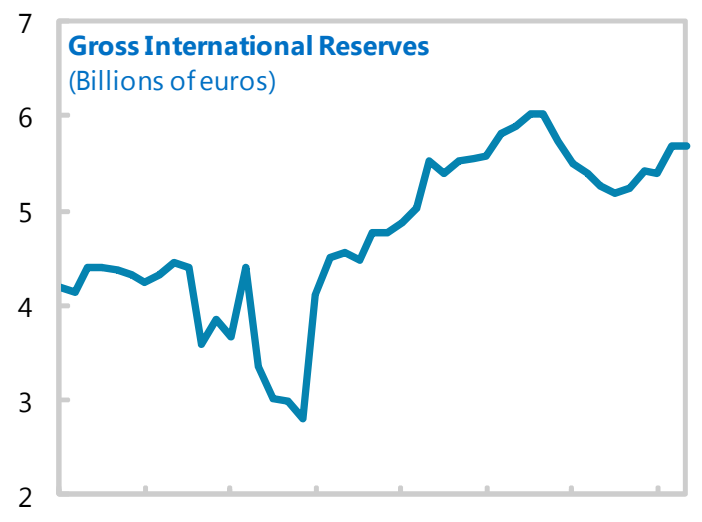

Jan-08 Jul-08 Jan-09 Jul-09 Jan-10 Jul-10 Jan-11 Jul-11

A very large fiscal consolidation has brought Latvia within

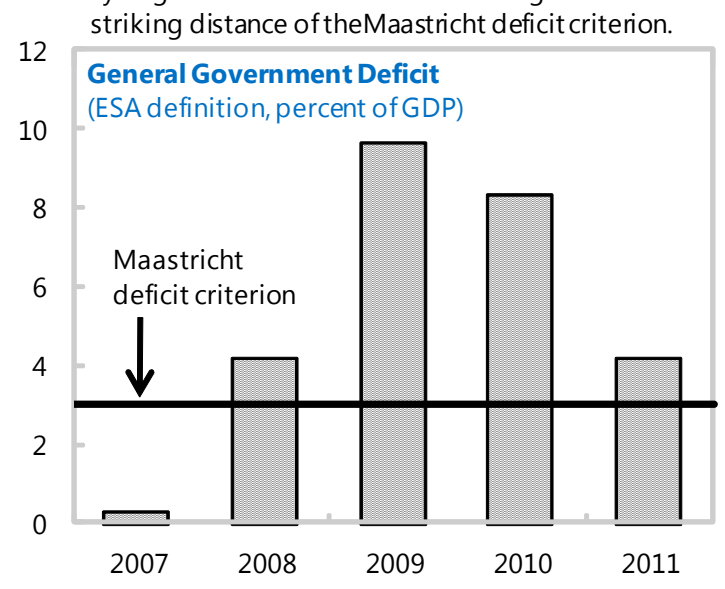

Unemployment remains high...

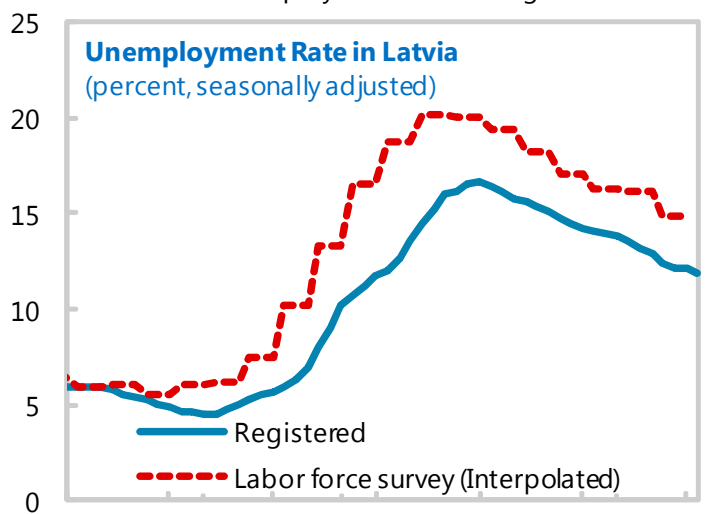

Mar-07 Dec-07 Sep-08 Jun-09 Mar-10 Dec-10 Sep-11
Deposits have also recovered.

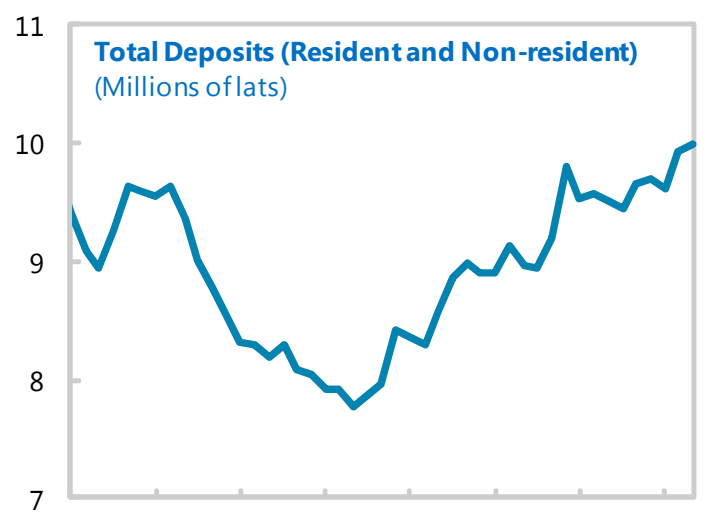

Jan-08 Jul-08 Jan-09 Jul-09 Jan-10 Jul-10 Jan-11 Jul-11

However, the crisis led to a steep dedine in output, which is now recovering but remains well below its peak.
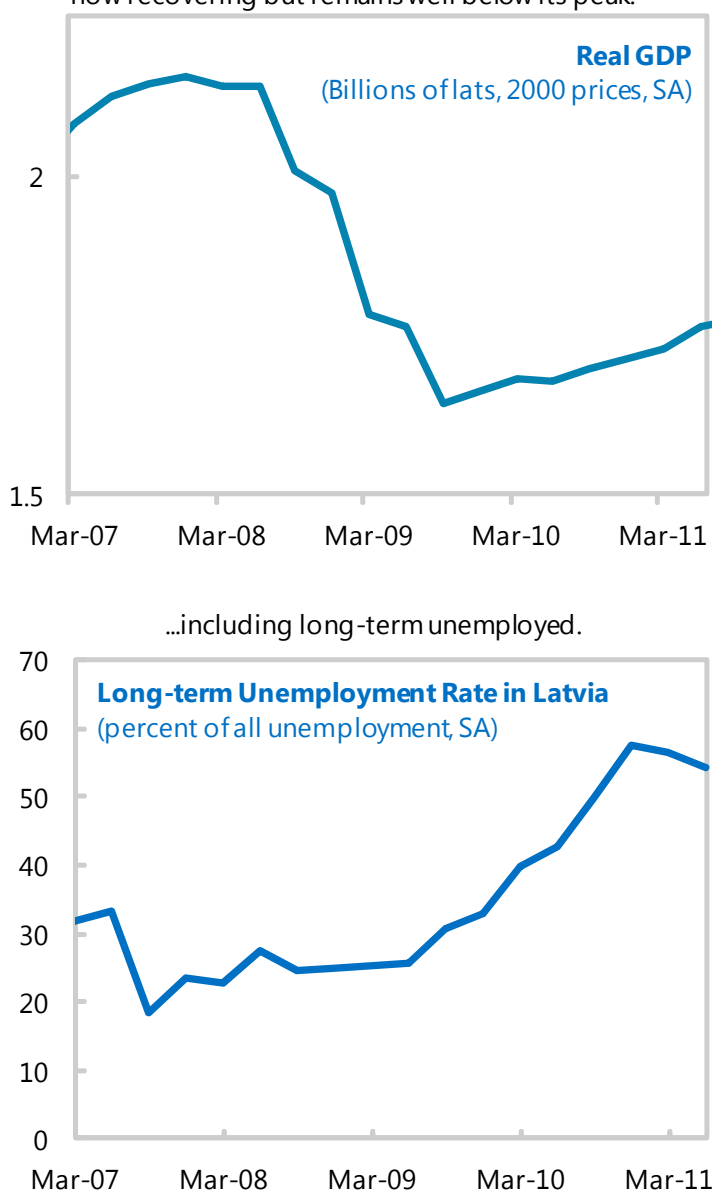

Sources: Bank of Latvia; Bloomberg; Haver; and IMF staff calculations. 
- $\quad$ Moreover, a number of vulnerabilities remain unresolved. Disbursement of program funds has resulted in an increase in the external debt to GDP ratio (though in line with original program projections and now declining); much of this debt will need to be repaid in 2014-15. Short-term external debt has also increased as a result of large inflows of non-resident deposits. And while the banking sector has returned to profitability, slow court and insolvency procedures mean that the share of nonperforming loans remains high at around 18 percent of total loans, constraining credit availability and domestic demand.

\section{Despite its success in maintaining the exchange rate peg, significant challenges} remain if Latvia is to sustain its economic recovery and achieve its goal of euro adoption in 2014. The authorities need to:

- Meet their LOI commitment to reduce the 2012 fiscal deficit to 2.5 percent of GDP (ESA95), and to do so on a sustainable basis. With the economy likely to weaken because of spillovers from the euro area, deficit reduction may not be easy. The bailout of airBaltic and the cost of resolving Krajbanka will increase government net debt and point to the importance of maintaining fiscal discipline in the broader public sector, not just in central and local government. Consolidation options agreed to earlier under the program - e.g. pension reform, real estate tax, and better targeting of social benefitshave been ruled out for political reasons; some reform fatigue has set in.

- Introduce institutional reforms, such as the Fiscal Discipline Law (FDL) and a Medium-Term Budget Framework, to make the recent consolidation permanent and to avoid a return to the pro-cyclical policies which contributed to the crisis.

- Accelerate the implementation of productivity-enhancing structural reforms to improve competitiveness and reduce unemployment. With the scope for further wage and price adjustment limited, structural reforms are essential if Latvia is to avoid exchange rate misalignment under its fixed exchange rate, even more so if it were to join the euro. The EC's various SMoUs have set out much of this agenda, but while there are many reports on what needs to be done, implementation has been weak so far.

- $\quad$ Manage the level of international reserves carefully. Reserves remain at relatively comfortable levels, but Latvia will need to tap international capital markets to meet relatively large repayments to official creditors through 2014. Further repatriation of funds by foreign banks operating in Latvia or an outflow of non-resident deposits are downside risks.

- Complete the restructuring or divestment of state-owned banks, and-in the wake of the failure of Krajbanka - strengthen the supervision of the financial sector, and their crisis preparedness to prevent a recurrence of vulnerabilities. The authorities should also assess their investments and address governance problems in other state-owned 
enterprises (e.g. airBaltic which was bailed out despite substantial losses and unaudited accounts) to ensure these are run efficiently and do not become fiscal drains. There has been little enthusiasm for privatization.

- $\quad$ Prepare contingency plans in case the euro area crisis intensifies.

3. Despite recent slippages, Latvia's performance through the program as a whole is a reasonably positive sign for the future. The authorities' policies - in particular the significant fiscal consolidation implemented in 2009-have overcome the crisis and restored stability. Credit rating upgrades by Moody's and Fitch to investment grade, this year's successful return to international capital markets through issuance of a US\$500 million bond, and the relative delinking of Latvia's bond yields from crisis countries in the euro area and in Eastern Europe reflect financial markets' confidence in the Latvian economy and in program implementation. On the basis of this performance, and the policy intentions in the current Letter of Intent, staff supports the authorities' request for completing the Fifth Review and financing assurances review.

\section{RECENT DEVELOPMENTS}

4. Recovery has continued through 2011, but external factors mean the outlook is worsening. The economy expanded faster than projected in the first half of 2011 led by increases in investment and private consumption, and is expected to grow by 4.5 to 5 percent in 2011 (Figure 2). The net export contribution was negative, however, as relatively strong export growth (led by chemical, mineral products, machinery, and electrical equipment) was offset by higher imports used as inputs for exports and resulting from the rebound in domestic demand. Short-term indicators are broadly positive; industrial production and retail sales (excluding motor vehicles) increased by 6.5 and 6.6 percent (seasonally adjusted) in the first 10 months of the year. However, Latvia is unlikely to remain unaffected by difficulties in the euro area, and survey data on confidence and new orders point to a coming slowdown.

5. Despite the recovery, the labor market remains weak. Employment has increased by almost 70,000 since the start of 2010, but the unemployment rate remains high at 14.6 percent (almost 165,000 people out of a labor force of around 1.1 million). More than half have been out of work for more than a year, so may now lack the necessary skills to regain employment, which would increase structural unemployment.

6. Consumer price inflation, which increased in the first half of 2011, now appears to be easing (Figure 3). HICP inflation peaked at 4.8 percent in May, mainly due to higher VAT and excises, and increases in international food and energy prices. It has eased in recent months. Despite an uptick, core inflation remains low because of high unemployment and the output gap. However, wage growth has accelerated to around 4 percent.

7. After falling nearly 15 percent since October 2010, international reserves have recovered following June's US\$500 million Eurobond and inflows of EU funds, and 
currently stand at $\mathbf{€ 5 . 6}$ billion (Figure 6). Deleveraging and the repayment of FX credit lines by Latvian banks have contributed to $€ 1.3$ billion in outflows this year. The current account has returned to a slight deficit as a result of the rebound in imports and the return to profitability of local subsidiaries of foreign banks.

8. Lower provisioning needs and funding costs have made banks profitable (Figure 7). Banks earned L66 million in profits in the first 9 months of the year, compared to a loss of L314 million in the same period last year. Together with capital injections and improved asset quality, the capital adequacy ratio has risen to 17 percent (14 percent Tier 1), significantly above the 8 percent regulatory minimum. Liquidity has declined as foreign banks have repatriated low-yielding deposits at the BoL (these have fallen 57 percent since end-2010) and have not rolled over foreign currency credit lines, but remains at comfortable levels. Banks have resumed some lending (notably to corporates and non-residents), but credit growth remains negative because of amortizations and loan write-offs. Contagion from the failure of Krajbanka has been limited thus far, with resident and non-resident deposits remaining broadly stable.

\section{The euro area sovereign debt crisis is affecting Latvia, but less so than in most} other CEE countries (Figure 6). Latvia's CDS increased to nearly 370bps in November (from a low of approximately $200 \mathrm{bps}$ earlier this year). However, this was well below levels observed in the euro area periphery and mirrored developments in neighboring Lithuania, which went through a less severe recession and did not request a Fund program. Successful placement of a Eurobond in June 2011 at a yield slightly above 5 percent ( 7 times oversubscribed) is further evidence of investor confidence in Latvia. However, a further worsening in financial conditions in Europe could complicate plans to tap international capital markets next year. Such tensions could also increase repatriation of funds by Swedish parent banks, who rely heavily on wholesale funding.

10. The euro area crisis also raises important questions about the exit strategy of the program - euro adoption. Although Latvia has made remarkable progress toward meeting the Maastricht criteria, the challenges facing the euro area itself may now overshadow this. Unless resolved, there is a risk these challenges could complicate Latvia's admission prospects. This could weaken the resolve for sustainable fiscal consolidation and economic reform. Continued worsening of the euro area crisis will require contingency plans, including additional fiscal measures.

\section{September's surprise parliamentary elections returned Prime Minister}

Dombrovskis to power as head of a new coalition government. The new coalitionconsisting of the ruling Unity Party, the newly formed Zatlers Reform Party (ZRP), and the National Alliance - supports the EU-IMF program and the goal of euro adoption in 2014. It has a tenuous parliamentary majority, as it depends on support from six parliamentarians who left ZRP during the coalition negotiations. Harmony Center, which has an ethnic Russian support 
Figure 2. Latvia: Real Sector, 2006-11
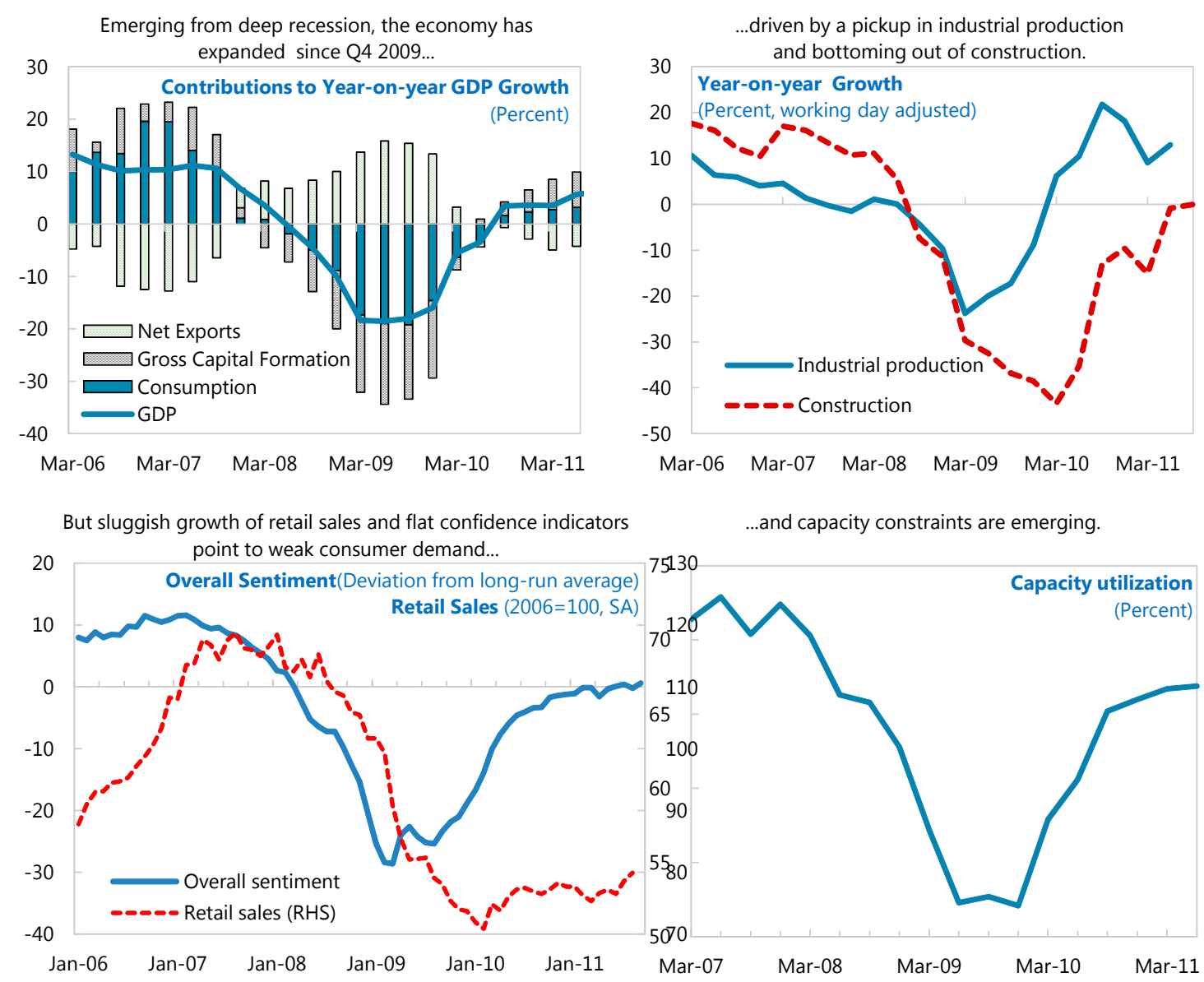

Meanwhile a decline in new orders for exports...
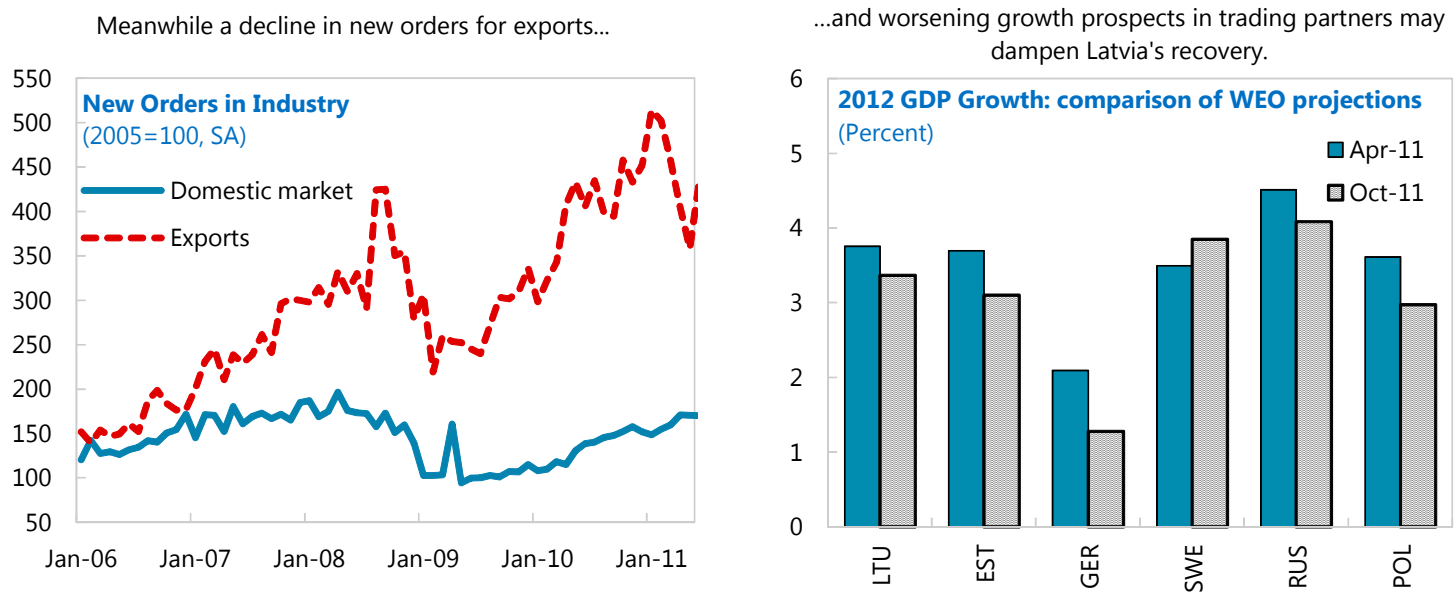

Sources: Latvian Central Statistical Bureau; Haver; and IMF staff calculations. 
Figure 3. Latvia: Inflation and the Labor Market, 2006-11

Inflation started to ease in mid-2011 ...

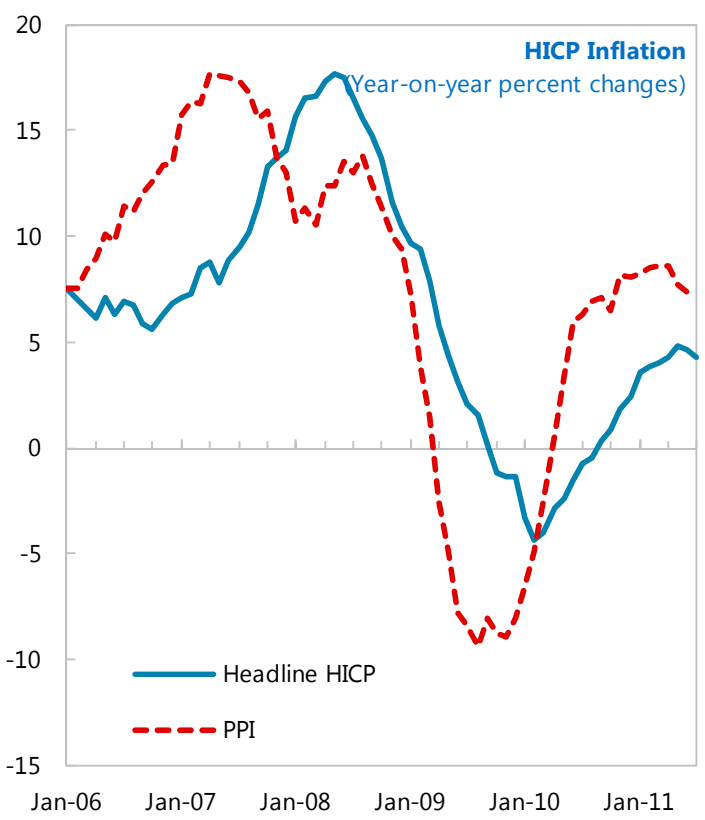

Wages have started growing again.

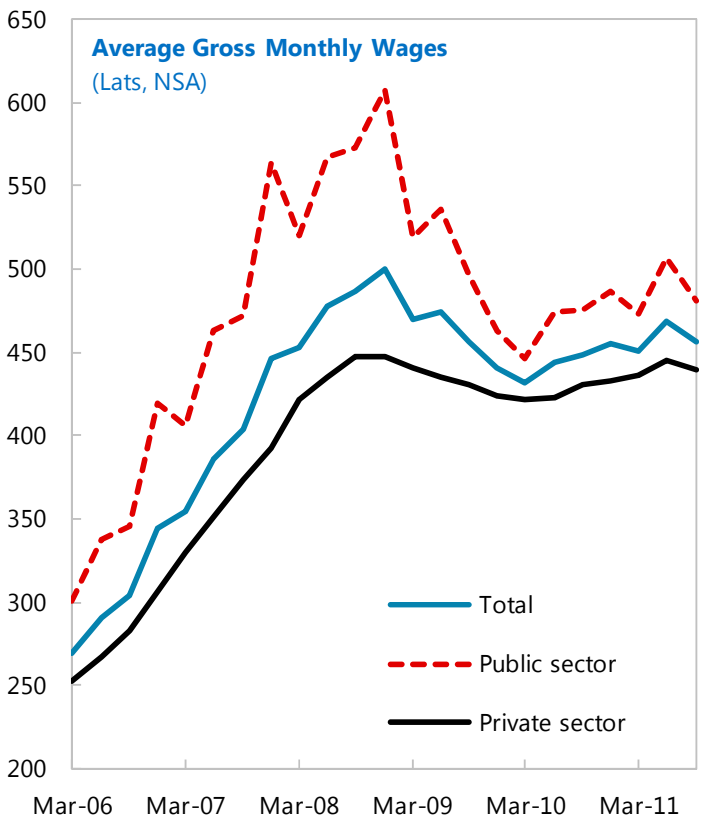

... reflecting declining food prices.

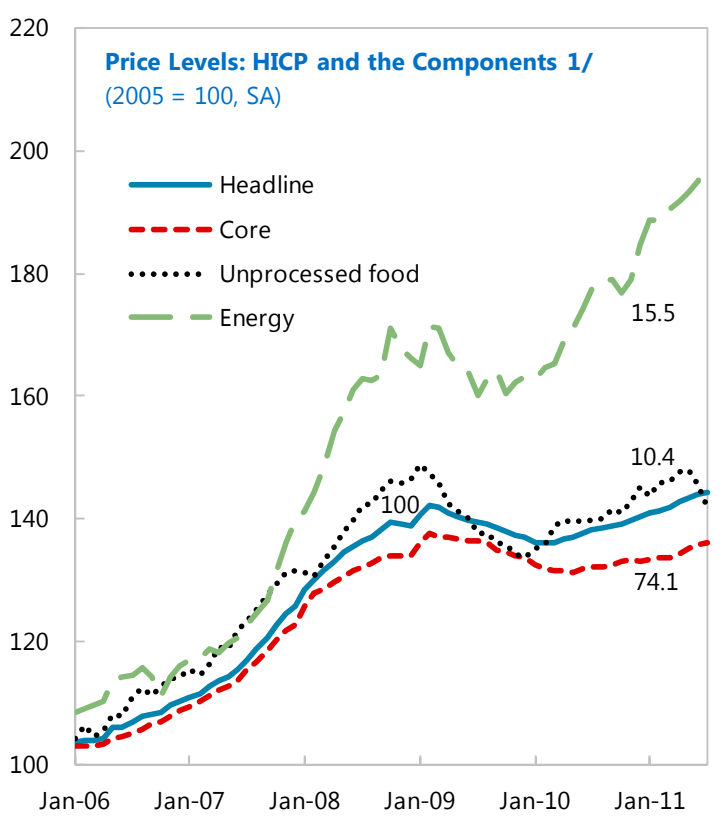

Latvia could meet the Maastricht inflation criterion in 2012, but the margin would be small.

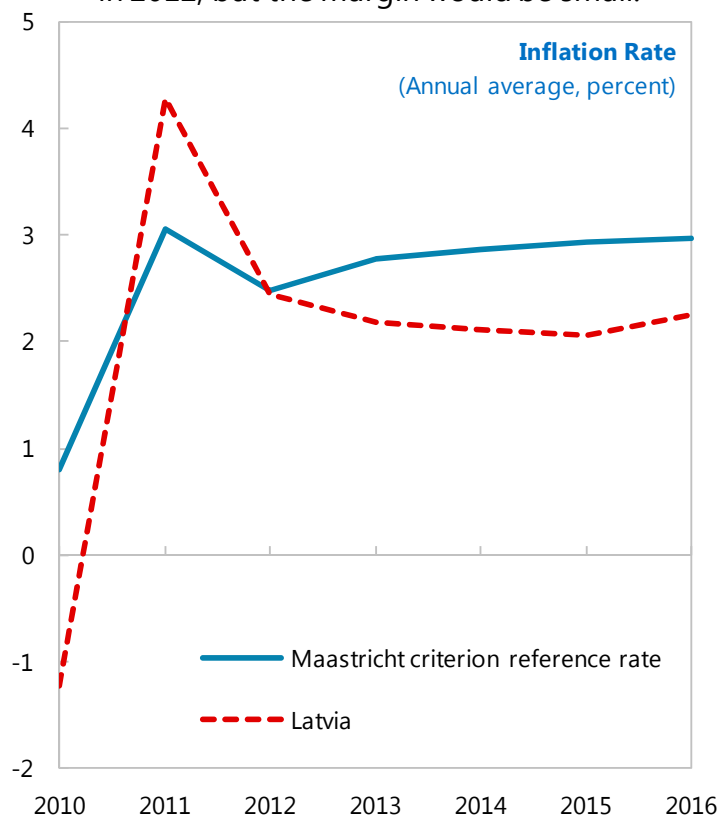

Sources: Eurostat; Haver; Latvian Central Statistical Bureau; and IMF staff calculations.

1/ Percentage weight of each component in 2011 HICP is indicated on the graph. 
Figure 4. Latvia: Balance of Payments, 2006-11

The current account was in small deficit in mid-2011, reflecting corrections in trade and income balances.

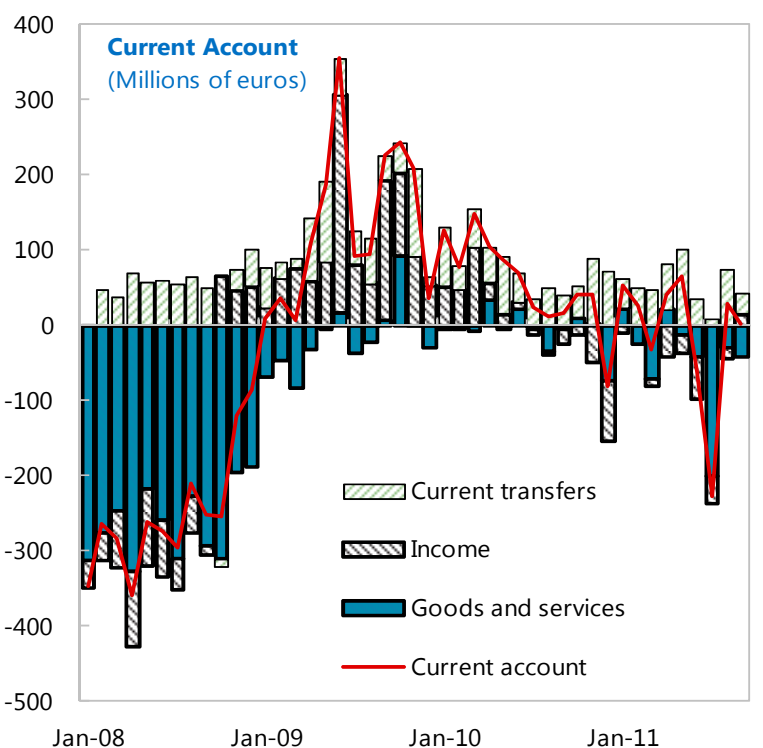

A Eurobond issue helped improve the capital and financial account.

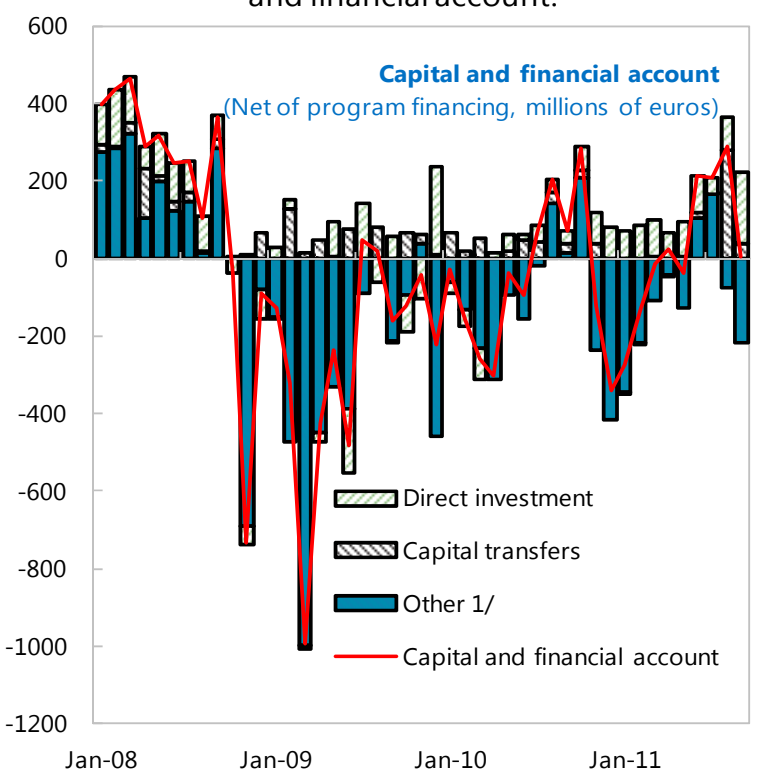

Imports are increasing faster than exports due to a recovery in domestic demand and re-exports.

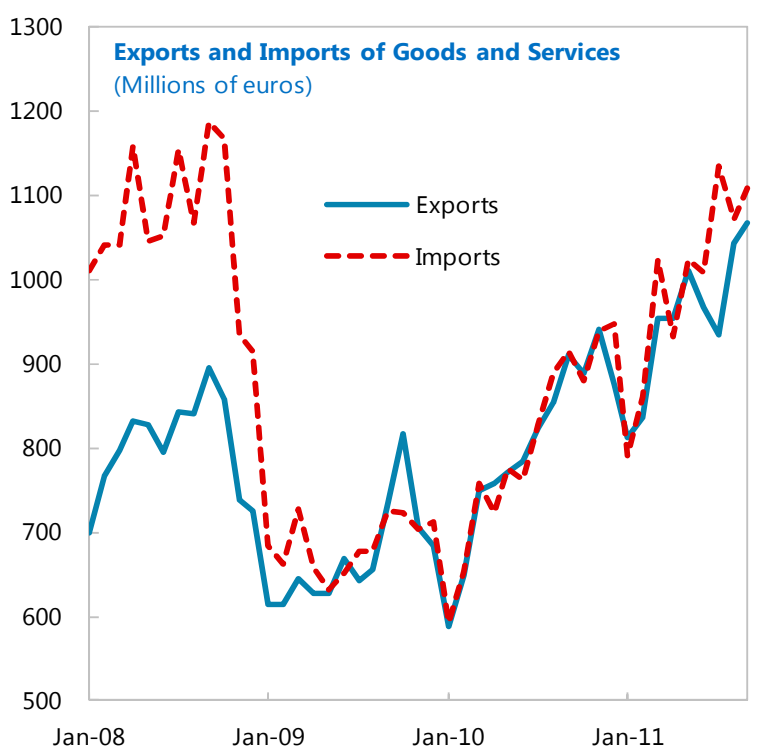

The sharp improvement in competitiveness has tapered off.

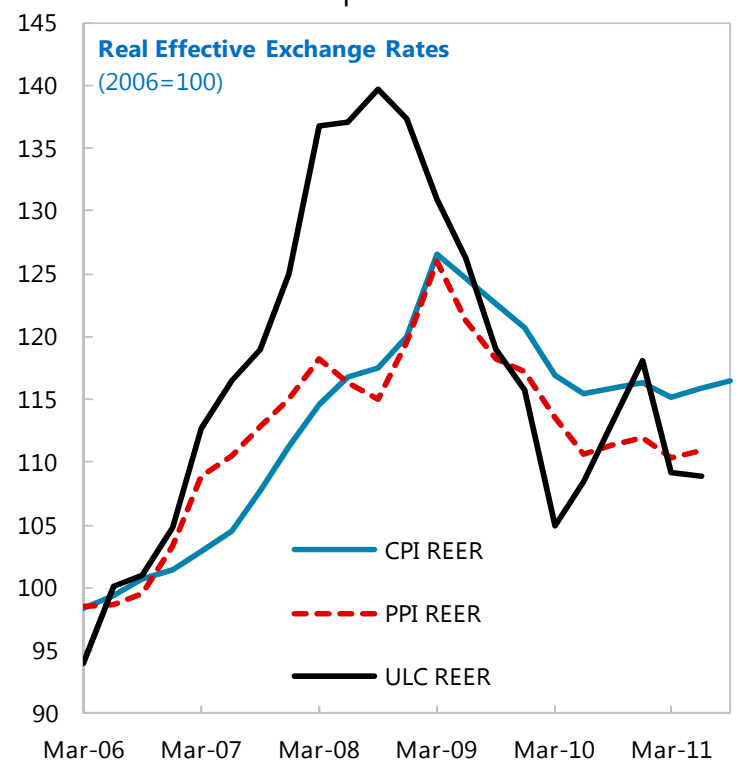

Sources: Bank of Latvia; ECB; and IMF staff calculations.

$1 /$ Other is the sum of other investment and portfolio investment and derivatives. In June 2011, the increase is driven by the issuance of a $\$ 500$ million Eurobond. 
Figure 5. Latvia: Fiscal Developments, 2007-11

Direct taxes have stabilized despite a reduction in the PIT rate, supported by an increase in the minimum wage.

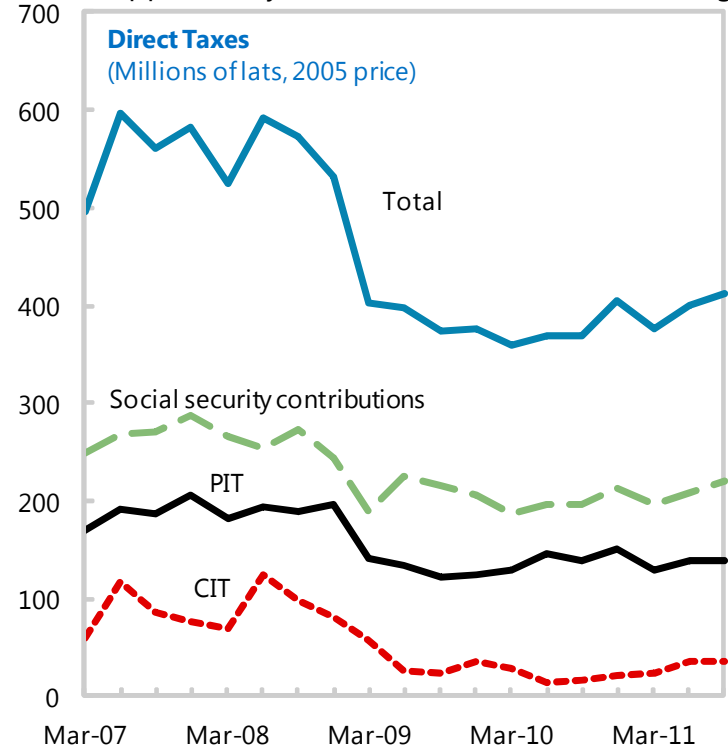

Spending pressures have started to emerge..

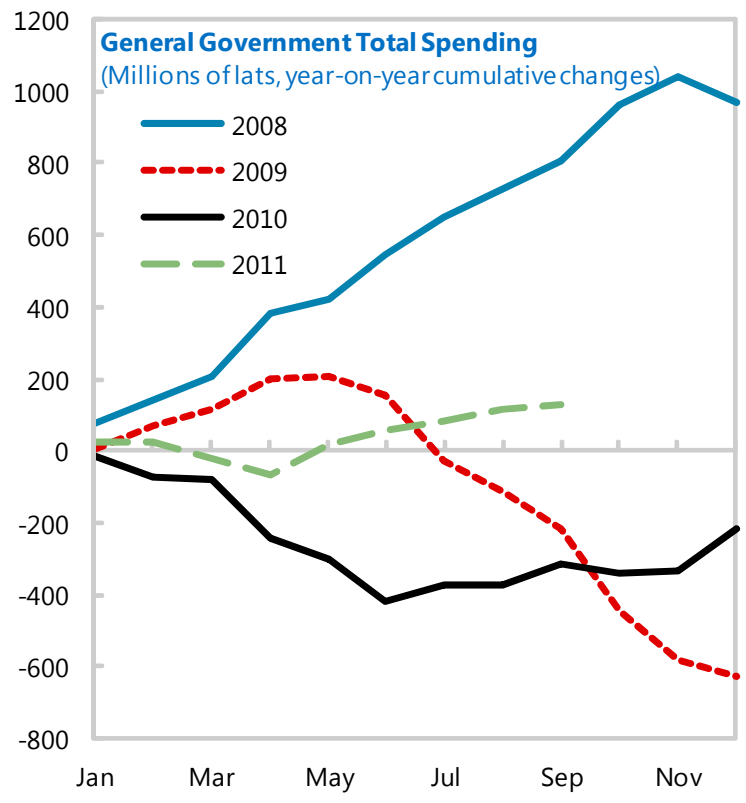

Indirect taxes have started to recover recently supported by an increased VAT rate.

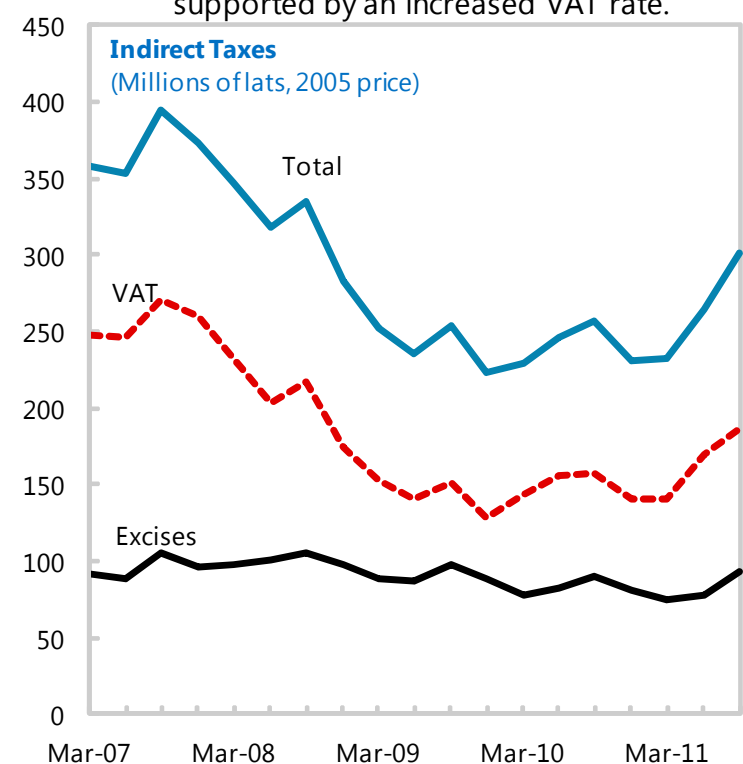

...offset by an expected inflow of EU-related funds that have helped to contain the cash deficit.

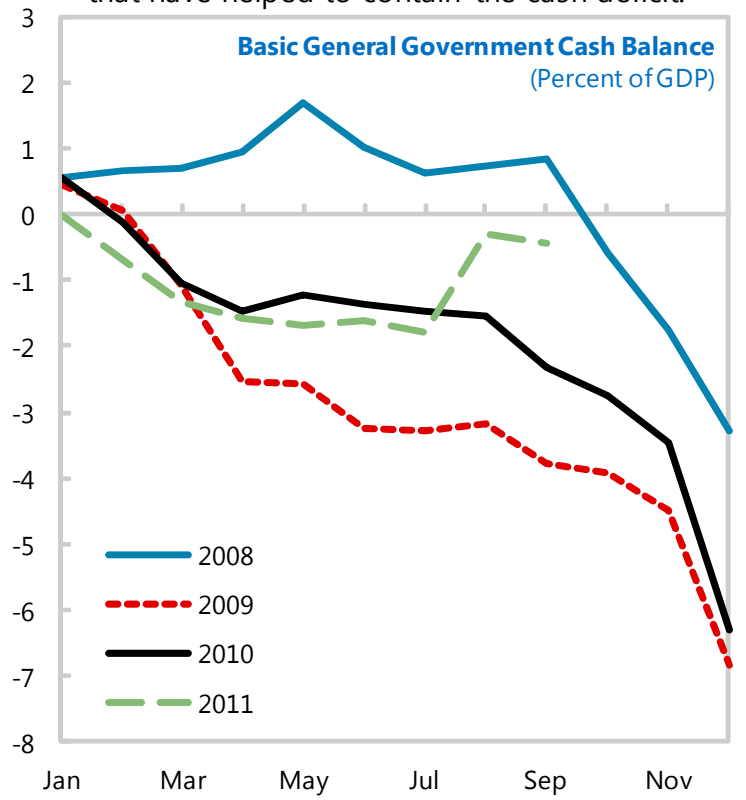

Sources: Latvian authorities; and IMF staff estimates. 
Figure 6. Latvia: International Reserves and Financial Market Developments, 2009-11

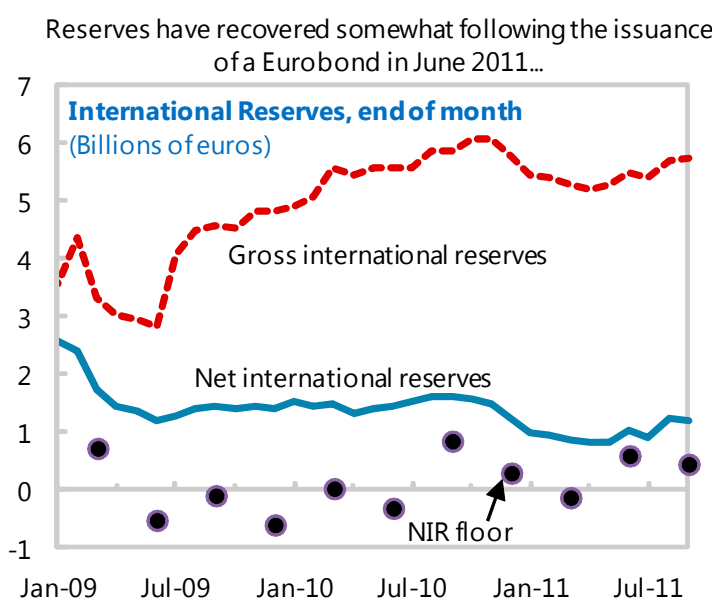

FX sales have appreciated the exchange rate back to

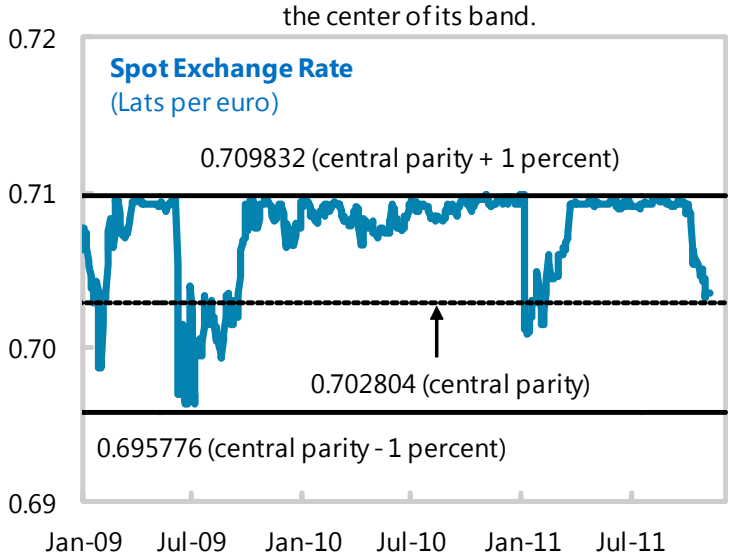

Swedish parent banks are suffering from the European

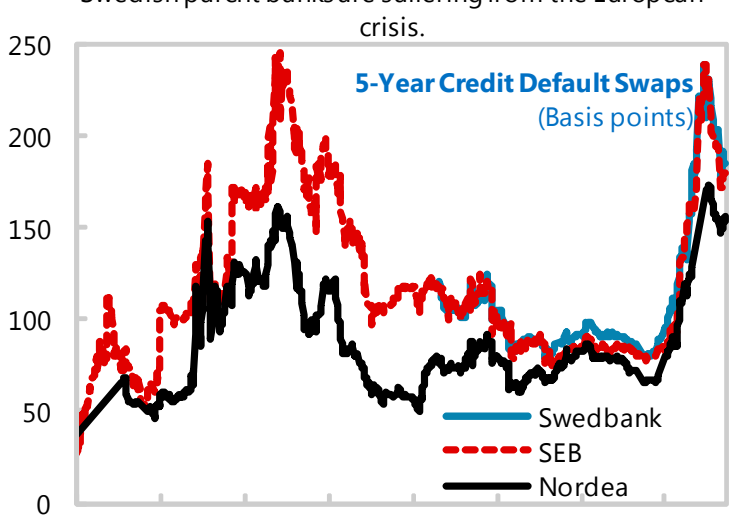

Jan-08 Jul-08 Jan-09 Jul-09 Jan-10 Jul-10 Jan-11 Jul-11
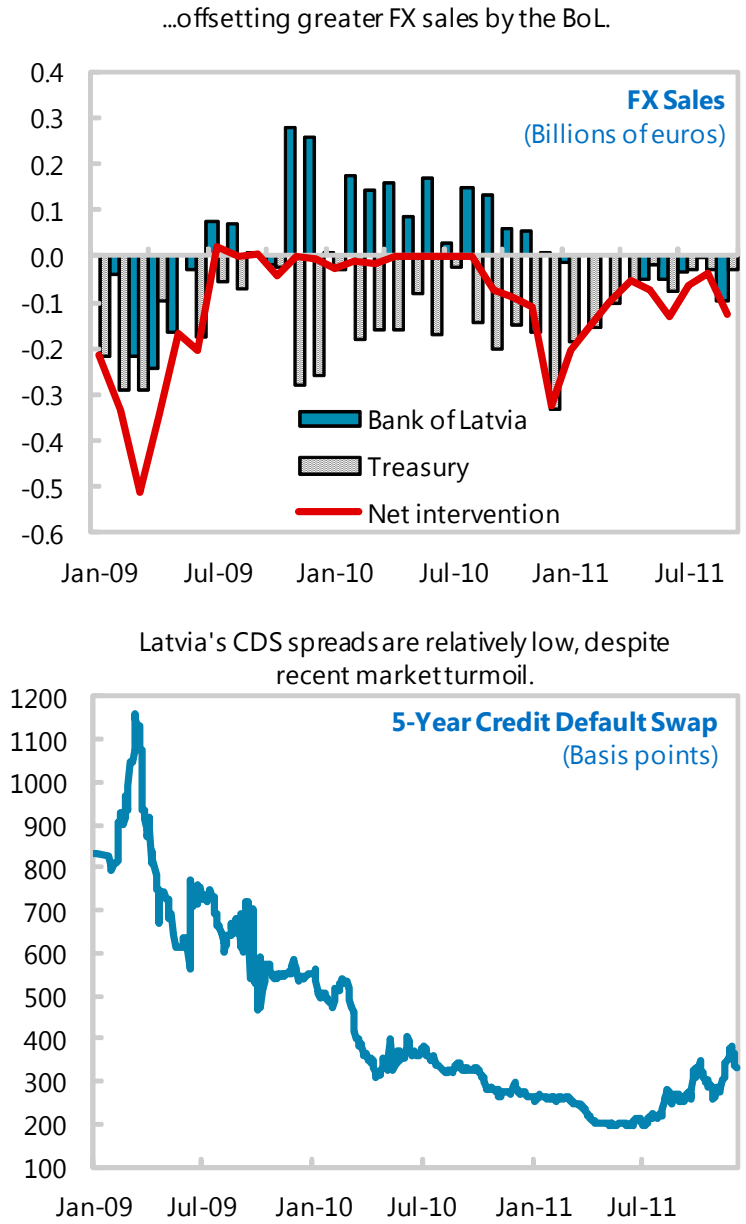

Bond spreads have risen but remain at managable levels.

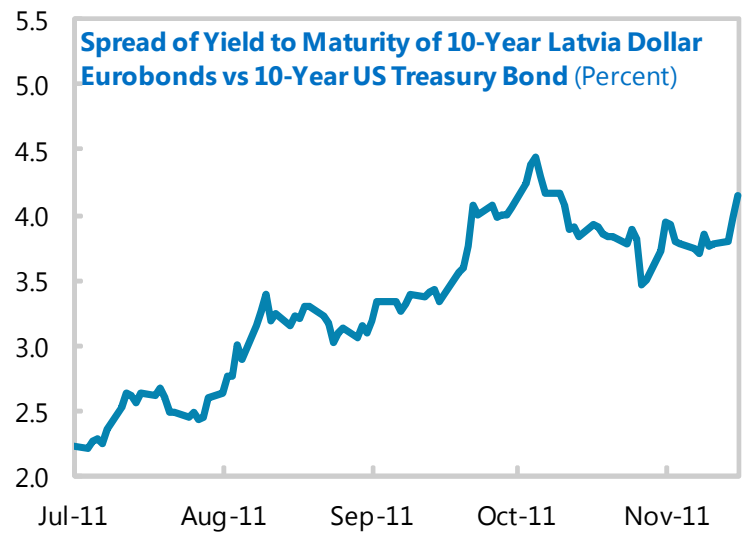

Sources: Bank of Latvia; Bloomberg; and IMF staff calculations. 
Figure 7. Latvia: Banking Sector Developments, 2007-11

Banks have returned to profitability..

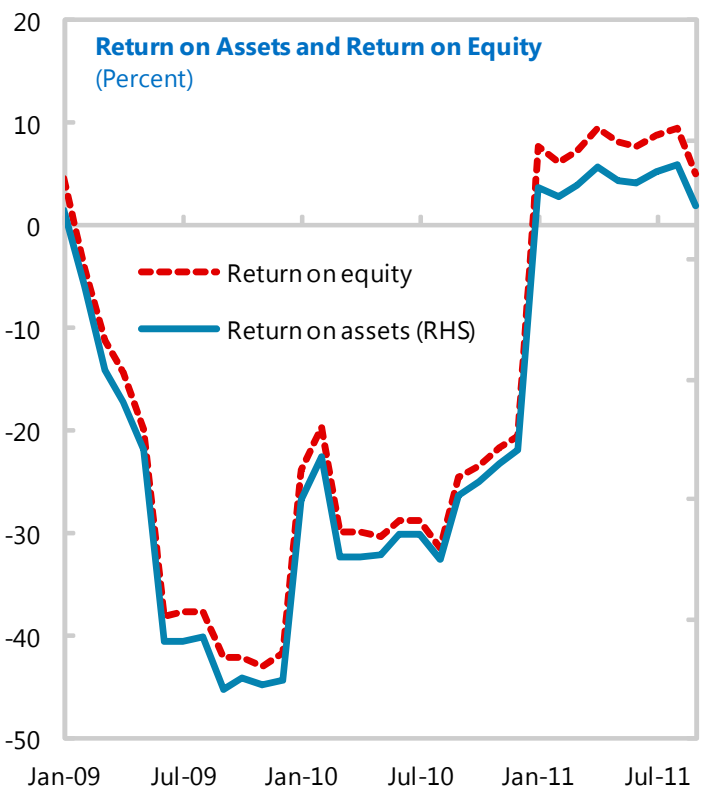

Credit growth remains negative after the bubble ...

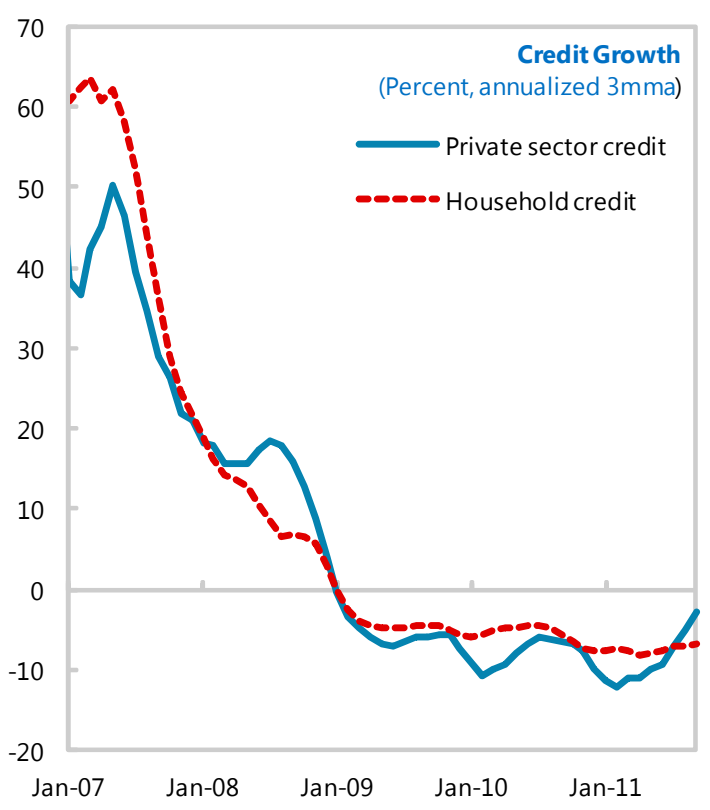

...but overdue loans remain high.

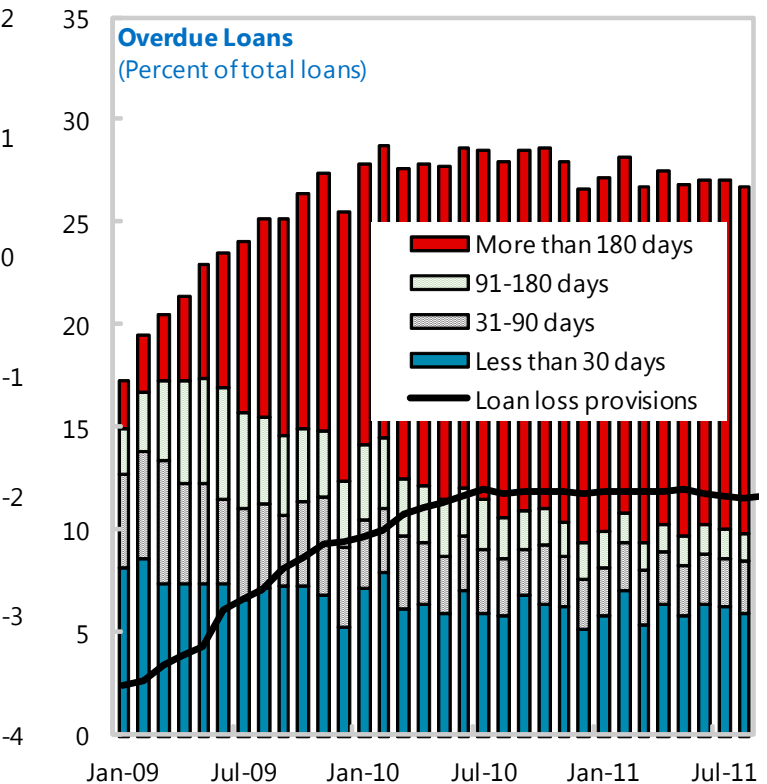

...but the banking system is liquid and money

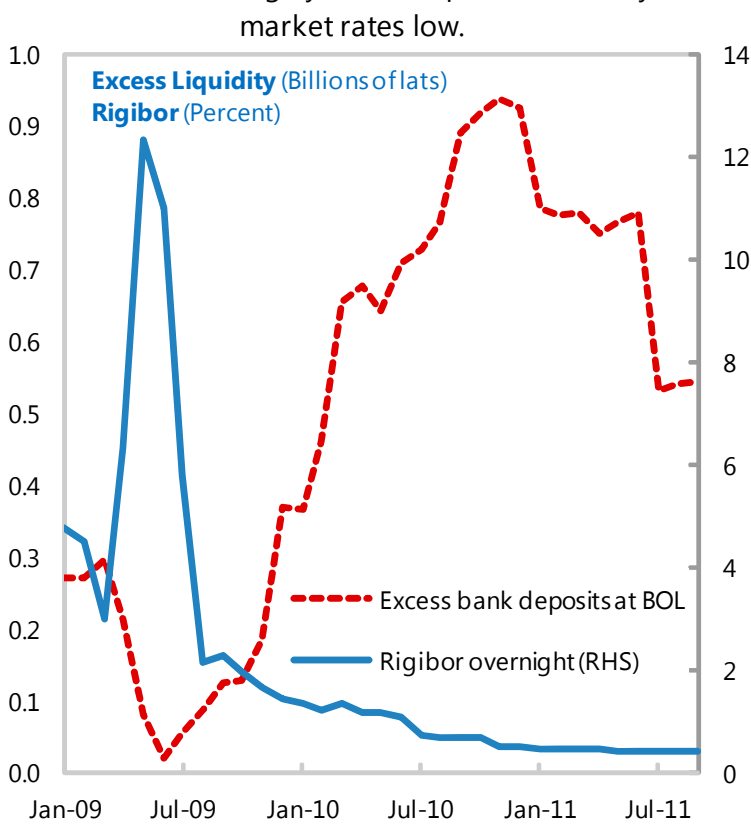

Source: Bank of Latvia; Bloomberg; FCMC; and IMF staff calculations. 
base, is now the single largest party in Parliament (with nearly one third of the seats) but remains in opposition; the party has expressed some reservations about the program.

12. Reform fatigue is increasingly evident. Several political parties made election promises inconsistent with program commitments they had made earlier: Unity's election campaign promised no reductions in pensions (even though many of the increases during the boom had been unfunded) and no increases in taxes (even in residential real estate, whose taxation is less distortionary and which should not increase inflation); Greens and Farmers (Unity's former coalition partner, now in opposition) proposed reintroduction of pension indexation already this year. Resolve for fiscal consolidation is waning, with many hoping that growth by itself will be sufficient to generate future deficit reduction. The composition of the Parliament makes it difficult to secure agreement on structural reforms that require changes to the constitution (two-thirds parliamentary majority needed).

\section{Policy Discussions}

13. Discussions centered on policies that would move Latvia toward euro adoption, implementation of critical structural reforms, and establishing mechanisms that would prevent vulnerabilities from re-emerging. Fiscal discussions centered on a designing a strong 2012 budget that would achieve the program's 2.5 percent deficit target (ESA95) in a sustainable manner, and on a Fiscal Discipline Law (FDL) that would anchor fiscal policy after the program ends. Discussions also focused on completing the much-delayed restructuring of Mortgage and Land Bank (MLB) and on addressing airBaltic's substantial losses, to prevent either from imposing further fiscal costs. The authorities and the staff also started discussions on a framework for post-program surveillance.

\section{A. Macroeconomic Framework}

14. Latvia's economy is recovering, but external shocks are projected to reduce growth next year to around 2.5 percent. The Ministry of Finance argued strongly that growth would be 3 percent or higher, basing this on their discussions with businesses, strong export growth this year, and comparison with projections for other Baltic countries. However, the continued deterioration in the economic outlook for the euro area will likely hurt exports and investment, while indicators of consumer confidence and new orders point to a weakening of domestic demand. The 2012 growth projection is close to consensus, and staff cautioned growth could be even lower, depending on how the euro area crisis was resolved. Slower growth and difficulties reintegrating the long-term unemployed mean that unemployment is projected to decline more slowly, averaging slightly above 15 percent in 2012.

\section{Inflation appears to have peaked, and should decline in 2012. This year's price} increases should raise private sector wages in 2012 (most labor contracts are renegotiated at the end of the year). While this might raise core inflation, the projected decline in international food and energy prices and the lack of direct tax increases should limit headline inflation to around 2.4 percent. Current projections of inflation in other EU countries suggest this could be 
consistent with meeting the Maastricht inflation criterion, although the margin is small and the uncertainty surrounding the forecasts high.

\section{Structural reforms and continued wage restraint are needed to help ensure Latvia remains competitive under its fixed exchange rate:}

- With the scope for further wage and price declines limited, the improvement in competitiveness has slowed, with the CPI-based real effective exchange rates appreciating slightly since mid-2010, and the ULC-based one remaining broadly constant.

- $\quad$ The authorities have implemented some structural reforms that could improve productivity and competitiveness. The World Bank's latest Doing Business Survey suggests that reforms to the insolvency regime, electricity access, property registration, and new business registration have significantly improved Latvia's business environment in 2011, which it now ranks higher than both Estonia and Lithuania. In contrast, the World Economic Forum's global competitiveness report continues to paint a less favorable picture, suggesting that high labor taxes, lack of access to finance, and corruption remain important bottlenecks.

- The authorities have commissioned a group of external experts to prepare a Latvian Competitiveness Report by the end of the year. The report will explore the implications of the shadow economy and income inequality for competitiveness, and should set out a plan for future reforms. The authorities have also committed to strengthen product market competition in their latest SMoU with the EU (including by allocating additional funding to the Competition Council), and have completed a strategy to improve management of state-owned enterprises (end-October benchmark) that, inter alia, aims to separate the ownership function from the management of these enterprises.

\section{B. Fiscal Policy}

17. Despite the surprise bailout of airBaltic (Box 1) and possible costs associated with the liquidation of Krajbanka, the 2011 budget deficit should come in below the 4.5 percent of GDP program target (ESA95). The strong performance of direct taxes and savings from reduced demand for unemployment benefits helped offset the exceptional costs of bailing out airBaltic, the failure of Krajbanka, and financing the sale of the commercial part of MLB. However, spending pressures through the year: (i) on health, social safety net, and road maintenance that were underfunded in the 2011 budget; (ii) to compensate for delays in reforming the system of family state benefits; and (iii) to pay bonuses to stem the outflow of staff from the State Revenue Service (SRS) exhausted the 0.2 percent of GDP contingency reserve, and required new budget appropriations.

18. The authorities' proposed 2012 budget will likely reduce the fiscal deficit to around 2.5 percent of GDP (ESA 95) on a sustainable basis. The government believes that next year's budget deficit will be even lower, at around 2 percent of GDP. However, staff believes 


\section{Box 1. The October 2011 Agreement to Bailout airBaltic}

Unaudited results suggest airBaltic lost around L34 million ( 0.3 percent of GDP) in 2010 and will lose L43 million ( 0.3 percent of GDP) this year. This would have left it with around minus L120 million in equity and negative working capital, despite a L16 million capital injection by the government in 2010. Despite owning 53 percent, a disadvantageous shareholder agreement meant that the state lacked effective control over airBaltic and could not access its books, even as its losses were increasing.

To prevent the airline from collapse, the state agreed in October to invest L16 million (0.1 percent of GDP) immediately and a further L41 million ( 0.3 percent of GDP) before the end of the year, with the private shareholder contributing a further L51 million ( 0.3 percent of GDP). In addition, the company statutes were rewritten to give the state operational control, a new management team has been hired, and airBaltic's structure and business model is being overhauled.

The authorities argued that externalities from airBaltic's role in making Riga a regional transport hub and in attracting tourism justified the state intervention. While an economic case for supporting transport infrastructure might be made, the case for supporting a particular carrier seems much weaker, particularly as airBaltic's lossmaking dominance of Riga airport may have stifled competition. Staff also expressed considerable concern over investing in a company that lacked audited accounts and without an independent business plan setting out a path to profitability, and recommended that these be in place before proceeding with the second tranche of the recapitalization agreement.

The authorities claim that the agreement includes safeguards - including the potential loss of the private shareholder's equity stake in the airline - to give the private shareholder incentives to deliver on its commitments. In particular, they argued that the recapitalization agreement rules out the possibility that state funds will be funneled to the private shareholder (which has previously lent money to airBaltic through a network of subsidiaries) (LOI $₫ 16$ ). However, staff argued that a forensic audit would be necessary, given press reports that past funds had been transferred to parties related to the private shareholder. Staff also argued for making the whole shareholder agreement public - which the authorities were willing to do, as long as the private shareholder agrees - as this transparency would be an effective discipline on the terms of the agreement and would help ensure public money is not wasted. 
that much of this deficit reduction is based on temporary and unsustainable measures: excluding these the deficit would be around 2.5 percent of GDP, although it could be higher if airBaltic requires further bailouts next year. In addition, much of the deficit reduction is achieved through measures such as across the board nominal spending freezes or cuts. These are not of high quality and will have adverse consequences if sustained. While the following categorization is somewhat arbitrary, the measures can be broken down as follows (LOI $\uparrow 11$ ):

- Across-the-board spending restraint (included in the government's baseline). The budget extends the government's nominal wage bill freeze for another year. However, highly qualified staff are already leaving for higher wages in the private sector: such across-the-board cuts risk losing the best performers and complicates the implementation of the authorities' strategy to rationalize the civil service. The budget cuts non-EU financed public investment, which may not be advisable given low levels of national capital spending. Cuts in health spending and road maintenance relative to the 2011 outturn will be difficult to sustain. The government also plans L11 million ( 0.1 percent of GDP) in cuts to the social safety net, including plans to reinstate payments for health services and for overnight hospital stays for those earning L120-150 (€170-215) per month.

- $\quad$ Sustainable measures (L58 million, 0.5 percent of GDP). Planned cuts in agricultural and transport subsidies, and subsidies to Riga Airport, are consistent with past Fund TA and should deliver permanent fiscal adjustment. Some of the measures to broaden the tax-base - expanding the scope of the real estate tax (e.g. to include parking lots), allowing local governments to remove the 25 percent annual cap on real estate tax payments, reverse VAT on scrap metal and construction, and withholding of PIT on scrap metal - are also likely to deliver durable adjustment. The L4 million increase in State Revenue Service funding should help combat the grey economy. ${ }^{1}$

\section{One-off measures; difficult to quantify measures (L51 million, 0.4 percent of GDP).}

These include time-shifts in spending (buying a ship one year early, installing the national library roof one year late) and the tax amnesty (proposed last year but not implemented). These do not yield permanent improvements in the budget. Staff urged that the tax amnesty be combined with the proposed zero declaration of income and assets, so that this might yield some permanent gains in terms of improved tax compliance. ${ }^{2}$ The budget also restricts local government borrowing by L20 million, but unless municipalities are cash constrained, it is not clear how this will translate one-to-one into spending cuts. For example, municipalities with significant deposits may not be constrained at all (Riga municipality intends to repay debts next year); municipalities with fewer deposits may have to cut spending (presumably the poorest).

\footnotetext{
${ }^{1}$ The State Revenue Service has been losing around 1 percent of its staff each month.

2 The zero declaration of income and assets requires tax payers to submit a "zero declaration" of no other income or assets beyond that which has been declared.
} 


\section{Fiscal Measures (millions of lats)}

I. Spending restraint (already in government's baseline)

Nominal freeze in government wage bill

No new central government investment projects, save for EU financed 10

Road maintenance cuts (2011 winter was exceptionally bad, so government's baseline 11

assumes lower spending)

Social safety net (net of increase in health spending) 3

$\begin{array}{lr}\text { II. Sustainable measures } & 57\end{array}$

$\begin{array}{ll}\text { Revenue } & 21\end{array}$

Introduce reverse VAT on scrap metal and construction. $\quad 6$

Broaden real estate tax base to include auxiliary buildings.

Partial elimination of cap on 25 percent annual increase of real estate tax bills 4

Withholding tax on scrap metal (PIT)

Presumptive tax on micro- and small enterprises 3

Gambling: tighter regulation and higher tax $\quad 3$

Double the financial stability levy 2

$\begin{array}{ll}\text { Spending } & 36\end{array}$

Ministry of Defence maintenance $\quad 1$

$\begin{array}{ll}\text { Agricultural subsidies } & 7\end{array}$

Transport subsidies $\quad 5$

Riga airport $\quad 0$

Implementing controls to limit the duration of sick leave 3

Cut local government PIT share from 82 to 80 percent, while maintaining transfers to the $\quad 10$

poorest local governments

Restrict local government borrowing (estimated to result in spending cuts) 10

III. One-off and difficult to quantify measures $\quad \mathbf{5 1}$

Tax amnesty on interest and penalties $\quad 15$

Reduce frequency of tax-free cross border travel (to non-EU) 2

Improved SRS audit coverage $\quad 1$

Restrict local government borrowing (which may not result in spending cuts) 10

Make local governments fully responsible for housing benefit (from May 1) 3

Further cuts in road maintenance $\quad 10$

Cut Ministry of Interior long term liabilities $\quad 1$

Bring forward purchase of naval ship by Ministry of Defence from 2012 to 2011

Delay payment for construction of National Library roof from 2012 to 2013

Shift sport subsidies by one year 1

IV. "Measures" which offset possible additional spending, and so have zero net effect 33

Continue to cap vacation allowances at 25 percent $\quad 8$

$\begin{array}{ll}\text { Continue to cap daily provision allowances } & 19\end{array}$

Freeze at 2011 levels compensation payments to landowners engaged in conservation 6 activities

Source: IMF staff calculations based on data provided by the Ministry of Finance. 
- Measures that take effect in 2013 (L21 million, 0.2 percent of GDP).

The 2012 budget includes a commitment to allow municipalities to raise real estate taxes and to reform the cadastre, and also to reform the system of family state benefits and the social assistance system to improve targeting and reduce poverty traps. It also envisages continuing to limit parental, unemployment, and sickness benefits, while continuing to cap replacement rates of maternity and paternity benefits at 80 percent.

\section{Staff expressed concern at the quality of the budget and the lack of sustainable measures:}

- $\quad$ The authorities were unwilling to prepare and organize discussions around a no-policy-change fiscal baseline, and only partially prepared a detailed menu of options to close the fiscal gap (end-August structural benchmark).

- $\quad$ The budget includes few structural reforms, relying mainly on across the board spending cuts, revenues from the grey economy, and numerous one-off effects to reduce the deficit. This might be justified in the middle of a crisis, where it takes time to prepare and win support for structural reforms. But almost three years into the program, staff argued that the focus increasingly should be on sustainable adjustment that will help Latvia meet the Maastricht criteria, and fulfill its medium-term fiscal objective of close to budget balance. This would also help limit financing risks.

- The authorities refused to discuss tax increases, even though reform of the cadastre and increase in the residential real estate tax rate have long been on the program agenda. Progressive personal income tax was also not discussed.

- $\quad$ Savings from pensions (while making sure poor pensioners would not be worse off) were also ruled out, even though the average pension for new retirees had increased almost 70 percent in real terms from 2005 to 2009, and failure to implement pension reform has been identified as the biggest shortcoming of the government's crisis policy. ${ }^{3}$ Improved targeting of social assistance and social benefits might also yield savings.

- A relatively large part of the adjustment burden is being borne by local governments, where capacity for savings is harder to monitor and where the poorest municipalities may already face difficulties financing safety net spending.

- Unlike recent years, the contingency reserve is minimal, so ministries will need to keep a much firmer grip on spending if the government is to meet the deficit target.

\footnotetext{
${ }^{3}$ Aslund, Anders and Valdis Dombrovskis (2011), "How Latvia Came Through the Financial Crisis", Peterson Institute of International Economics, p109.
} 
20. The government disagreed with this assessment, arguing that their budget was based on conservative assumptions and would deliver the necessary adjustment, or even more. They argued that evidence to-date suggested their strategy to combat the grey economy would yield significant additional revenues, and that the freeze of the nominal wage bill and cuts in capital, health, and maintenance spending were sustainable because of the government's strong commitment to the deficit target. They also suggested that the pressure of meeting the spending limits would encourage structural reform, and stressed their commitment to pass a supplementary budget in 2012 if required to meet the target. Indeed, Governor Rimšēvičs has cautioned that the current budget lacks sufficient contingencies to deal with the possibility of recession in Europe, and that more measures will be needed in the first half of 2012.

\section{Staff urged the authorities to resist further cuts to an already-stretched social}

safety net. Job creation remains weak, poverty rates are high compared to other EU countries, and an increasing share of the unemployed have been out of work for more than 9 months so they no longer qualify for unemployment benefits (Box 2). Weak labor market prospects are causing emigration, which is likely much higher than reported by the official statistics. Also, even though the authorities intend to cut it, demand for the Workplace with Stipend (WWS) program remains high, especially in regions with high unemployment and poverty. To meet these increasing demands, staff argued that the social

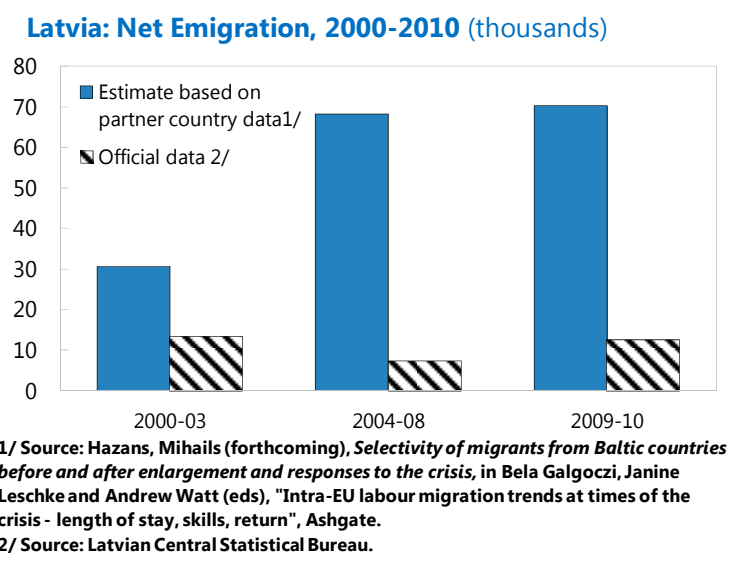
safety net should be strengthened by merging it with the system of social assistance and by centralizing and improving the targeting of the now-universal guaranteed minimum income (GMI), while reforming the system to avoid poverty traps. The authorities disagreed, arguing that the social safety net should be phased out now that the crisis was over, and that responsibility for providing welfare ("eating, heating, and housing") should be decentralized to municipalities, as it was before the crisis. However, after extensive discussion, the authorities agreed to continue to co-finance

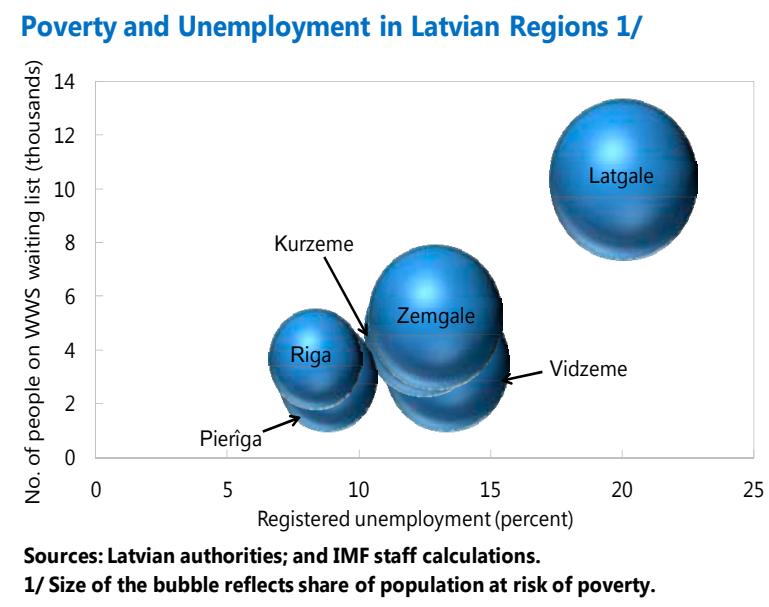
50 percent of the cost of GMI in 2012 (though they would cease co-financing housing benefit from May) and to prepare a strategy for reforming the entire system of social assistance in 2013 (LOIף11). 


\section{Box 2. Poverty and Inequality in Latvia}

Latvia is one of the poorest countries in the EU. Even before the crisis, almost 36 percent of Latvia's population was classified as being at risk of poverty and social exclusion, and average real GDP per capita (PPP terms) stood at around 50 percent of the EU average.

The 2008-10 economic crisis exacerbated the poverty problem. Average real income per capita declined by about 19 percent and the share of the population at risk of poverty increased by 1.4 percentage points. Income inequality deepened - the richest 20 percent of the population earn seven times more than the bottom 20 percent - and is now one of the highest in the EU.

With crisis-related increases in the social safety net system about to expire, Latvia needs a comprehensive reform of the social safety system to improve incentives to work and help address poverty traps. Currently only 1.6 percent of all social assistance expenditure is means-tested (i.e. GMI and housing benefits), which is less than half the 3.4 percent EU average. In addition, in the existing system assistance is only provided if a recipient's income falls below a certain threshold (L40 per person, plus L45 per child). Therefore, a beneficiary whose income exceeds this threshold loses GMI assistance, and is likely to lose housing benefits as well if family income exceeds L120 to L150 (depending on municipality). Such benefit design may discourage employment, especially in low paid jobs, and may divert jobs to the grey economy.

Changes to the tax code can encourage job creation and promote legal employment. High labor taxes mean that job creation in Latvia is very costly. In 2009, the tax wedge was almost 42 percent, which is close to the euro area average, but higher than in other new member states. Finding employment does not bring many advantages to the unemployed either; in 2010, the unemployment trap (the amount of gross earnings taxed away though higher taxes and social security contributions, and through a withdrawal of unemployment and other benefits) stood at 90 percent, the second-highest in the EU. Low-wage earners in Latvia, especially single-earner families with children, are also heavily penalized as their income increases; in 2010 the low wage trap (the percentage of earnings taxed away as gross earnings increase from 33 to 67 percent of the average wage) stood at 79 percent, the seventh highest in the EU.

Staff discussed the need to reform the social safety net system with the authorities. Centralizing funding of the GMI system would ensure equal access to benefits across all regions, making sure poorer regions have the ability to pay, while a gradual reduction in benefits as income rises would increase incentives to work. Staff encouraged the authorities to increase the share of means-tested benefits by reforming the family state benefit system (including child and parental benefits). Tax code reforms, such as shifting taxes from labor to immovable assets (such as real estate), introducing tax allowances for firms that create new work places (on a net basis) could also be considered. The authorities initially proposed to decentralize the administration and funding of the GMI (against World Bank advice) but agreed to postpone this change for a year while conducting a comprehensive evaluation of the social safety net and social insurance schemes, which will form the basis for a reform of social assistance in 2012. 


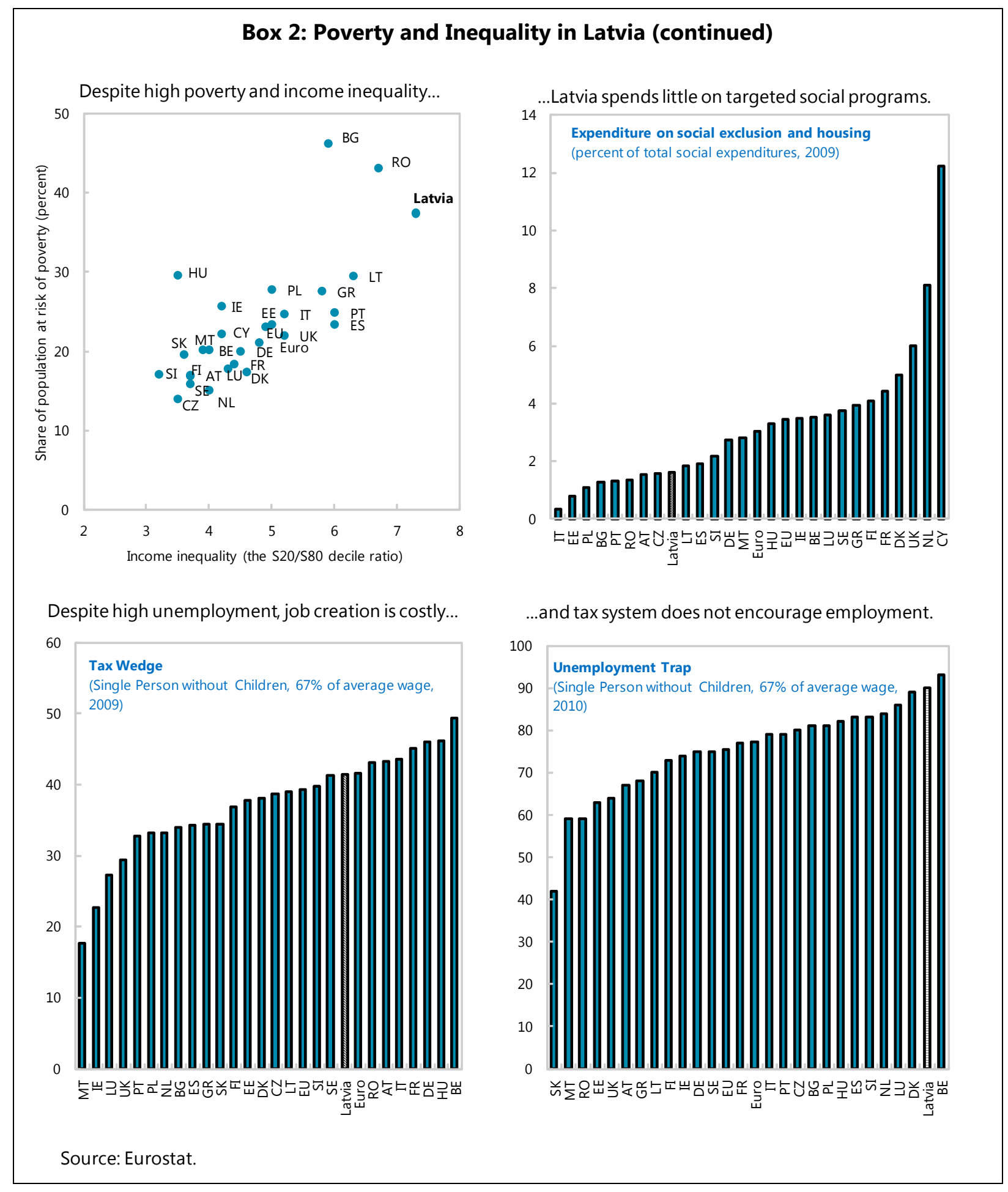




\section{The collapse of Bank Snoras (in Lithuania) and Latvijas Krajbanka (Latvian Savings Bank) undermines the viability of the agreement to bailout airBaltic (Box 1).}

- The airline has loans outstanding to both banks, and the banks' representatives - who are under criminal investigation - are signatories to the bailout agreement. Moreover, Snoras and Krajbanka are important financial backers of Baltijas Aviācijas Sistēmas (BAS), the private shareholder in airBaltic. Given the discovery of fraud in these banks, staff questioned the appropriateness of the bailout agreement, and noted the increased risks that the private shareholder may not pay the second tranche of its investment (L37.7 million).

- Staff suggested that the Legal Protection Procedure (LPP) in the new bankruptcy law, which includes an automatic stay on creditor action, might be the least costly and most effective way to stabilize airBaltic's financial position and secure its survival. They urged the authorities to take legal and financial advice on this option. However, the authorities argued that LPP would likely trigger default clauses in agreements with suppliers and that it would be difficult to get a sufficient majority of creditors to vote in favor of a restructuring plan.

- Instead, the authorities have taken full control of the airline, taking over the private shareholder's shares that were pledged to Latvijas Krajbanka. The bailout agreement remains in force, however, and the private shareholder may recover its stake in the airline if it injects more money later this year. Until then, the state is liable for all airBaltic's debts, including to Bank Snoras and to related parties (for example, airBaltic's subsidiaries). It is hard to estimate these costs, but on the assumption airBaltic remains outside general government (as seems likely under ESA95 rules) they could raise the budget deficit by an additional 0.27 percent of GDP and net debt by up to 0.7 percent of GDP (over and above what is in the original agreement). Future losses could also raise the deficit. The authorities will try and book these losses this year to not complicate their goal of meeting the Maastricht fiscal criterion in 2012. However, this may raise concerns over whether the criterion has been met on a sustainable basis. In addition, under full state ownership, the bailout of airBaltic needs to be consistent with EU state aid rules.

\section{The authorities have submitted a Fiscal Discipline Law (FDL) to Parliament to} anchor fiscal policy after the program ends. It includes a countercyclical fiscal rule that entails a balanced budget over the economic cycle, and is consistent with the EU's Stability and Growth Pact (SGP). However, the authorities recognize that for this fiscal framework to be fully effective, constitutional changes are necessary to ensure the FDL has primacy over other laws, notably the annual budget law. The government will need to build consensus for this approach, given that the coalition lacks the necessary two-thirds majority in Parliament. Though delayed, the authorities also intend to submit to Parliament a medium-term budget framework law (MTBFL) as soon as the FDL is passed. The MTBFL will subsequently set binding multiannual 
expenditure ceilings, and limit the possibility of introducing expansionary fiscal measures after the annual budget has been adopted.

\section{Financial Sector Policies}

\section{The FCMC decided in late-November to freeze all operations (including all} deposits) of Latvijas Krajbanka, to replace its management, and liquidate the bank.

- $\quad$ The decision to intervene the bank - which accounts for 3 percent of banking system assets and 5 percent of total deposits, with a large rural deposit base-was taken after the discovery of fraud in the bank (L100 million in foreign assets thought to be unencumbered turned out to be pledged as collateral). This was discovered after an earlier decision by the Lithuanian government to take over Snoras Bank (Krajbanka's parent bank). After failing to find any buyers for Krajbanka's assets, the FCMC filed for Krajbanka's insolvency; insured depositors are being reimbursed via Citadele Bank. The problems in Krajbanka have also prompted the head of the FCMC to step down.

- $\quad$ Funds in the Deposit Guarantee Fund and Krajbanka's liquid assets have been supplemented by a L200 million Treasury Loan to ensure prompt payment to all insured depositors. ${ }^{4}$ The authorities have assured staff that the resources available in the Deposit Guarantee Fund (including the future stream of banks' contributions to the Fund), coupled with the proceeds from the liquidation of the bank, will be sufficient to repay this loan. Local governments or government agencies (e.g. state universities) with deposits in Krajbanka have also received Treasury loans to allow them to continue operations. While government debt will increase and the Deposit Guarantee Fund may need replenishing, the authorities argue that the intervention in Krajbanka will not increase the fiscal deficit. This seems correct, provided that non-guaranteed private deposits are not compensated.

- While fraud can be extremely difficult to detect, and losses seem smaller than in Bank Snoras, Krajbanka's problems point to deficiencies in supervision. The FCMC had been warned earlier about possible problems in Krajbanka, and had placed its own staff to oversee the bank and approve large transactions, yet these staff had failed to detect problems. When the crisis broke, the FCMC did not request Fund assistance or seek outside advice, and the decision to freeze deposits was done in an unpredictable manner - at first too loose and then unnecessarily harsh. Although the FCMC did make an unsuccessful attempt to sell the bank's assets, it did not use new legislation introduced under the program that would allow separation of Krajbanka into a good and bad bank, and then to transfer the good bank to another bank. They argued that existing legislation did not allow the forced transfer of assets and liabilities, and that banks

\footnotetext{
${ }^{4}$ The Deposit Guarantee Law guarantees repayment of deposits up to $€ 100.000$ within 20 days from the unavailability of deposits, although this can be extended by 10 days if necessary.
} 
would require too much time to verify the quality of Krajbanka's assets and therefore chose instead to pay out deposits and liquidate the bank, a strategy which staff believes is unlikely to maximize recoveries.

\section{The government finally approved its sales strategy for MLB, and submitted it to the EC on November 2 (LOI q23):}

- During April's Fourth Review the authorities had committed to submit their sales strategy to the EC by end-June (structural benchmark) and to complete the sale by midDecember (structural benchmark). However, concerns over the amount of state aid needed to complete the transaction, the late hiring of a sales consultant, and September's unexpected parliamentary elections have caused delays. Despite these delays, the authorities are starting the sales process this year (initial bids are due late-December) and plan to sign final sales agreements by end-March 2012.

Though there is a risk that the EC's DGCOMP will launch an investigation into the possible misuse of a loan from the Nordic Investment Bank in the last recapitalization of MLB in April 2010, the authorities assured staff this would not affect their plans to sell the commercial part of the bank. The investigation itself will take some time (possibly a year), and so should not directly impact the sales process. However, the investigation could cause potential investors to act more cautiously.

- $\quad$ The authorities' sales strategy — developed by independent consultants - is broadly consistent with the restructuring plan submitted to the EC in April, and envisages selling bundles of MLB's commercial assets and liabilities (including nearly all deposits) in a two-step auction. All commercial assets will be offered for sale, but those in which there is little or no market interest (e.g. the subsidiary which manages MLB's non-performing assets) are likely to be transferred to the Latvian Privatization Agency and managed by Parex for a more gradual workout.

- The authorities have prepared a communication strategy to reassure the public and maintain depositor confidence during the sales process, and substantial contingency liquidity from the Treasury is available. A contingency plan is also being developed if the bundles that include MLB's deposits are not sold, to ensure these are divested in a manner which maintains financial stability. 
- Staff welcomed the adoption of the sales strategy, and urged the authorities to implement it quickly, so that the fiscal costs associated with past losses in the bank could be recognized upfront. ${ }^{5}$

- Staff encouraged the authorities to remove MLB's banking license once the sales process was completed, so that the remaining development part would not have the opportunity to expand deposits and create new fiscal risks. The authorities disagreed, arguing that the few remaining deposits - around L10 million from clients of the development bank - were integral to the operation of the development bank. They also did not want to prejudge the outcome of their strategy for the consolidation of development lending institutions, which should be completed by mid-2012. ${ }^{6}$

\section{The sale of Citadele Bank is scheduled to be completed early next year.}

- Initial bids were received in late October and a second round of bids is expected in December. The authorities recognized that recent market turmoil could lower bids, but noted that the M\&A market in CEE countries has held up relatively well.

The authorities were surprised at Moody's recent decision to put Citadele on review for a possible downgrade. They acknowledged that the bank's asset quality was lower than when the sale was launched and that capital levels were declining, but argued these developments had been anticipated in their (EC-approved) restructuring plan. They reiterated their commitment to keep Citadele adequately capitalized until sold, and to provide additional state aid (in the form of liquidity, capital, and/or guarantees) if necessary during the sales process.

\section{The authorities intend to remove Parex's banking license and transform it into a special purpose vehicle (SPV) to let it focus on asset management (LOIV|26). This would} free Parex from regulatory requirements such as minimum capital requirements, provisioning according to banking regulations, and deposit insurance contributions, and reduce operating costs and increase returns to the State. The authorities also agreed to put in place formal targets for Parex management, and to require Parex to make periodic distributions to the State Treasury to prevent Parex from squandering recoveries by inefficient operations.

\footnotetext{
${ }^{5}$ Based on discussions with Eurostat, ESA accounting rules allow the authorities to record the fiscal costs associated with restructuring MLB when a clear decision is made to restructure the bank, even if the transaction is completed later.

${ }^{6}$ Approval of the development institution strategy has been repeatedly delayed. Independent consultants prepared an initial strategy back in February 2010; in the last LOI and SMoU the authorities agreed to approve a strategy by end-October 2011 for setting up a single development institution. This has now been pushed back to mid-2012 and creation of the development institution will take even longer.
} 
28. The authorities argued that a court ruling overturning a legal provision used to resolve Parex did not undermine their ability to intervene ailing banks. The Constitutional Court ruled in October that the legal provision used to forcibly recapitalize Parex in 2008 was unconstitutional because it violated existing minority shareholders' property rights. However, since the Court's decision is not retroactive, it does not undermine current efforts to resolve Parex and Citadele. Extensive discussions reassured staff that the authorities still had sufficient mechanisms at their disposal - including Purchase and Assumption (P\&A) transactions, the ability to replace management, and nationalization - to resolve ailing banks in the future. Staff also welcomed the authorities' progress in pursuing Parex's former shareholders and senior managers in the courts for losses they caused to Parex and to the State.

29. The failure of Latvijas Krajbanka highlights the need for stronger supervision of the financial sector. The quality of financial regulation in Latvia has improved over the program period. However, the authorities agreed that the failure to uncover the fraudulent activities in Latvijas Krajbanka at an earlier stage suggested the financial regulator's capacity to supervise the financial system needed to be further strengthened. To that end, the authorities have committed (LOI $\mid 22$ ) to introduce amendments which make it criminal for banks to submit distorted or incomplete information to the FCMC and to strengthen the FCMC's capacity to conduct forensic investigations. The authorities also agreed to require Latvian banks to hire external auditors to verify that all encumbered assets in banks' correspondent and securities accounts are properly reported (unlike the cases of Latvijas Krajbanka and Bank Snoras), and properly valued.

\section{Debt Restructuring}

30. Staff welcomed the authorities' intention to address the problem of unpaid utility bills, while not undermining the status of secured creditors (LOI 929). The authorities have withdrawn amendments to the Civil Procedures Law (end-July structural benchmark) that would have retroactively granted priority status in foreclosure proceedings to utility companies' unsecured claims. Instead, they have prepared a strategy to address the problem more directly, including by introducing a new credit scoring registry with information on debts to non-banks (including utility companies) and reducing court and bailiff fees for small claims. Recently introduced streamlined procedures for small claims (up to L1,500) should also make it cheaper and faster for utility companies to recover their debts.

\section{E. Monetary Policy}

31. Given the fixed (narrow band) exchange rate peg to the euro, staff encouraged the authorities to harmonize their policy making with the ECB. Staff questioned the negative interest rate differential between BoL and ECB policy rates - the BoL's overnight deposit rate remains 25bps below the ECB's deposit rate despite the ECB's recent 25bps cut, the interbank rate differential is higher-given the nearly $€ 770$ million decline in international reserves between October 2010 and April 2011. Aligning policy rates with the ECB's would demonstrate 
the BoL's commitment to the constraints on monetary policy implied by the fixed exchange rate, and would signal its readiness to join the euro area. The BoL accepted that it would be desirable to gradually harmonize policy rates with the ECB to eliminate arbitrage opportunities, but downplayed the impact of the interest rate differential; it explained the earlier decline in reserves as the result of foreign banks' natural deleveraging (since the beginning of the year, foreign-owned banks have reduced their liabilities to parent banks by approximately $€ 1.1$ billion). Although reserves have since recovered as a result of June's US\$500 Eurobond and large inflows of EU structural funds, staff still saw further outflows as likely as long as the return on short-term lats assets is below that of equivalent euro assets.

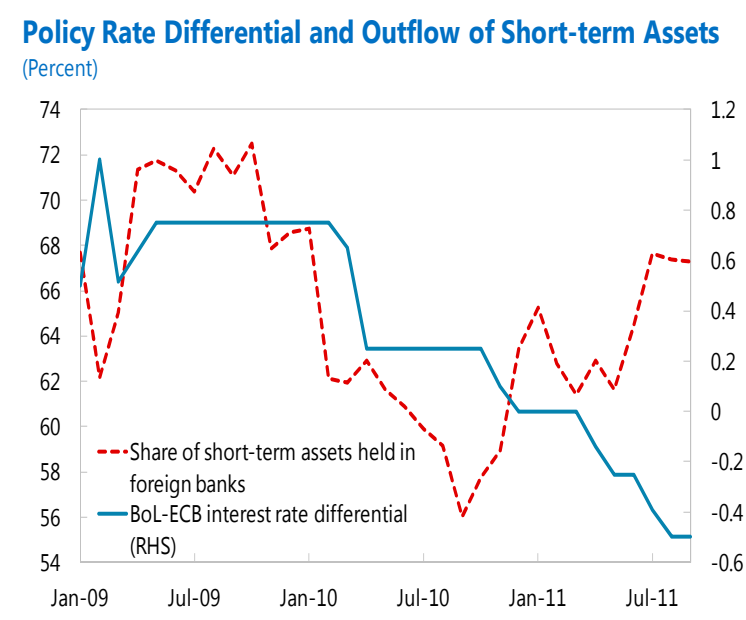

Sources: Bank of Latvia and IMF staff calculations.

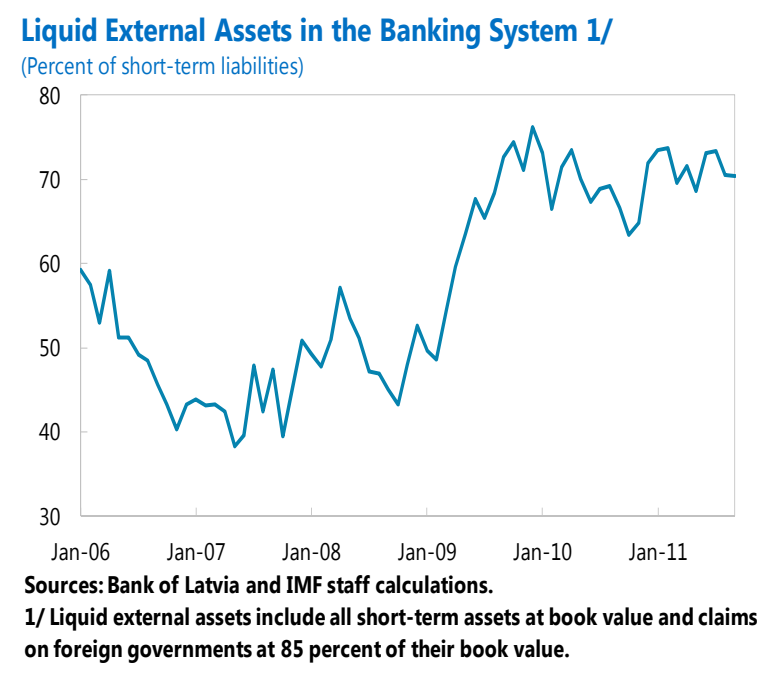

\section{Program Issues}

32. Latvia met all quantitative performance criteria for end-August, as well as the endJune and end-September indicative targets, and is on track to meet the indicative targets for end-2011 (LOI Table 1). Former President Zatlers' unexpected decision in early June (two weeks after the Fourth Review Board meeting) to seek Parliament's dissolution, together with the subsequent referendum and parliamentary elections, delayed progress on many of the structural benchmarks, although most have now been met (LOI Table 3). The authorities have made LOI commitments to implement those structural benchmarks that have not been metincluding sale of the commercial part of MLB - in 2012. Staff supports the authorities' request for a waiver of nonobservance of a continuous performance criterion resulting from the decisions in late November to freeze all deposits in Krajbanka, on the basis that this was temporary (the bank is now being liquidated and insured depositors are being repaid). ${ }^{7}$

\footnotetext{
${ }^{7}$ The deposit freeze under the November 2011 decisions gives rise to an exchange restriction subject to the Fund's jurisdiction, as it prevents non-residents from transferring abroad payments received from current international transactions.
} 
33. Given their comfortable financial position, the authorities do not intend to draw the amounts available at this review, and will only draw $€ 100$ million available from the World Bank. The amounts available from the IMF, EU, and bilateral funds will be treated as precautionary (Table 14).

34. Latvia is expected to be in a comfortable position to repay the Fund, provided there is not a dramatic deterioration in international financial markets (Table 15). Outstanding Fund credit is projected to reach about 21 percent of gross reserves in 2011 with repayments peaking in 2013 at 2.3 percent of GDP and 8 percent of gross reserves. Gross external debt is projected to fall steadily from its 2010 peak of around 165 percent of GDP. Net external debt is substantially lower (49 percent of GDP at end-June 2011) and falls over the medium-term (Tables 7-8 and Figure 9). With only $€ 4.1$ of the original $€ 7.5$ billion financing program drawn (and only $€ 1.1$ used of the $€ 1.7$ billion made available by the Fund) Latvia's repayments to the Fund are considerably lower than anticipated when the program was launched and during the first year of the program, and Latvia's capacity to pay should be comfortable unless further intensification of the euro area crisis complicates plans to tap capital markets.

\section{The authorities and staff have agreed on a strong framework for continued} engagement by the Fund and the EC after the program ends. In light of the amount of outstanding Fund credit, the Managing Director recommends that Latvia engage in Post-Program Monitoring of economic developments and policies until outstanding Fund credit falls below 200 percent of quota (December 2013). Staff and the authorities will discuss policies regularly, and will formally report to the Executive Board twice a year. The Fund will closely coordinate with the EC's Post-Program Surveillance efforts. The Fund will also conduct an ex post evaluation of exceptional access under the current SBA within a year after the end of the arrangement. In accordance with Executive Board Decision No. 14747-(10/96), Latvia shall be placed on a 12-month consultation cycle for Article IV consultation given that it currently has an outstanding Fund credit exceeding 200 percent of quota.

\section{RISKS}

36. Implementation of the program has strengthened Latvia's ability to withstand shocks, but risks remain:

- The uncertain external environment, especially tensions in the euro area, is an important downside risk given Latvia's real and financial sector linkages to Europe (though direct links to the euro area periphery are few). Exports and economic growth could decline more than expected if the external environment continues to deteriorate, and intensified financial turmoil in the euro area could spill over to Latvia through a repatriation of assets by Swedish banks and outflows of nonresident deposits. A dramatic worsening of the euro area crisis could lead to more fundamental challenges for Latvia, and points to a need for contingency planning. 
- The new government coalition is fragile, with only a narrow majority. This could constrain the government's ability to maintain fiscal discipline and to secure support for contentious structural reforms.

- $\quad$ Fiscal and structural reforms are needed to support a smooth functioning of the economy under the fixed exchange rate. Although fiscal adjustment to-date has been unprecedented (especially when compared to other crisis countries in Europe), this now needs to be followed by reforms to fiscal institutions to sustain this adjustment, and to avoid a return to pro-cyclical polices. Structural reforms and productivity improvements are essential to maintain competitiveness under the fixed exchange rate or in the euro area. Also, the sharp upward revision of the 2010 ESA deficit (from 7.7 to 8.3 percent of GDP due, among other things, to a revaluation of assets in the State Real Estate Company) is an example of a large ex-post change in the ESA deficit that demonstrates the importance of a safety margin for meeting the Maastricht deficit criterion.

To reassure depositors and to maintain financial stability, the liquidation of Krajbanka and the sales of Citadele and the commercial part of MLB need to be managed carefully. The political will to complete these transactions could diminish if bids are lower than anticipated, and there could also be a need for further state aid to keep these banks compliant with regulatory requirements. If the authorities fail to meet their commitment to prevent MLB from attracting new deposits once the commercial assets and liabilities are sold, there is a risk that the bank could later re-emerge as a threat to financial stability and source of fiscal uncertainty.

- $\quad$ There is a risk the fraudulent activities in Latvijas Krajbanka might be present in other banks. Making sure that the financial sector is properly audited is essential to maintaining confidence and avoiding further bank failures and any repeat of the sharp decline in deposits and reserves seen in 2008-09.

- There are risks that airBaltic will require more government bailouts if efforts to restructure the airline prove unsuccessful, that public funds injected into the company might be used to bail out the private shareholder, or that as sole owner of the airline the Latvian state becomes liable for all airBaltic's debts. More generally, the problems in airBaltic point to problems in state enterprise governance and the risk of uncovered losses that in the end the government will pay. 
- $\quad$ Financing risks. Latvia needs to issue relatively large amounts of bonds (compared to recent transactions involving CEE countries) to be able to make large repayments to official creditors in 2014 and 2015. Latvia's low public debt level and improving credit rating suggests this may be feasible, particularly if it can join the euro area (as domestic debt would be issued in euros and so become

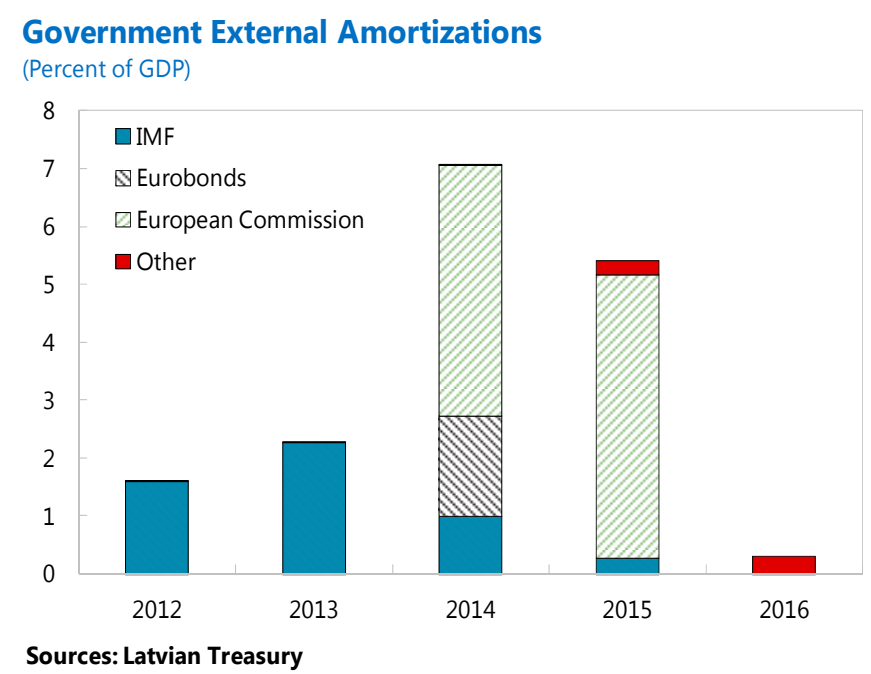
more attractive to investors), but turmoil in international capital markets suggests prefinancing or early repayments may be prudent. The authorities are mindful of these risks and are discussing their debt management strategy with Fund staff.

- Current uncertainty and tensions in the euro area could risk delays in Latvia's euro adoption. This would lower confidence and perpetuate exchange rate risk, and could have a detrimental impact on policy making.

\section{STAFF APPRAISAL}

37. Though the economic recovery is continuing, growth is expected to slow next year as external demand weakens. Despite continued fiscal consolidation, domestic demand has started to recover and growth this year should reach 4.5 percent or even higher. However, for the coming year, the deteriorating external environment will likely result in lower export growth, and some slowdown in the economy. With the rise in world food and energy prices easing, inflation should decline toward levels consistent with meeting the Maastricht criteria. However, unemployment remains high and the share of long-term unemployed has risen to roughly one half. And while the financial sector has resumed lending, especially to the corporate sector, credit growth remains weak and is increasingly a drag on economic activity.

\section{Despite recent slippages, program performance since the last review has been} satisfactory, although structural reforms have been delayed. Stronger than expected revenue collection, coupled with fewer unemployed being eligible for benefits, should offset spending overruns in some areas (health spending, the bailout of airBaltic, costs associated with the sale of MLB) and allow the authorities to meet their end-year deficit target. The BoL should meet its NIR and NDA targets with comfortable margins. However, the authorities will need to expand their international borrowing program and build up international reserves, so as to be able to repay the Fund and international creditors. The unexpected parliamentary elections delayed structural reforms, although a critical mass of structural benchmarks (including preparation of 
a 2012 budget consistent with the program, submission of a FDL to Parliament, and submission of an MLB sales strategy to the EC) have now been completed.

\section{Although there are few structural reforms in next year's budget, it is likely to}

deliver a deficit below 2.5 percent of GDP (ESA95). Many of the budget's measures - an across the board freeze in nominal wages, cuts in central and local government investment, cuts in road maintenance - are of questionable quality. Cuts in social safety net spending seem inadvisable given the increase in long-term unemployment and over-subscription for public works programs (which the authorities still intend to cut). Alternative measures, such as higher real estate taxes and improvement of the cadastre, progressive personal income tax, and improved targeting of social benefits, might have proved less distortionary and made the fiscal adjustment more equitable. While across the board cuts might be unavoidable early on in the program, now that the crisis is over the fiscal consolidation should have been based more on structural reforms. This would have been easier had the government prepared and debated a full menu of fiscal options (end-August benchmark), and used this for the budget. However, this year's budget should be viewed in the context of the around 15 percent of GDP in fiscal consolidation that Latvia has already implemented during the program, and the improvement in debt sustainability that has resulted. And despite its shortcomings, the budget is likely to deliver a deficit target in line with the program target and should meet the Maastricht criteria for euro adoption, the authorities' goal after the program ends.

\section{The BoL should harmonize its policy making with the ECB to support the fixed} exchange rate. The negative interest rate differential with the ECB is hard to justify given the peg to the euro. Harmonizing policy rates would eliminate simple arbitrage opportunities and should help stem the loss of reserves. It would also demonstrate the BoL's preparedness for monetary policy being determined by the ECB, and for admission to the euro area.

\section{The authorities should complete the orderly sale of the commercial part of MLB} and Citadele. Though much delayed, the authorities' submission to the EC of a strategy for selling the commercial assets and liabilities of MLB is welcome. They now need to maintain the resolve to recognize losses in full and proceed with the sale of both the commercial part of MLB and Citadele without undue delay, while maintaining depositor confidence. Once the commercial parts of MLB have been sold, the remaining development part should be merged into a single development institution, and prevented from restarting deposit-taking activities and becoming a future source of fiscal and financial stability risk. In staff's view, removing the remaining development bank's license would have been the surest way to do this.

42. While intervention in Latvijas Krajbanka was warranted, it highlights the need for stronger supervision of the financial sector. Failure to detect problems in Krajbanka despite earlier warnings which had prompted the FCMC to place supervisory staff on-site points to weaknesses in supervision. Failure to use new legislation to quickly transfer Krajbanka's assets and liabilities to another financial institution points to weaknesses in crisis resolution. The FCMC's move to quickly give depositors access to their insured deposits is welcome, but its 
choice to liquidate the bank is unlikely to maximize recoveries. Given Latvia's role as a financial centre and its extensive non-resident deposits, the government should require the financial regulator to make sure that the problems in Krajbanka are not more widespread, through independent and thorough verification of the quality of banks' capital and of the value and encumbrance of bank assets.

\section{The costly bailout of airBaltic illustrates the need to improve governance in state-} owned enterprises, and of determining which firms should be privatized. Management's ability to run large losses reflects severe governance problems and poor oversight by the State and the supervisory board. The authorities should undertake a forensic audit to understand the sources of these losses and to make sure public funds have not been misused. The staff has considerable doubts over whether the new shareholder agreement will be strong enough to solve airBaltic's governance problems and return it to profitability, especially given complications arising from the alleged fraud in Krajbanka and its subsequent failure. However, nationalizing the company could increase fiscal costs if it were to make the state liable for airBaltic's debts and future losses. Although the authorities may be able to include these costs in the 2011 fiscal accounts, it does raise questions over whether the authorities' fiscal consolidation is sustainable. These developments underlie the importance of not just developing a strategy to improve management of state-owned enterprises (an end-October structural benchmark), but also of implementing it.

\section{Over the course of the program, the authorities have stabilized the economy and} introduced numerous structural reforms. The exchange rate peg has held, the current account deficit has moved into surplus, international reserves have been replenished, interest rates have fallen, and the economy is in its second year of recovery. Fiscal consolidation of more than 15 percent of GDP has lowered the deficit back toward the Maastricht criterion and restored debt sustainability. Consolidation has been backed by structural reforms, including the streamlining of public administration (abolition of half of state agencies; large reduction in civil servant numbers); health sector reform (shift from overspending on hospitals and beds to outpatient and preventive care); and education reform (school closures and teacher layoffs; introduction of "money follows the student" principle). Financial regulation and supervision has also improved significantly.

\section{Looking ahead, the authorities need to implement reforms that will safeguard these} achievements and prepare Latvia for successful euro adoption. In the short run, this means meeting the Maastricht criteria (including being ready to adopt a supplementary budget in the first half of 2012 if necessary), and putting in place contingency plans to prepare for a possible worsening of the euro area crisis. For the medium term, this means passing a strong FDL with a countercyclical fiscal rule and lowering the budget deficit toward the medium-term objective of a balanced budget over the cycle to reduce financing risks and prevent a recurrence of the boom that led to the crisis. This should be supported by constitutional amendments to make the FDL effective, and a Medium Term Budget Framework. Latvia should also implement the structural reforms outlined in their SMoU with the EC to enhance productivity and efficiency, to make 
sure that competitiveness does not again become a problem under the fixed exchange rate regime or after adopting the euro. These topics will be the focus of post-program monitoring by the Fund and the EC.

46. Despite recent slippages, Latvia's performance under the Fund-supported program has underpinned a return to economic growth and a decline in vulnerabilities. Staff supports the authorities' request for completing the Fifth Review and financing assurances review on the basis of Latvia's performance under the arrangement, and the policy commitments specified in the Letter of Intent. Staff also recommends granting a waiver of nonobservance of the continuous performance criterion due to the temporary imposition of an exchange restriction subject to the Fund's jurisdiction. 
Table 1. Latvia: Selected Economic Indicators, 2008-12

\begin{tabular}{|c|c|c|c|c|c|c|}
\hline & \multirow[t]{2}{*}{2008} & \multirow[t]{2}{*}{2009} & \multirow[t]{2}{*}{2010} & \multicolumn{2}{|c|}{2011} & \multirow{2}{*}{$\begin{array}{l}2012 \\
\text { Proj. }\end{array}$} \\
\hline & & & & Fourth Rev. & Proj. & \\
\hline National accounts & \multicolumn{6}{|c|}{ (percentage change, unless otherwise indicated) } \\
\hline Real GDP & -3.3 & -17.7 & -0.3 & 3.3 & 4.5 & 2.5 \\
\hline Private consumption & -5.8 & -22.6 & 0.4 & 3.0 & 3.5 & 2.4 \\
\hline Public consumption & 1.5 & -9.5 & -9.7 & -2.0 & 1.0 & 0.0 \\
\hline Gross fixed capital formation & -13.8 & -37.4 & -19.2 & 8.0 & 19.8 & 8.5 \\
\hline Stockbuilding (contribution to growth) & -2.4 & -2.5 & 6.2 & 0.0 & 1.1 & 0.0 \\
\hline Exports of goods and services & 2.0 & -14.1 & 11.5 & 9.5 & 14.3 & 5.5 \\
\hline Imports of goods and services & -10.8 & -33.3 & 11.5 & 9.0 & 18.6 & 6.5 \\
\hline Nominal GDP (billions of lats) & 16.1 & 13.1 & 12.7 & 13.4 & 13.8 & 14.4 \\
\hline Nominal GDP (billions of euros) & 22.7 & 18.6 & 18.1 & 19.1 & 19.7 & 20.5 \\
\hline GDP per capita (thousands of euros) & 10.0 & 8.2 & 8.0 & 8.5 & 8.8 & 9.2 \\
\hline Gross national saving (percent of GDP) & 18.1 & 29.4 & 24.3 & 24.0 & 24.3 & 24.8 \\
\hline Gross capital formation (percent of GDP) & 31.4 & 20.7 & 21.3 & 22.2 & 24.6 & 25.5 \\
\hline Private (percent of GDP) & 26.6 & 16.4 & 17.4 & 16.0 & 18.4 & 20.4 \\
\hline \multicolumn{7}{|l|}{ HICP inflation } \\
\hline Period average & 15.3 & 3.3 & -1.2 & 3.2 & 4.3 & 2.4 \\
\hline End-period & 10.4 & -1.4 & 2.4 & 2.0 & 3.9 & 2.4 \\
\hline \multicolumn{7}{|l|}{ Labor market } \\
\hline Unemployment rate (LFS definition; period average, percent) & 7.8 & 17.3 & 19.0 & 17.2 & 16.4 & 15.3 \\
\hline \multirow[t]{2}{*}{ Real gross wages } & 4.4 & -6.8 & -2.3 & -1.6 & 0.3 & 0.2 \\
\hline & \multicolumn{6}{|c|}{ (percent of GDP, unless otherwise indicated) } \\
\hline \multicolumn{7}{|l|}{ Consolidated general government $1 /$} \\
\hline Total revenue & 35.6 & 36.2 & 36.2 & 38.1 & 36.9 & 37.8 \\
\hline Total expenditure & 39.0 & 43.3 & 42.6 & 42.6 & 40.7 & 39.0 \\
\hline General government gross debt & 17.2 & 32.9 & 39.9 & 43.0 & 39.1 & 40.3 \\
\hline \multicolumn{7}{|l|}{ Money and credit } \\
\hline Credit to private sector (annual percentage change) & 11.0 & -6.9 & -8.4 & -1.7 & -5.6 & 0.1 \\
\hline Broad money (annual percentage change) & -3.9 & -1.9 & 9.8 & 5.4 & 1.1 & 8.3 \\
\hline Residents' FX deposits (percent of total deposits) & 48.6 & 55.6 & 50.3 & 53.8 & 54.0 & 55.1 \\
\hline Treasury Bill rate (365 days, eop, percent) & 11.0 & 10.3 & 1.8 & $\ldots$ & 3.021 & $\ldots$ \\
\hline Money market rate (one month, eop, percent) & 13.3 & 2.7 & 0.6 & $\ldots$ & $1.12 /$ & $\ldots$ \\
\hline \multicolumn{7}{|l|}{ Balance of payments } \\
\hline Gross official reserves (billions of euros) & 3.7 & 4.8 & 5.8 & 5.2 & 5.2 & 5.3 \\
\hline (In months of prospective imports) & 5.4 & 5.9 & 5.7 & 5.0 & 4.8 & 4.6 \\
\hline (percent of broad money and non-resident deposits) & 31.2 & 41.7 & 43.6 & 37.8 & 37.5 & 35.2 \\
\hline Current account balance & -13.2 & 8.7 & 3.0 & 1.7 & -0.3 & -0.7 \\
\hline Trade balance & -17.9 & -7.1 & -7.1 & -7.6 & -9.5 & -10.2 \\
\hline Exports of goods and services & 42.3 & 43.3 & 53.4 & 58.8 & 59.6 & 60.6 \\
\hline Imports of goods and services & 56.2 & 44.4 & 54.3 & 59.3 & 61.7 & 63.3 \\
\hline Gross external debt & 130.9 & 156.8 & 165.6 & 145.4 & 146.5 & 137.9 \\
\hline Net external debt $3 /$ & 57.5 & 58.8 & 53.6 & 34.4 & 42.0 & 34.9 \\
\hline \multicolumn{7}{|l|}{ Exchange rates } \\
\hline Lats per euro (period average) /4 & 0.71 & 0.70 & 0.70 & $\ldots$ & $0.702 /$ & $\ldots$ \\
\hline Lats per U.S. dollar (period average) & 0.48 & 0.51 & 0.53 & $\ldots$ & $0.512 /$ & $\ldots$ \\
\hline REER (period average; CPI based, $2000=100$ ) & 104.5 & 110.3 & 103.6 & $\ldots$ & $\ldots$ & $\ldots$ \\
\hline
\end{tabular}

Sources: Latvian authorities; Eurostat; and IMF staff estimates.

$1 /$ National definition. Includes economy-wide EU grants in revenue and expenditure.

2/ Actual rate as of December 6, 2011.

3/ Gross external debt minus gross external debt assets.

4 / Lat is pegged to the euro at 1 EUR $=0.702804 \mathrm{LVL}$ rate, with \pm 1 percent band. 
Table 2. Latvia. Macroeconomic Framework, 2010-16

\begin{tabular}{|c|c|c|c|c|c|c|c|}
\hline & 2010 & 2011 & 2012 & 2013 & 2014 & 2015 & 2016 \\
\hline & & \multicolumn{6}{|c|}{ Projections } \\
\hline & \multicolumn{7}{|c|}{ (percentage change, unless otherwise indicated) } \\
\hline \multicolumn{8}{|l|}{ National accounts } \\
\hline Real GDP & -0.3 & 4.5 & 2.5 & 4.0 & 4.0 & 4.0 & 4.0 \\
\hline Consumption & -1.6 & 3.0 & 2.0 & 3.0 & 3.7 & 3.9 & 4.0 \\
\hline Private consumption & 0.4 & 3.5 & 2.4 & 3.5 & 4.1 & 4.3 & 4.4 \\
\hline Public consumption & -9.7 & 1.0 & 0.0 & 0.5 & 2.0 & 2.0 & 2.0 \\
\hline Gross fixed capital formation & -19.2 & 19.8 & 8.5 & 9.7 & 8.5 & 8.1 & 8.0 \\
\hline Exports of goods and services & 11.5 & 14.3 & 5.5 & 5.8 & 5.6 & 5.6 & 5.6 \\
\hline Imports of goods and services & 11.5 & 18.6 & 6.5 & 6.4 & 6.7 & 6.8 & 6.8 \\
\hline \multicolumn{8}{|l|}{ Contributions to growth } \\
\hline Domestic demand & 0.1 & 7.6 & 3.6 & 4.8 & 5.2 & 5.3 & 5.4 \\
\hline Net exports & -0.5 & -3.1 & -1.1 & -0.8 & -1.2 & -1.4 & -1.4 \\
\hline \multicolumn{8}{|l|}{ HICP inflation } \\
\hline Period average & -1.2 & 4.3 & 2.4 & 2.3 & 2.1 & 2.2 & 2.3 \\
\hline End-period & 2.4 & 3.9 & 2.4 & 1.6 & 2.2 & 2.3 & 2.1 \\
\hline \multicolumn{8}{|l|}{ Labor market } \\
\hline Unemployment rate (LFS definition; period average, percent) & 19.0 & 16.4 & 15.3 & 14.0 & 12.7 & 11.4 & 10.0 \\
\hline Employment (period average, percent change) & -3.6 & 2.2 & 0.8 & 1.0 & 1.0 & 1.0 & 1.0 \\
\hline Real gross wages & -2.3 & 0.3 & 0.2 & 0.1 & 0.2 & 0.2 & 0.1 \\
\hline & \multicolumn{7}{|c|}{ (percent of GDP) } \\
\hline \multicolumn{8}{|l|}{ Consolidated general government $1 /$} \\
\hline Total revenue & 36.2 & 36.9 & 37.8 & 35.7 & 34.4 & 33.6 & 32.9 \\
\hline Total expenditure & 42.6 & 40.7 & 39.0 & 36.4 & 34.8 & 34.2 & 33.2 \\
\hline Basic fiscal balance & -6.4 & -3.9 & -1.2 & -0.7 & -0.5 & -0.6 & -0.3 \\
\hline Fiscal balance (including restructuring costs) & -7.2 & -3.8 & -1.3 & -0.7 & -0.5 & -0.6 & -0.3 \\
\hline \multicolumn{8}{|l|}{ Saving and investment } \\
\hline Gross national saving & 24.3 & 24.3 & 24.8 & 25.5 & 25.2 & 25.0 & 24.8 \\
\hline Private & 26.2 & 21.4 & 20.4 & 19.9 & 19.2 & 18.6 & 17.7 \\
\hline Public 2/ & -1.9 & 2.9 & 4.4 & 5.6 & 6.0 & 6.4 & 7.1 \\
\hline Foreign saving $3 /$ & -3.0 & 0.3 & 0.7 & 1.0 & 2.0 & 2.8 & 3.6 \\
\hline Gross capital formation & 21.3 & 24.6 & 25.5 & 26.5 & 27.2 & 27.8 & 28.4 \\
\hline Private & 17.4 & 18.4 & 20.4 & 21.4 & 22.1 & 22.3 & 22.4 \\
\hline Public & 3.9 & 6.2 & 5.1 & 5.1 & 5.0 & 5.5 & 6.0 \\
\hline \multicolumn{8}{|l|}{ External sector } \\
\hline Current account balance & 3.0 & -0.3 & -0.7 & -1.0 & -2.0 & -2.8 & -3.6 \\
\hline Net IIP & -81.5 & -72.2 & -66.6 & -61.2 & -57.6 & -55.2 & -54.0 \\
\hline Gross external debt & 165.6 & 146.5 & 137.9 & 132.9 & 124.6 & 116.9 & 113.5 \\
\hline Net external debt 4/ & 53.6 & 42.0 & 34.9 & 28.2 & 23.3 & 19.9 & 17.6 \\
\hline \multicolumn{8}{|l|}{ Memorandum items: } \\
\hline Gross official reserves (billions of euros) & 5.8 & 5.2 & 5.3 & 6.5 & 6.5 & 6.3 & 6.8 \\
\hline Nominal GDP (billions of lats) & 12.7 & 13.8 & 14.4 & 15.3 & 16.2 & 17.2 & 18.3 \\
\hline Nominal GDP (billions of euros) & 18.1 & 19.7 & 20.5 & 21.8 & 23.1 & 24.5 & 26.0 \\
\hline
\end{tabular}

Sources: Latvian authorities; and IMF staff estimates.

1/ National definition. Includes economy-wide EU grants in revenue and expenditure.

2/ Includes 2nd pillar contributions and privatization receipts, excludes bank restructuring costs.

3/ Current account deficit (+ indicates a surplus)

4/ Gross external debt minus gross external debt assets. 
Table 3. Latvia: General Government Operations, 2010-13

\begin{tabular}{|c|c|c|c|c|c|c|}
\hline & \multirow{2}{*}{$\begin{array}{r}2010 \\
\text { Actual }\end{array}$} & \multicolumn{2}{|c|}{2011} & \multicolumn{2}{|c|}{2012} & \multirow{2}{*}{$\begin{array}{l}2013 \\
\text { Proj. }\end{array}$} \\
\hline & & $\begin{array}{l}\text { Fourth } \\
\text { Review }\end{array}$ & Proj. & $\begin{array}{l}\text { Fourth } \\
\text { Review }\end{array}$ & Proj. & \\
\hline & \multicolumn{6}{|c|}{ (millions of lats) } \\
\hline Total revenue and grants & 4,607 & 5,119 & 5,104 & 5,136 & 5,453 & 5,468 \\
\hline Tax revenue & 3,403 & 3,714 & 3,841 & 3,852 & 4,054 & 4,124 \\
\hline Direct Taxes & 2,074 & 2,153 & 2,284 & 2,228 & 2,392 & 2,390 \\
\hline Corporate Income Tax & 112 & 121 & 187 & 127 & 211 & 229 \\
\hline Personal Income Tax & 779 & 739 & 779 & 764 & 812 & 842 \\
\hline Social Security Contributions & 1,093 & 1,193 & 1,210 & 1,232 & 1,252 & 1,186 \\
\hline Real Estate and Property Taxes & 90 & 99 & 107 & 105 & 116 & 134 \\
\hline Indirect Taxes & 1,329 & 1,561 & 1,558 & 1,624 & 1,662 & 1,734 \\
\hline VAT & 825 & 972 & 964 & 991 & 1,029 & 1,080 \\
\hline Excises & 458 & 476 & 479 & 515 & 509 & 527 \\
\hline Other indirect taxes & 46 & 113 & 114 & 118 & 125 & 127 \\
\hline Non Tax, self-earned and other revenue & 604 & 507 & 519 & 490 & 553 & 582 \\
\hline EU and miscellaneous funds & 600 & 898 & 744 & 794 & 846 & 762 \\
\hline Total expenditure $1 /$ & 5,424 & 5,715 & 5,640 & 5,466 & 5,626 & 5,579 \\
\hline Current expenditure & 5,034 & 5,050 & 5,016 & 5,095 & 5,114 & 5,067 \\
\hline Primary Current Expenditure & 4,855 & 4,824 & 4,804 & 4,810 & 4,856 & 4,785 \\
\hline Remuneration & 1,087 & 1,068 & 1,065 & 1,083 & 1,072 & 1,104 \\
\hline Goods and Services & 691 & 583 & 633 & 600 & 625 & 650 \\
\hline Subsidies and Transfers & 2,937 & 2,992 & 2,951 & 2,938 & 2,971 & 2,832 \\
\hline Subsidies to companies and institutions & 1,178 & 1,375 & 1,312 & 1,316 & 1,341 & 1,206 \\
\hline E.U. funds related subsidies & 784 & 790 & 723 & 725 & 743 & 607 \\
\hline Social Support & 1,745 & 1,604 & 1,626 & 1,608 & 1,616 & 1,611 \\
\hline International cooperation & 15 & 13 & 13 & 13 & 14 & 15 \\
\hline Payments to EU budget & 121 & 130 & 126.1 & 137 & 139 & 147 \\
\hline Net lending and other current expenditure & 18 & 51 & 28 & 51 & 50 & 52 \\
\hline Interest & 180 & 227 & 212 & 285 & 258 & 282 \\
\hline Capital expenditure & 390 & 624 & 625 & 551 & 512 & 512 \\
\hline E.U. funds related capital expenditure & 141 & 359 & 425 & 293 & 321 & 288 \\
\hline National capital expenditure & & & 200 & 258 & 192 & 224 \\
\hline Measures to be identified & 0 & 0 & 0 & -180 & 0 & 0 \\
\hline Possible contingencies $2 /$ & 0 & 40 & 0 & 0 & 0 & 0 \\
\hline Basic fiscal balance & -817 & -596 & -537 & -330 & -173 & -111 \\
\hline Restructuring costs & 102 & 150 & -11 & 0 & 14 & 0 \\
\hline incl. bank restructuring costs & 102 & 150 & -68 & 0 & 14 & 0 \\
\hline Fiscal balance & -919 & -746 & -526 & -330 & -187 & -111 \\
\hline Financing (net) & 919 & 746 & 526 & 330 & 187 & 80 \\
\hline Domestic financing & 146 & 156 & 227 & 40 & -111 & 260 \\
\hline External financing & 756 & 590 & 299 & 290 & 299 & -179 \\
\hline Errors and omissions & 16 & 0 & 0 & 0 & 0 & 0 \\
\hline ESA correction & -258 & & -45 & & -180 & -196 \\
\hline ESA balance & -1060 & & -553 & & -303 & -257 \\
\hline ESA sustainable balance $3 /$ & -1060 & & -553 & & -377 & -329 \\
\hline
\end{tabular}


Table 3. Latvia: General Government Operations, 2010-13 (concluded)

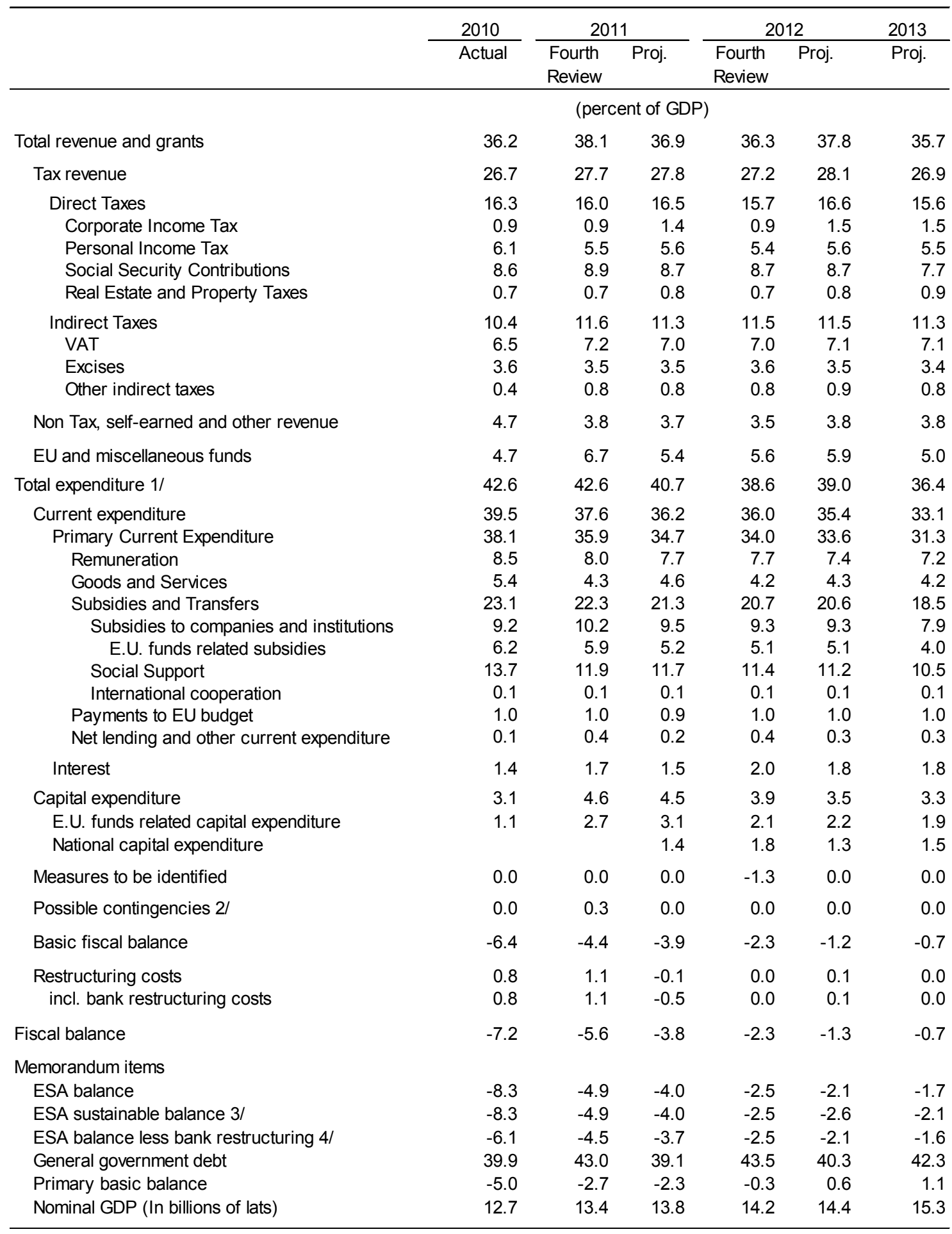

Sources: Latvian authorities; and IMF staff estimates.

1/ Total expenditure excludes net acquisition of financial assets and other bank restructuring costs.

2/ Includes budgetary contingency reserves and estimated structural spending needs.

3/ Excludes one-off and unsustainable measures and a (negative) ESA correction buffer for unforeseen events.

4/ The bank restructuring costs are calculated in accordance with ESA 95 definitions. 
Table 4. Latvia: Fiscal Balances and Debt, 2006-12

\begin{tabular}{|c|c|c|c|c|c|c|c|}
\hline & 2006 & 2007 & 2008 & 2009 & 2010 & 2011 & 2012 \\
\hline \multirow{2}{*}{\multicolumn{8}{|c|}{ Fiscal balances }} \\
\hline & & & & & & & \\
\hline Basic fiscal balance (excl. bank restructuring) & -0.5 & 0.6 & -3.4 & -7.1 & -6.4 & -3.9 & -1.2 \\
\hline \multicolumn{8}{|l|}{ Alternative fiscal balances } \\
\hline \multicolumn{8}{|l|}{ (i) Authorities' definition } \\
\hline plus net lending & & 0.0 & 0.0 & 0.3 & 0.1 & 0.2 & 0.3 \\
\hline Basic fiscal balance, authorities' definition & $\ldots$ & 0.6 & -3.4 & -6.8 & -6.3 & -3.7 & -0.9 \\
\hline \multicolumn{8}{|l|}{ (ii) Adjustment for 2nd pillar contribution diversion } \\
\hline less gain from 2 nd pillar contributions $<8$ percent & 0.0 & 0.0 & 0.0 & 1.2 & 1.6 & 1.7 & 1.7 \\
\hline Fiscal balance, adjusted for pension diversion $1 /$ & -0.5 & 0.6 & -3.4 & -8.3 & -8.1 & -5.6 & -2.9 \\
\hline \multicolumn{8}{|l|}{ (iii) Adjustment for EU-related operations } \\
\hline less revenues from EU & 2.3 & 3.1 & 2.7 & 4.1 & 4.7 & 5.4 & 5.9 \\
\hline plus EU-related spending & 4.1 & 3.6 & 4.3 & 6.1 & 7.3 & 8.3 & 7.4 \\
\hline Non-EU basic balance & 1.3 & 1.1 & -1.8 & -5.0 & -3.9 & -1.0 & 0.3 \\
\hline \multicolumn{8}{|l|}{ (iv) Primary balance } \\
\hline plus interest & 0.6 & 0.4 & 0.4 & 1.2 & 1.4 & 1.5 & 1.8 \\
\hline Primary basic balance & 0.1 & 1.0 & -3.0 & -5.9 & -5.0 & -2.3 & 0.6 \\
\hline \multicolumn{8}{|l|}{ (v) Recognition of bank restructuring costs } \\
\hline less bank restructuring costs & 0.0 & 0.0 & 4.2 & 0.8 & 0.8 & -0.5 & 0.1 \\
\hline Overall balance $2 /$ & -0.5 & 0.6 & -7.5 & -7.8 & -7.2 & -3.4 & -1.3 \\
\hline \multicolumn{8}{|l|}{ (vi) Program-relevant ESA balance } \\
\hline ESA definition less bank restructuring & -0.5 & -0.3 & -4.2 & -8.6 & -6.1 & -3.7 & -2.1 \\
\hline \multicolumn{8}{|l|}{ (vii) ESA deficit (relevant for euro adoption) } \\
\hline plus ESA bank restructuring & 0.0 & 0.0 & 0.0 & 1.1 & 2.3 & 0.3 & 0.0 \\
\hline ESA deficit & -0.5 & -0.3 & -4.2 & -9.7 & -8.3 & -4.0 & -2.1 \\
\hline \multicolumn{8}{|l|}{ Public debt } \\
\hline Gross debt & 9.9 & 7.8 & 17.2 & 32.9 & 39.9 & 39.1 & 40.3 \\
\hline of which foreign currency-denominated & 5.2 & 4.4 & 9.9 & 25.6 & 32.6 & 31.6 & 32.4 \\
\hline Net debt (debt less government deposits) & 7.5 & 4.7 & 13.2 & 23.0 & 31.4 & 32.7 & 32.6 \\
\hline Net debt if no more bank restructuring & 7.5 & 4.7 & 13.2 & 23.0 & 31.4 & 33.2 & 33.0 \\
\hline
\end{tabular}

Sources: Latvian authorities; and IMF staff estimates.

1/ Definition used at First Review.

2/ 2011 excludes non-bank restructuring costs. 
Table 5. Latvia: Public Sector Debt Sustainability Framework, 2006-16

(In percent of GDP, unless otherwise indicated)

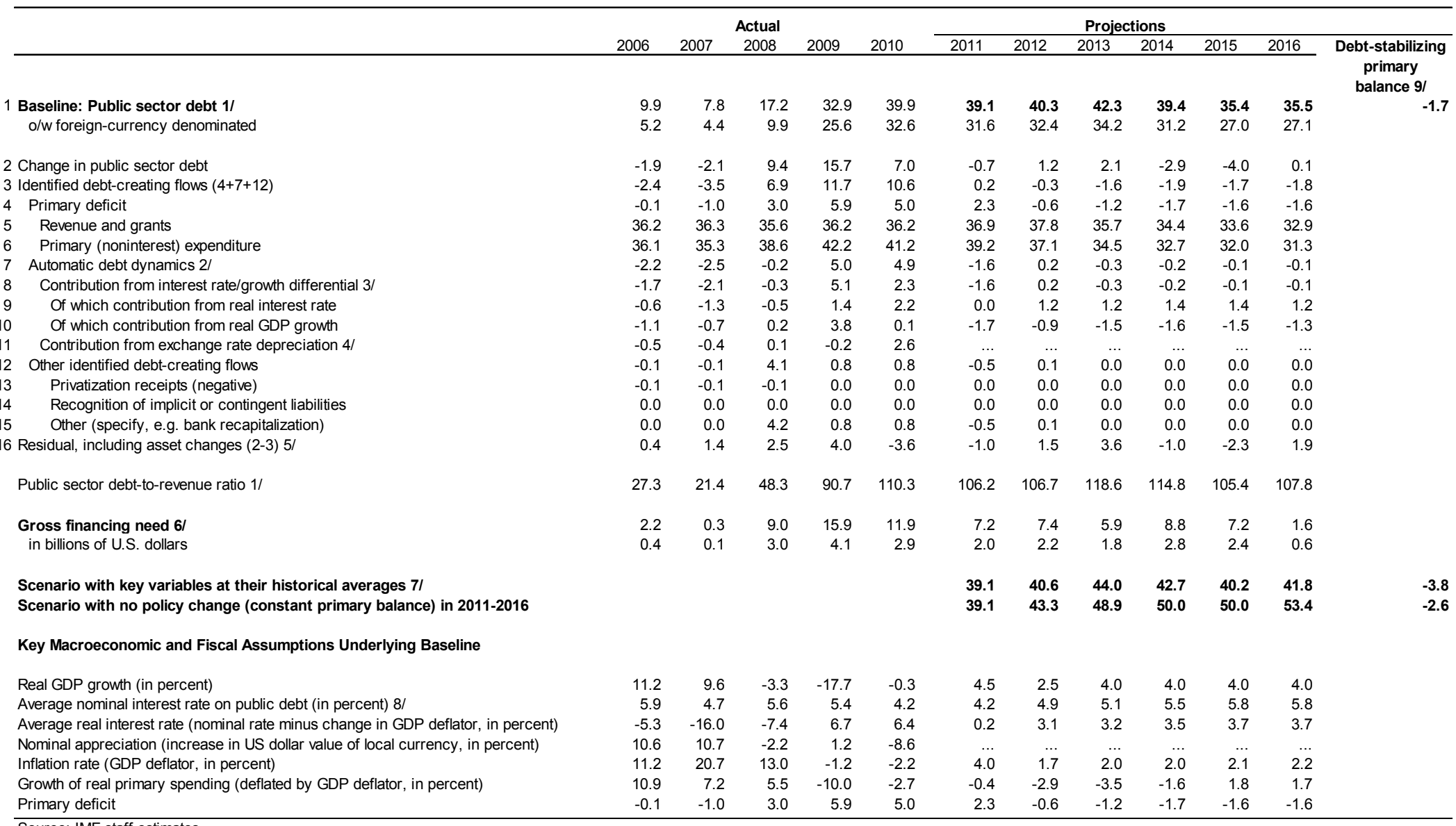

Primary deficit

Source: IMF staff estimates.

$2 /$ Derived as $[(r-\pi(1+g)-g+\alpha \varepsilon(1+r)](1+g+\pi+g \pi))$ times previous period debt ratio, with $r=$ interest rate; $\pi=$ growth rate of GDP deflator; $g=$ real GDP growth rate; $\alpha=$ share of foreign-currency

denominated debt; and $\varepsilon=$ nominal exchange rate depreciation (measured by increase in local currency value of $U . S$. dollar).

$3 /$ The real interest rate contribution is derived from the denominator in footnote $2 /$ as $r-\pi(1+g)$ and the real growth contribution as $-g$.

$4 /$ The exchange rate contribution is derived from the numerator in footnote $2 /$ as $\alpha \varepsilon(1+r)$.

$5 /$ For projections, this line includes exchange rate changes.

7/ The key puriable sector debt, plus short-term debt at end of previous period.

Terived as nominal interest expenditure divided by previous; and primary balance in percent of GDP.

9/ Assumes that key variables (real GDP growth, real interest rate, and other identified debt-creating flows) remain at the level of the last projection year.

CInternational Monetary Fund. Not for Redistribution 
Figure 8. Latvia: Public Debt Sustainability: Bound Tests 1/ (Public debt in percent of GDP)

Baseline and historical scenarios

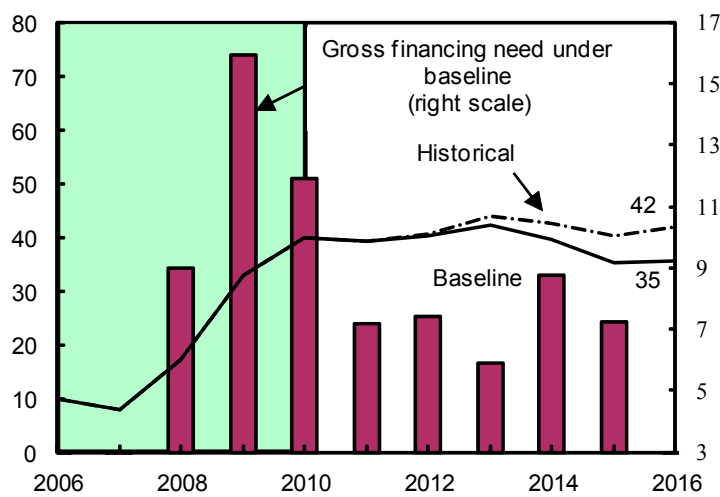

Growth shock (in percent per year)

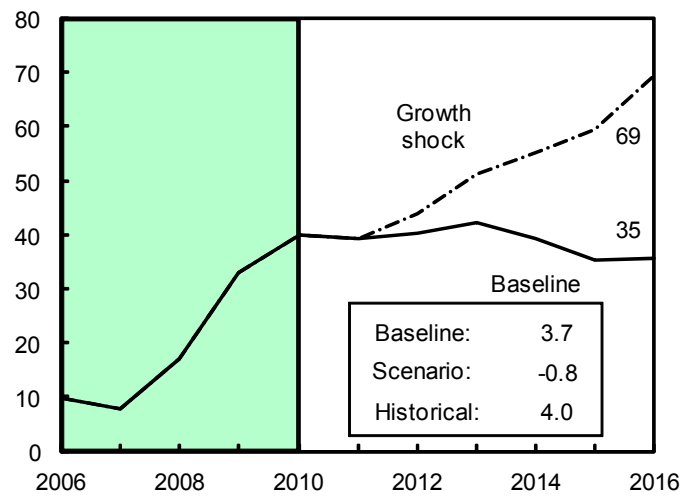

Combined shock 2/

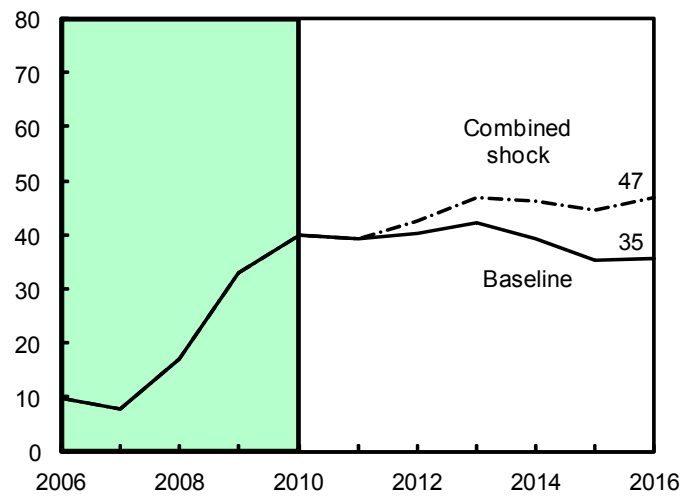

Interest rate shock (in percent)

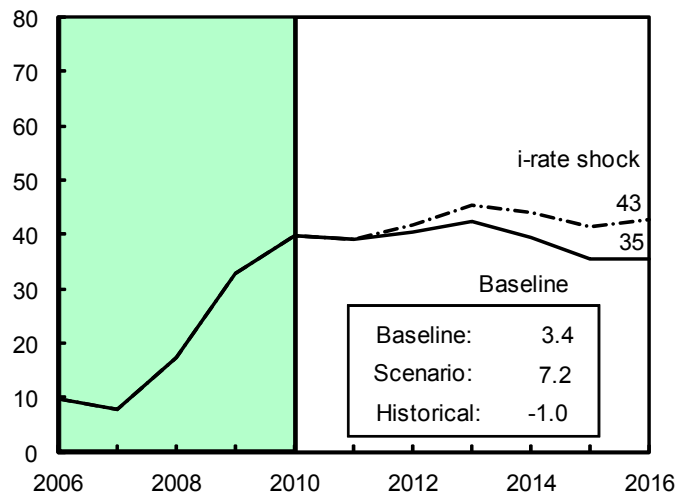

Primary balance shock (in percent of GDP) and no policy change scenario (constant primary balance)

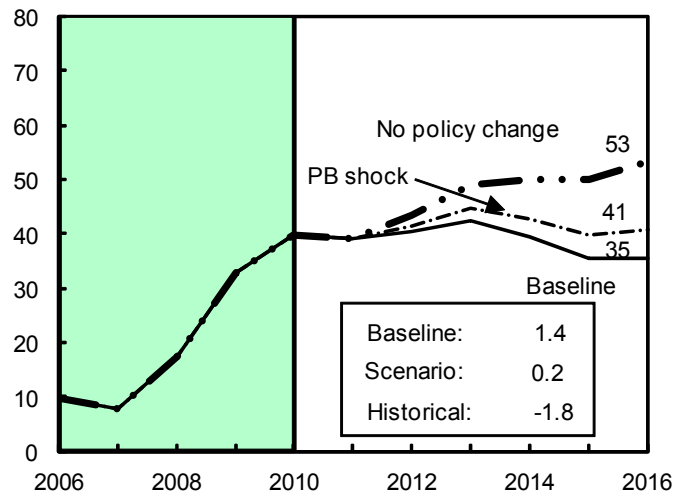

Real depreciation and contingent liabilities shocks $3 /$

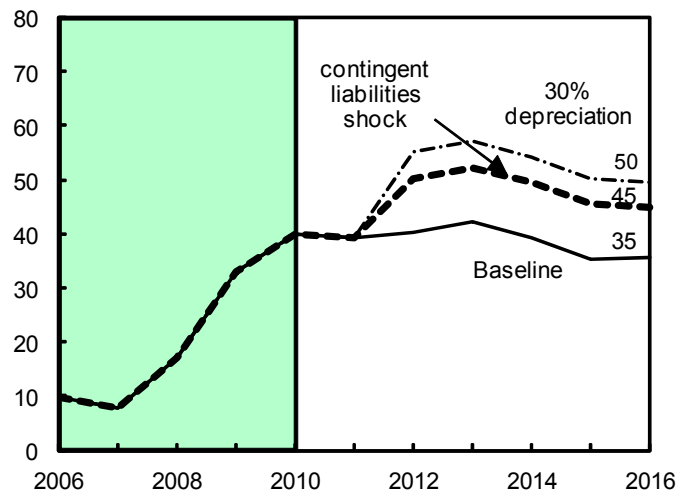

Source: IMF staff estimates.

1/ Shaded areas represent actual data. Individual shocks are permanent one-half standard deviation shocks. Figures in the boxes represent average projections for the respective variables in the baseline and scenario being presented. Ten-year historical average for the variable is also shown.

2/ Permanent $1 / 4$ standard deviation shocks applied to real interest rate, growth rate, and primary balance.

3/ One-time real depreciation of 30 percent and 10 percent of GDP shock to contingent liabilities occur in 2010, with real depreciation defined as nominal depreciation (measured by percentage fall in dollar value of local currency) minus domestic inflation (based on GDP deflator). 
Table 6. Latvia: Medium-Term Balance of Payments, 2010-16

\begin{tabular}{|c|c|c|c|c|c|c|c|}
\hline & 2010 & 2011 & 2012 & 2013 & 2014 & 2015 & 2016 \\
\hline & & \multicolumn{6}{|c|}{ Projections } \\
\hline & \multicolumn{7}{|c|}{ (millions of euros) } \\
\hline Current account & 540 & -69 & -148 & -213 & -457 & -691 & -934 \\
\hline Trade balance (fob) & $-1,280$ & $-1,878$ & $-2,089$ & $-2,250$ & $-2,473$ & $-2,734$ & $-3,030$ \\
\hline Exports & 6,873 & 8,029 & 8,516 & 9,012 & 9,473 & 9,996 & 10,583 \\
\hline Imports & 8,153 & 9,907 & 10,605 & 11,262 & 11,945 & 12,730 & 13,614 \\
\hline Services & 1,107 & 1,465 & 1,532 & 1,612 & 1,670 & 1,734 & 1,806 \\
\hline Credit & 2,787 & 3,707 & 3,931 & 4,160 & 4,373 & 4,614 & 4,886 \\
\hline Debit & 1,680 & 2,242 & 2,399 & 2,548 & 2,703 & 2,880 & 3,080 \\
\hline Income & 59 & -274 & -274 & -248 & -315 & -335 & -343 \\
\hline Compensation of employees & 430 & 451 & 472 & 496 & 522 & 549 & 578 \\
\hline Investment income & -371 & -725 & -746 & -745 & -837 & -884 & -921 \\
\hline Current transfers & 654 & 618 & 683 & 673 & 660 & 644 & 634 \\
\hline of which: EU (net) & 373 & 331 & 383 & 344 & 297 & 243 & 190 \\
\hline Capital and financial account & $-1,011$ & -632 & 550 & 1,943 & 1,746 & 1,796 & 1,504 \\
\hline Capital account & 352 & 537 & 613 & 531 & 458 & 402 & 353 \\
\hline Financial account & $-1,363$ & $-1,170$ & -63 & 1,411 & 1,288 & 1,394 & 1,151 \\
\hline Direct investment & 270 & 807 & 718 & 699 & 749 & 803 & 862 \\
\hline of which: equity capital & 480 & 542 & 563 & 598 & 641 & 688 & 739 \\
\hline Portfolio investment & -165 & 136 & 589 & 1,214 & 885 & 649 & 396 \\
\hline of which: general government & -2 & 369 & 750 & 1,300 & 975 & 750 & 500 \\
\hline Financial derivatives & -168 & 0 & 0 & 0 & 0 & 0 & 0 \\
\hline Other investment & $-1,300$ & $-2,113$ & $-1,371$ & -502 & -347 & -58 & -107 \\
\hline Trade credit & 236 & -33 & 24 & 15 & 26 & 31 & 35 \\
\hline Assets & -170 & -224 & -89 & -91 & -84 & -96 & -107 \\
\hline Liabilities & 406 & 191 & 112 & 106 & 110 & 127 & 143 \\
\hline Loans & $-2,560$ & $-2,381$ & $-1,314$ & -548 & -391 & -84 & -111 \\
\hline Assets & 455 & 79 & 338 & 253 & 177 & 133 & 100 \\
\hline Liabilities & $-3,015$ & $-2,460$ & $-1,652$ & -801 & -568 & -217 & -210 \\
\hline Currency and deposits & 1,080 & 322 & -80 & 30 & 18 & -6 & -31 \\
\hline Assets & -913 & -249 & -571 & -436 & -462 & -490 & -521 \\
\hline Liabilities & 1,994 & 571 & 491 & 466 & 480 & 485 & 490 \\
\hline Other & -56 & -22 & 0 & 0 & 0 & 0 & 0 \\
\hline Errors and omissions & 96 & 0 & 0 & 0 & 0 & 0 & 0 \\
\hline Overall balance & -375 & -701 & 402 & 1,730 & 1,288 & 1,105 & 570 \\
\hline Financing & 375 & 701 & -402 & $-1,730$ & $-1,288$ & $-1,105$ & -570 \\
\hline Change in reserve assets (+ denotes decline) & -725 & 607 & -71 & $-1,234$ & -57 & 220 & -490 \\
\hline IMF (net) & 300 & 0 & -327 & -494 & -230 & -64 & 0 \\
\hline Purchases & 300 & 0 & 0 & 0 & 0 & 0 & 0 \\
\hline Repurchases & 0 & 0 & -327 & -494 & -230 & -64 & 0 \\
\hline Other official financing (net) & 800 & 94 & -3 & -2 & $-1,002$ & $-1,260$ & -80 \\
\hline Disbursements & 800 & 100 & 0 & 0 & 0 & 0 & 0 \\
\hline Repayments & 0 & -6 & -3 & -2 & $-1,002$ & $-1,260$ & -80 \\
\hline
\end{tabular}


Table 6. Latvia: Medium-Term Balance of Payments, 2010-16 (concluded)

\begin{tabular}{|c|c|c|c|c|c|c|c|}
\hline & 2010 & 2011 & 2012 & 2013 & 2014 & 2015 & 2016 \\
\hline & & \multicolumn{6}{|c|}{ Projections } \\
\hline Memorandum items: & \multicolumn{7}{|c|}{ (percent of GDP, unless otherwise indicated) } \\
\hline Current account & 3.0 & -0.3 & -0.7 & -1.0 & -2.0 & -2.8 & -3.6 \\
\hline Trade balance (fob) & -7.1 & -9.5 & -10.2 & -10.3 & -10.7 & -11.2 & -11.6 \\
\hline Exports & 38.0 & 40.8 & 41.5 & 41.4 & 41.0 & 40.8 & 40.6 \\
\hline Imports & 45.0 & 50.3 & 51.6 & 51.7 & 51.7 & 51.9 & 52.3 \\
\hline Services & 6.1 & 7.4 & 7.5 & 7.4 & 7.2 & 7.1 & 6.9 \\
\hline Credit & 15.4 & 18.8 & 19.1 & 19.1 & 18.9 & 18.8 & 18.8 \\
\hline Debit & 9.3 & 11.4 & 11.7 & 11.7 & 11.7 & 11.7 & 11.8 \\
\hline Income & 0.3 & -1.4 & -1.3 & -1.1 & -1.4 & -1.4 & -1.3 \\
\hline Compensation of employees & 2.4 & 2.3 & 2.3 & 2.3 & 2.3 & 2.2 & 2.2 \\
\hline Investment income & -2.0 & -3.7 & -3.6 & -3.4 & -3.6 & -3.6 & -3.5 \\
\hline Current transfers & 3.6 & 3.1 & 3.3 & 3.1 & 2.9 & 2.6 & 2.4 \\
\hline of which: EU (net) & 2.1 & 1.7 & 1.9 & 1.6 & 1.3 & 1.0 & 0.7 \\
\hline Net FDI & 1.5 & 4.1 & 3.5 & 3.2 & 3.2 & 3.3 & 3.3 \\
\hline Export G\&S growth (value, fob, percent change) & 20.3 & 21.5 & 6.1 & 5.8 & 5.1 & 5.5 & 5.9 \\
\hline Import G\&S growth (value, fob, percent change) & 12.1 & 23.6 & 7.0 & 6.2 & 6.1 & 6.6 & 6.9 \\
\hline Export G\&S price increase (percent change) & 7.1 & 7.2 & 0.5 & 0.0 & -0.4 & -0.1 & 0.3 \\
\hline Import G\&S price increase (percent change) & 6.3 & 6.4 & 0.5 & -0.1 & -0.6 & -0.2 & 0.2 \\
\hline Gross reserves (billions of euros) & 5.8 & 5.2 & 5.3 & 6.5 & 6.5 & 6.3 & 6.8 \\
\hline (in months of prospective imports) & 5.7 & 4.8 & 4.6 & 5.3 & 5.0 & 4.5 & 4.6 \\
\hline Reserve cover $1 /$ & 57.2 & 43.2 & 45.1 & 58.1 & 51.7 & 49.7 & 56.5 \\
\hline Banks' short-term liabilities (billions of euros) & 7.7 & 8.0 & 8.4 & 8.4 & 8.6 & 8.8 & 9.1 \\
\hline Total short-term debt (billions of euros) & 9.6 & 10.1 & 10.5 & 10.6 & 10.9 & 11.2 & 11.5 \\
\hline Reserves (percent of short-term external debt) & 60.3 & 51.5 & 50.0 & 61.0 & 60.1 & 56.7 & 59.0 \\
\hline Gross external debt (billions of euros) & 30.0 & 28.9 & 28.3 & 29.0 & 28.8 & 28.7 & 29.6 \\
\hline Medium- and long-term (billions of euros) & 20.4 & 18.8 & 17.8 & 18.3 & 17.9 & 17.5 & 18.0 \\
\hline Short-term (billions of euros) & 9.6 & 10.1 & 10.5 & 10.6 & 10.9 & 11.2 & 11.5 \\
\hline Net external debt (billions of euros) $2 /$ & 9.7 & 8.3 & 7.2 & 6.1 & 5.4 & 4.9 & 4.6 \\
\hline Gross external debt & 165.6 & 146.5 & 137.9 & 132.9 & 124.6 & 116.9 & 113.5 \\
\hline Medium- and long-term & 112.6 & 95.4 & 86.8 & 84.1 & 77.5 & 71.4 & 69.2 \\
\hline Short-term & 53.0 & 51.1 & 51.1 & 48.9 & 47.1 & 45.5 & 44.3 \\
\hline Net external debt & 53.6 & 42.0 & 34.9 & 28.2 & 23.3 & 19.9 & 17.6 \\
\hline Nominal GDP (billions of euros) & 18.1 & 19.7 & 20.5 & 21.8 & 23.1 & 24.5 & 26.0 \\
\hline U.S. dollar per euro (period average) & 1.33 & & & & & & \\
\hline Lats per euro (period average) & 0.70 & 0.70 & 0.70 & 0.70 & 0.70 & 0.70 & 0.70 \\
\hline
\end{tabular}

Sources: Latvian authorities; and IMF staff estimates.

$1 /$ Gross reserves in percent of banks' short-term liabilities and amortization minus the current account surplus.

2/ Gross external debt minus gross external debt assets. 
Table 7. Latvia: External Debt Dynamics, 2008-16

\begin{tabular}{|c|c|c|c|c|c|c|c|c|c|}
\hline & 2008 & 2009 & 2010 & 2011 & 2012 & 2013 & 2014 & 2015 & 2016 \\
\hline & \multicolumn{9}{|c|}{ (billions of euros) } \\
\hline Gross external debt & 29.8 & 29.1 & 30.0 & 28.9 & 28.3 & 29.0 & 28.8 & 28.7 & 29.6 \\
\hline Public 1/ & 2.5 & 4.8 & 6.0 & 6.5 & 6.9 & 7.7 & 7.4 & 6.8 & 7.1 \\
\hline Short-term & 0.5 & 0.1 & 0.1 & 0.1 & 0.1 & 0.1 & 0.1 & 0.1 & 0.1 \\
\hline Long-term & 2.0 & 4.6 & 5.9 & 6.4 & 6.8 & 7.5 & 7.2 & 6.6 & 7.0 \\
\hline Private & 27.3 & 24.3 & 24.0 & 22.4 & 21.4 & 21.3 & 21.4 & 21.9 & 22.4 \\
\hline Banks & 18.5 & 15.5 & 15.6 & 14.0 & 12.9 & 12.7 & 12.7 & 13.1 & 13.5 \\
\hline Short-term & 7.6 & 5.5 & 7.7 & 8.0 & 8.4 & 8.4 & 8.6 & 8.8 & 9.1 \\
\hline Long-term & 10.9 & 10.0 & 7.9 & 6.0 & 4.6 & 4.3 & 4.1 & 4.3 & 4.4 \\
\hline Corporate & 6.0 & 5.8 & 5.8 & 5.7 & 5.7 & 5.7 & 5.8 & 5.9 & 6.0 \\
\hline Short-term & 1.8 & 1.5 & 1.8 & 1.9 & 2.0 & 2.1 & 2.1 & 2.2 & 2.3 \\
\hline Long-term & 4.2 & 4.3 & 4.0 & 3.8 & 3.7 & 3.7 & 3.7 & 3.7 & 3.6 \\
\hline \multirow[t]{2}{*}{ Other } & 2.7 & 3.1 & 2.6 & 2.7 & 2.8 & 2.8 & 2.9 & 3.0 & 3.0 \\
\hline & \multicolumn{9}{|c|}{ (percent of GDP) } \\
\hline Gross external debt & 130.9 & 156.8 & 165.6 & 146.5 & 137.9 & 132.9 & 124.6 & 116.9 & 113.5 \\
\hline Public & 11.0 & 25.8 & 33.2 & 32.9 & 33.5 & 35.2 & 31.9 & 27.5 & 27.4 \\
\hline Short-term & 2.4 & 0.8 & 0.7 & 0.6 & 0.6 & 0.6 & 0.5 & 0.5 & 0.5 \\
\hline Long-term & 8.6 & 25.0 & 32.5 & 32.3 & 32.9 & 34.6 & 31.4 & 27.0 & 26.9 \\
\hline Private & 119.9 & 130.9 & 132.4 & 113.6 & 104.4 & 97.8 & 92.7 & 89.4 & 86.1 \\
\hline Banks & 81.6 & 83.4 & 86.0 & 71.1 & 62.9 & 58.4 & 55.1 & 53.3 & 51.7 \\
\hline Short-term & 33.5 & 29.7 & 42.4 & 40.7 & 40.7 & 38.7 & 37.3 & 35.9 & 34.9 \\
\hline Long-term & 48.1 & 53.8 & 43.6 & 30.4 & 22.3 & 19.6 & 17.7 & 17.4 & 16.8 \\
\hline Corporate & 26.3 & 31.1 & 32.1 & 28.9 & 27.9 & 26.4 & 25.1 & 24.0 & 22.8 \\
\hline Short-term & 7.9 & 8.2 & 10.0 & 9.7 & 9.9 & 9.6 & 9.3 & 9.1 & 9.0 \\
\hline Long-term & 18.4 & 22.9 & 22.1 & 19.2 & 18.1 & 16.8 & 15.8 & 14.9 & 13.9 \\
\hline \multirow[t]{2}{*}{ Other } & 12.0 & 16.4 & 14.4 & 13.6 & 13.5 & 13.0 & 12.6 & 12.1 & 11.6 \\
\hline & \multicolumn{9}{|c|}{ (debt dynamics, change in debt to GDP ratio) } \\
\hline Total Debt to GDP & 2.6 & 25.8 & 8.9 & -19.2 & -8.6 & -4.9 & -8.3 & -7.7 & -3.4 \\
\hline Due to change in debt & 12.9 & -3.6 & 4.9 & -5.7 & -2.6 & 2.9 & -0.8 & -0.5 & 3.5 \\
\hline Due to nominal GDP & -10.3 & 29.4 & 4.0 & -13.4 & -6.0 & -7.9 & -7.6 & -7.2 & -6.9 \\
\hline Public Debt to GDP & 5.8 & 14.8 & 7.4 & -0.3 & 0.6 & 1.7 & -3.3 & -4.4 & -0.2 \\
\hline Due to change in debt & 6.3 & 12.3 & 6.7 & 2.3 & 2.0 & 3.6 & -1.3 & -2.5 & 1.5 \\
\hline Due to nominal GDP & -0.4 & 2.5 & 0.7 & -2.7 & -1.4 & -1.9 & -2.0 & -1.8 & -1.6 \\
\hline Private Debt to GDP & -3.3 & 11.0 & 1.5 & -18.8 & -9.2 & -6.6 & -5.0 & -3.3 & -3.3 \\
\hline Due to change in debt & 6.6 & -15.9 & -1.9 & -8.1 & -4.5 & -0.7 & 0.5 & 2.0 & 2.0 \\
\hline Due to nominal GDP & -9.9 & 26.9 & 3.4 & -10.7 & -4.7 & -6.0 & -5.6 & -5.4 & -5.3 \\
\hline \multicolumn{10}{|l|}{ Memorandum items: } \\
\hline Nominal GDP (billions of euros) & 22.7 & 18.6 & 18.1 & 19.7 & 20.5 & 21.8 & 23.1 & 24.5 & 26.0 \\
\hline
\end{tabular}

Sources: Latvian authorities and IMF staff estimates.

1/ Debt of general government, including Bank of Latvia. 
Table 8. Latvia: External Debt Sustainability Framework, 2006-16

(In percent of GDP, unless otherwise indicated)

\begin{tabular}{|c|c|c|c|c|c|c|c|c|c|c|c|c|c|c|}
\hline & \multicolumn{5}{|c|}{ Actual } & & & \multicolumn{7}{|c|}{ Projections } \\
\hline & 2006 & 2007 & 2008 & 2009 & 2010 & & & 2011 & 2012 & 2013 & 2014 & 2015 & 2016 & Debt-stabilizing \\
\hline 1 Baseline: External debt & 114.6 & 128.4 & 130.9 & 156.8 & 165.6 & & & 146.5 & 137.9 & 132.9 & 124.6 & 116.9 & 113.5 & -6.4 \\
\hline 2 Change in external debt & 14.5 & 13.7 & 2.6 & 25.8 & 8.9 & & & -19.2 & -8.6 & -4.9 & -8.3 & -7.7 & -3.4 & \\
\hline 3 Identified external debt-creating flows $(4+8+9)$ & -3.0 & -12.2 & 1.5 & 23.3 & -0.2 & & & -9.9 & -6.2 & -7.6 & -6.4 & -5.2 & -4.3 & \\
\hline 4 Current account deficit, excluding interest payments & 19.4 & 18.4 & 7.8 & -13.2 & -6.9 & & & -3.9 & -3.4 & -2.9 & -2.0 & -1.1 & -0.3 & \\
\hline Deficit in balance of goods and services & 22.4 & 20.6 & 13.9 & 1.1 & 1.0 & & & 2.1 & 2.7 & 2.9 & 3.5 & 4.1 & 4.7 & \\
\hline Exports & 44.2 & 41.6 & 42.3 & 43.3 & 53.4 & & & 59.6 & 60.6 & 60.5 & 59.9 & 59.6 & 59.4 & \\
\hline Imports & 66.5 & 62.2 & 56.2 & 44.4 & 54.3 & & & 61.7 & 63.3 & 63.4 & 63.4 & 63.7 & 64.1 & \\
\hline 8 Net non-debt creating capital inflows (negative) & -6.5 & -6.8 & -1.4 & 2.5 & -1.2 & & & -3.3 & -3.4 & -3.4 & -3.4 & -3.4 & -3.5 & \\
\hline 9 Automatic debt dynamics $1 /$ & -16.0 & -23.8 & -4.9 & 34.0 & 7.9 & & & -2.6 & 0.6 & -1.3 & -1.0 & -0.7 & -0.5 & \\
\hline Contribution from nominal interest rate & 3.2 & 4.1 & 5.4 & 4.6 & 3.9 & & & 4.3 & 4.1 & 3.8 & 4.0 & 3.9 & 3.9 & \\
\hline Contribution from real GDP growth & -9.0 & -8.3 & 3.9 & 28.4 & 0.5 & & & -6.9 & -3.5 & -5.2 & -5.0 & -4.6 & -4.4 & \\
\hline Contribution from price and exchange rate changes $2 /$ & -10.1 & -19.6 & -14.2 & 1.0 & 3.5 & & & & $\ldots$ & & $\ldots$ & $\ldots$ & $\ldots$ & \\
\hline 13 Residual, incl. change in gross foreign assets (2-3) $3 /$ & 17.6 & 26.0 & 1.0 & 2.6 & 9.1 & & & -9.3 & -2.4 & 2.6 & -1.9 & -2.4 & 0.9 & \\
\hline External debt-to-exports ratio (in percent) & 259.6 & 308.7 & 309.6 & 362.2 & 310.4 & & & 245.8 & 227.5 & 219.8 & 207.9 & 196.2 & 191.1 & \\
\hline Gross external financing need (in billions of euros) $4 /$ & 12.2 & 14.9 & 19.5 & 11.0 & 9.6 & & & 13.6 & 13.3 & 13.2 & 14.7 & 14.8 & 14.1 & \\
\hline in percent of GDP & 76.9 & 71.4 & 85.7 & 59.2 & 53.2 & 10-Year & 10-Year & 68.9 & 64.9 & 60.7 & 63.5 & 60.4 & 54.2 & \\
\hline Scenario with key variables at their historical averages $5 /$ & & & & & & & & 146.5 & 142.6 & 143.9 & 140.7 & 137.2 & 136.6 & -9.9 \\
\hline & & & & & & Historical & Standard & & & & & & & \\
\hline Key Macroeconomic Assumptions Underlying Baseline & & & & & & Average & Deviation & & & & & & & \\
\hline Real GDP growth (in percent) & 11.2 & 9.6 & -3.3 & -17.7 & -0.3 & 4.0 & 8.9 & 4.5 & 2.5 & 4.0 & 4.0 & 4.0 & 4.0 & \\
\hline GDP deflator in euros (change in percent) & 11.2 & 20.6 & 12.4 & -0.7 & -2.2 & 4.5 & 8.1 & 4.1 & 1.7 & 2.0 & 2.0 & 2.1 & 2.2 & \\
\hline Nominal external interest rate (in percent) & 3.9 & 4.7 & 4.6 & 2.9 & 2.4 & 3.2 & 0.9 & 2.8 & 2.9 & 3.0 & 3.2 & 3.3 & 3.5 & \\
\hline Growth of exports (euro terms, in percent) & 15.3 & 24.5 & 10.6 & -16.4 & 20.3 & 11.4 & 12.4 & 21.5 & 6.1 & 5.8 & 5.1 & 5.5 & 5.9 & \\
\hline Growth of imports (euro terms, in percent) & 31.3 & 23.5 & -1.7 & -35.5 & 19.4 & 10.8 & 19.0 & 23.6 & 7.0 & 6.2 & 6.1 & 6.6 & 6.9 & \\
\hline Current account balance, excluding interest payments & -19.4 & -18.4 & -7.8 & 13.2 & 6.9 & -6.4 & 10.1 & 3.9 & 3.4 & 2.9 & 2.0 & 1.1 & 0.3 & \\
\hline Net non-debt creating capital inflows & 6.5 & 6.8 & 1.4 & -2.5 & 1.2 & 3.1 & 2.7 & 3.3 & 3.4 & 3.4 & 3.4 & 3.4 & 3.5 & \\
\hline
\end{tabular}

capital inflows

$1 /$ Derived as $[r-g-\rho(1+g)+\varepsilon \alpha(1+r)] /(1+g+\rho+g \rho)$ times previous period debt stock, with $r=$ nominal effective interest rate on external debt; $\rho=$ change in domestic GDP deflator in euro terms,

$g=$ real GDP growth rate, $\varepsilon=$ nominal appreciation (increase in dollar value of domestic currency), and $\alpha=$ share of domestic-currency denominated debt in total external debt.

$2 /$ The contribution from price and exchange rate changes is defined as $[-\rho(1+g)+\varepsilon \alpha(1+r)](1+g+\rho+g \rho)$ times previous period debt stock. $\rho$ increases with an appreciating domestic currency $(\varepsilon>0)$ and rising

inflation (based on GDP deflator).

3/ For projection, line includes the impact of price and exchange rate changes.

4/ Defined as current account deficit, plus amortization on medium- and long-term debt, plus short-term debt at end of previous period

5/ The key variables include real GDP growth; nominal interest rate; dollar deflator growth; and both non-interest current account and non-debt inflows in percent of GDP.

6/ Long-run, constant balance that stabilizes the debt ratio assuming that key variables (real GDP growth, nominal interest rate, dollar deflator growth, and non-debt inflows in percent of GDP) remain at

their levels of the last projection year. 
Figure 9. Latvia: External Debt Sustainability: Bound Tests 1/ (External debt in percent of GDP)
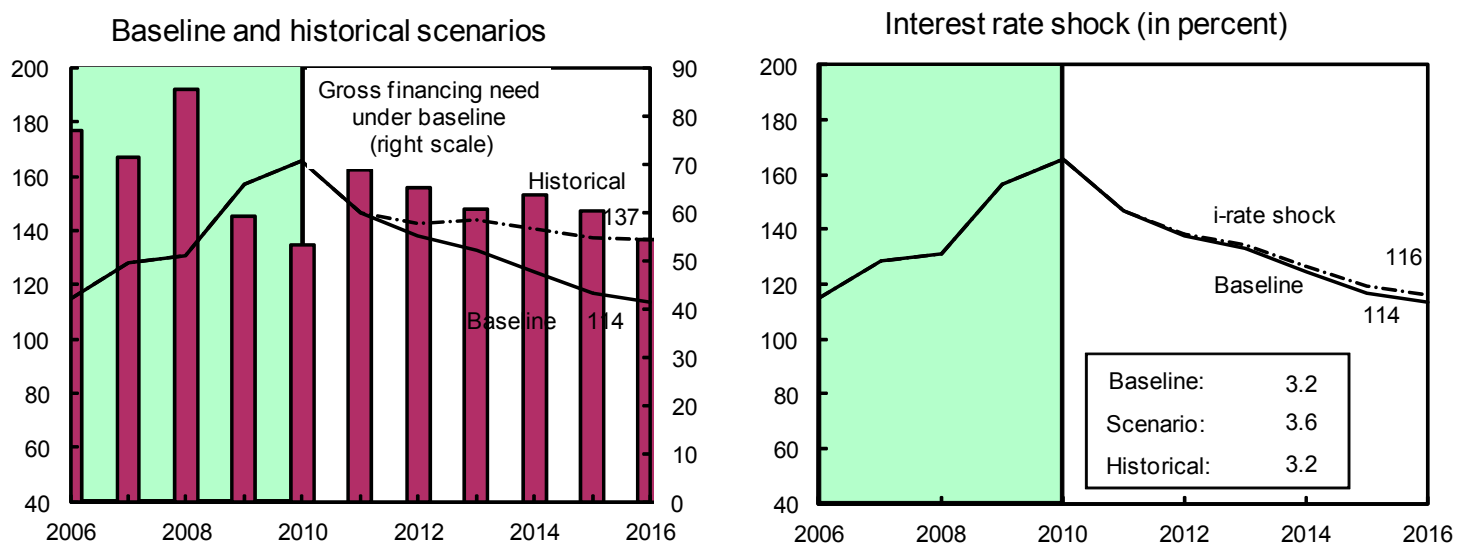

Growth shock (in percent per year)

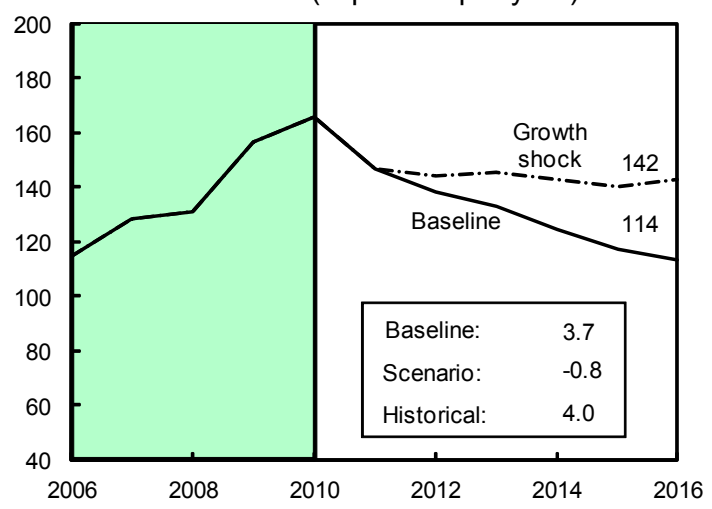

Non-interest current account shock

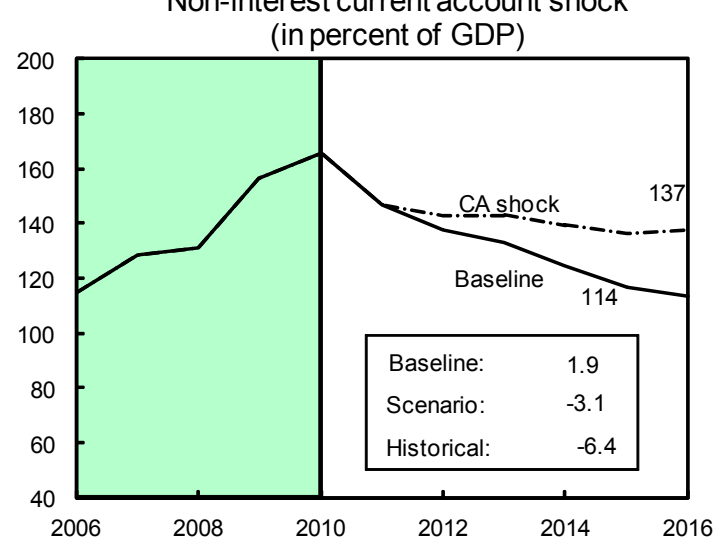

Combined shock $2 /$

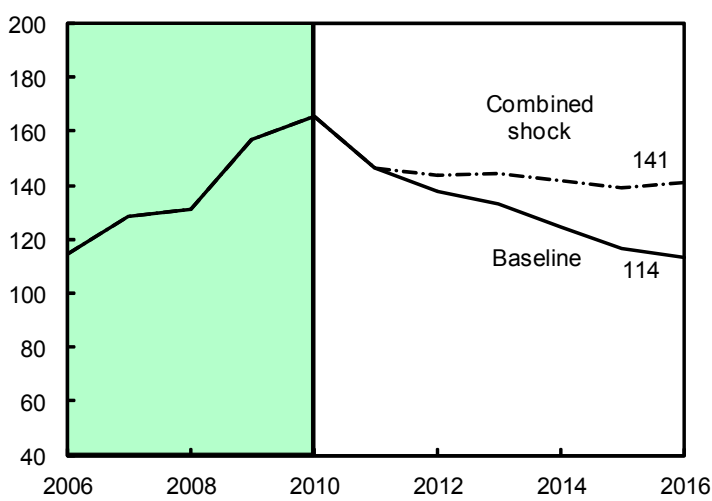

Real depreciation shock 3/

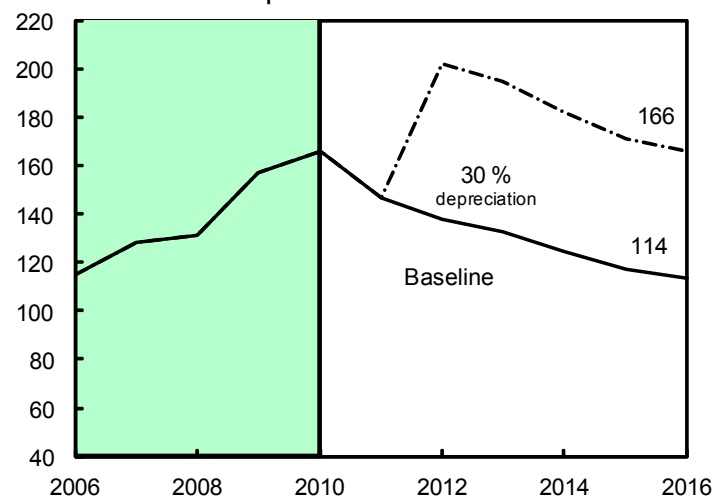

Sources: IMF staff estimates.

1/ Shaded areas represent actual data. Individual shocks are permanent one-half standard deviation shocks. Figures in the boxes represent average projections for the respective variables in the baseline and scenario being presented. Tenyear historical average for the variable is also shown.

$2 /$ Permanent $1 / 4$ standard deviation shocks applied to real interest rate, growth rate, and current account balance.

3/ One-time real depreciation of 30 percent occurs in 2011. 
Table 9. Latvia: Bank of Latvia Balance Sheet, 2008-12

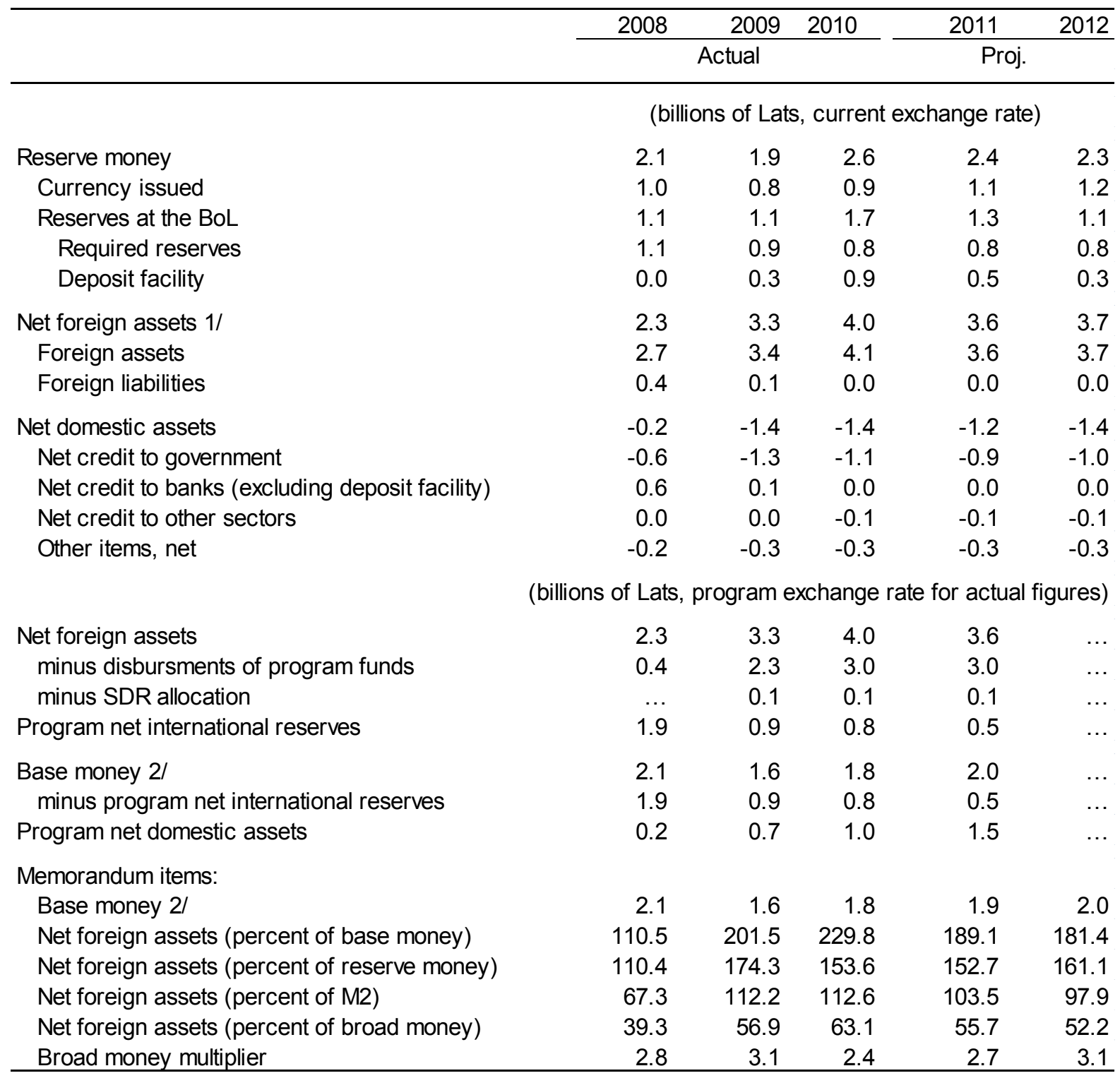

Sources: Bank of Latvia; and IMF staff estimates.

1/ Includes Treasury foreign assets deposited at the BoL

2/ Excludes banks' deposits at deposit facility 
Table 10. Latvia: Monetary Survey, 2008-12

\begin{tabular}{|c|c|c|c|c|c|}
\hline & 2008 & 2009 & 2010 & 2011 & 2012 \\
\hline & \multicolumn{3}{|c|}{ Actuals } & \multicolumn{2}{|c|}{ Proj. } \\
\hline & \multicolumn{5}{|c|}{ (billions of Lats) } \\
\hline Broad money & 5.9 & 5.8 & 6.4 & 6.5 & 7.0 \\
\hline Lats broad money (M2) & 3.5 & 3.0 & 3.6 & 3.5 & 3.7 \\
\hline Currency in circulation & 0.9 & 0.7 & 0.8 & 0.9 & 1.1 \\
\hline Lats deposits & 2.6 & 2.3 & 2.8 & 2.5 & 2.7 \\
\hline Resident foreign exchange deposits & 2.5 & 2.9 & 2.8 & 3.0 & 3.3 \\
\hline Net foreign assets & -5.9 & -3.0 & -1.2 & -0.8 & -0.3 \\
\hline Bank of Latvia & 2.3 & 3.3 & 4.0 & 3.6 & 3.7 \\
\hline Domestic money banks & -8.2 & -6.3 & -5.3 & -4.4 & -3.9 \\
\hline Net domestic assets & 11.8 & 8.8 & 7.6 & 7.2 & 7.3 \\
\hline Domestic credit & 14.3 & 12.2 & 11.2 & 10.8 & 10.7 \\
\hline Credit to government, net & -0.4 & -1.5 & -1.4 & -1.2 & -1.3 \\
\hline Credit to public corporations & 0.4 & 0.4 & 0.5 & 0.5 & 0.5 \\
\hline Credit to private sector & 14.3 & 13.3 & 12.2 & 11.5 & 11.5 \\
\hline Other items, net & -2.4 & -3.4 & -3.6 & -3.5 & -3.4 \\
\hline Sources of funds of deposit money banks & 18.2 & 16.3 & 16.4 & 15.2 & 14.9 \\
\hline Resident deposits & 5.1 & 5.2 & 5.6 & 5.5 & 5.9 \\
\hline Non-resident deposits & 3.5 & 3.3 & 4.2 & 4.6 & 5.0 \\
\hline Liabilities to foreign financial institutions & 9.3 & 7.4 & 6.5 & 5.0 & 3.9 \\
\hline Other foreign liabilities & 0.4 & 0.6 & 0.1 & 0.1 & 0.1 \\
\hline Uses of funds of deposit money banks & 18.2 & 16.3 & 16.4 & 15.2 & 14.9 \\
\hline Reserves & 1.2 & 1.2 & 1.8 & 1.4 & 1.2 \\
\hline Cash in vault & 0.2 & 0.1 & 0.1 & 0.1 & 0.1 \\
\hline Required reserves & 1.1 & 0.9 & 0.8 & 0.8 & 0.8 \\
\hline Deposit facility & 0.0 & 0.3 & 0.9 & 0.5 & 0.3 \\
\hline Domestic credit & 14.3 & 13.4 & 12.3 & 11.6 & 11.7 \\
\hline Foreign assets & 4.9 & 4.9 & 5.6 & 5.4 & 5.0 \\
\hline \multirow[t]{2}{*}{ Other items, net } & -2.2 & -3.1 & -3.3 & -3.2 & -3.1 \\
\hline & \multicolumn{5}{|c|}{ (annual percentage change) } \\
\hline Broad money & -3.9 & -1.9 & 9.8 & 1.1 & 8.3 \\
\hline Net foreign assets & -31.9 & 48.9 & 59.6 & 37.8 & 63.3 \\
\hline Bank of Latvia & -16.0 & 42.1 & 21.7 & -10.7 & 1.4 \\
\hline Domestic money banks & -13.6 & 23.2 & 17.1 & 17.0 & 9.9 \\
\hline Net domestic assets & 11.2 & -25.4 & -13.9 & -5.1 & 0.8 \\
\hline Domestic credit & 9.7 & -14.5 & -8.1 & -4.0 & -0.6 \\
\hline Credit to government, net & -323.3 & -298.5 & 2.9 & 18.0 & -7.0 \\
\hline Credit to public corporations & 52.5 & 3.8 & 19.9 & -4.4 & 0.0 \\
\hline \multirow[t]{2}{*}{ Credit to private sector } & 11.0 & -6.9 & -8.4 & -5.6 & 0.1 \\
\hline & \multicolumn{5}{|c|}{ (percent of GDP, unless otherwise indicated) } \\
\hline \multicolumn{6}{|l|}{ Memorandum items: } \\
\hline Lats broad money (M2) & 21.6 & 22.6 & 28.1 & 25.2 & 25.9 \\
\hline Broad money & 36.9 & 44.5 & 50.2 & 46.8 & 48.6 \\
\hline Currency in circulation & 5.4 & 5.1 & 6.3 & 6.8 & 7.4 \\
\hline Residents' FX deposits (percent of total deposits) & 48.6 & 55.6 & 50.3 & 54.0 & 55.1 \\
\hline Domestic credit & 88.8 & 93.4 & 88.0 & 78.1 & 74.3 \\
\hline Private sector credit & 88.7 & 101.6 & 95.5 & 83.3 & 79.9 \\
\hline Nominal GDP (billions of lats) & 16.1 & 13.1 & 12.7 & 13.8 & 14.4 \\
\hline
\end{tabular}

Sources: Bank of Latvia; and IMF staff estimates. 
Table 11. Latvia: Financial Soundness Indicators, 2007-2011

(In percent, unless otherwise indicated)

\begin{tabular}{|c|c|c|c|c|c|}
\hline & Dec-07 & Dec-08 & Dec-09 & Dec-10 & Sep-11 \\
\hline \multicolumn{6}{|l|}{ Commercial banks } \\
\hline \multicolumn{6}{|l|}{ Capital Adequacy } \\
\hline Regulatory capital to risk-weighted assets & 11.1 & 11.8 & 14.6 & 14.6 & 17.0 \\
\hline Regulatory Tier I capital to risk-weighted assets $1 /$ & 9.8 & 10.5 & 11.5 & 11.5 & 14.0 \\
\hline Capital and reserves to assets & 7.9 & 7.3 & 7.4 & 7.3 & 8.7 \\
\hline \multicolumn{6}{|l|}{ Asset Quality } \\
\hline Annual growth of bank loans & 37.2 & 11.2 & -7.0 & -7.1 & -8.2 \\
\hline Loans past due over 90 days & 0.8 & 3.6 & 16.4 & 19.0 & 18.0 \\
\hline Loans past due over 90 days net of loan loss provisions to capital & & 13.6 & 67.6 & 65.3 & 47.6 \\
\hline Loan loss provisions to loans past due over 90 days & & 61.3 & 57.4 & 61.6 & 64.6 \\
\hline Loan loss provisions to total loans & & 2.2 & 9.4 & 11.7 & 11.6 \\
\hline Share of loans in total assets, banks dealing with residents $2 /$ & 80.4 & 82.5 & 76.4 & 74.7 & 77.4 \\
\hline Share of loans in total assets, banks dealing with non-residents $2 /$ & 48.9 & 51.7 & 52.4 & 46.4 & 42.1 \\
\hline \multicolumn{6}{|l|}{ Earnings and Profitability } \\
\hline ROA (after tax) & 2.0 & 0.3 & -3.5 & -1.6 & 0.5 \\
\hline ROE (after tax) & 24.3 & 4.6 & -41.6 & -20.4 & 5.2 \\
\hline Net interest income to total income & 32.5 & 30.1 & 23.3 & 19.0 & 20.2 \\
\hline Noninterest expenses to total income & 32.3 & 47.5 & 114.5 & 93.5 & 67.9 \\
\hline Trading income to total income & 7.8 & 5.6 & 8.6 & 5.4 & 6.1 \\
\hline Personnel expenses to noninterest expenses & 31.5 & 21.3 & 8.5 & 11.9 & 14.5 \\
\hline \multicolumn{6}{|l|}{ Income from operations with non-residents to total income } \\
\hline Banks dealing with residents $2 /$ & 13.0 & 13.7 & 21.0 & 25.7 & 18.8 \\
\hline Banks dealing with non-residents $2 /$ & 49.2 & 48.0 & 44.8 & 46.6 & 53.4 \\
\hline \multicolumn{6}{|l|}{ Liquidity } \\
\hline Liquid assets to total assets & 25.0 & 21.6 & 21.1 & 27.3 & 25.9 \\
\hline Liquid assets to short term liabilities & 55.7 & 52.8 & 62.8 & 67.9 & 60.1 \\
\hline Customers deposits to (non-interbank) loans & 68.2 & 58.8 & 61.9 & 77.5 & 83.4 \\
\hline \multicolumn{6}{|l|}{ Sensitivity to Market Risk } \\
\hline Net open positions in FX to capital 3/ & 5.4 & 6.3 & $4.1^{*}$ & $4.2^{*}$ & $2.8^{*}$ \\
\hline Net open positions in EUR to capital & 3.2 & 3.7 & $3.0^{*}$ & $2.8^{*}$ & $2.2^{*}$ \\
\hline FX assets to total assets & 79.7 & 80.5 & 82.7 & 80.6 & 80.3 \\
\hline FX deposits to total deposits & 70.7 & 69.4 & 74.5 & 72.6 & 74.8 \\
\hline FX liabilities to total liabilities $3 /$ & 81.7 & 81.1 & 83.8 & 81.6 & 81.3 \\
\hline FX loans to total loans $3 /$ & 81.8 & 85.0 & 87.1 & 88.9 & 86.8 \\
\hline \multicolumn{6}{|l|}{ Nonfinancial Enterprises 4/ } \\
\hline Total debt to equity & 202.0 & 217.6 & 281.2 & $226.5^{\star *}$ & $\ldots$ \\
\hline Return on equity & 31.1 & 14.4 & 1.7 & $8.4^{\star *}$ & $\ldots$ \\
\hline Earnings to interest expenses & 496.7 & 225.9 & 24.1 & 169.6 & $\cdots$ \\
\hline \multicolumn{6}{|l|}{ Households } \\
\hline Household debt to GDP & 42.4 & 41.1 & 48.1 & 46.3 & 40.7 \\
\hline Household debt service to GDP 5/ & 2.48 & 2.72 & 2.52 & 1.97 & 1.70 \\
\hline \multicolumn{6}{|l|}{ Real Estate Markets } \\
\hline Real estate prices annual growth rate $6 /$ & -7.3 & -37.1 & -39.6 & 7.6 & -0.7 \\
\hline Residential real estate loans to total loans $7 /$ & 31.6 & 30.5 & 31.3 & 32.1 & 31.9 \\
\hline Commercial real estate loans to total loans $7 /$ & 17.8 & 19.5 & 19.9 & 18.0 & $\ldots$ \\
\hline \multicolumn{6}{|l|}{ Memorandum Items } \\
\hline Number of banks dealing with residents $2 /$ & 9 & 14 & 15 & 15 & 18 \\
\hline Number of banks dealing with non-residents $2 /$ & 14 & 13 & 12 & 14 & 13 \\
\hline Assets of banks dealing with residents/Total banking system assets $2 /$ & 60.8 & 63.9 & 78.4 & 66.6 & 65.0 \\
\hline Assets of banks dealing with non-residents/Total banking system assets $2 /$ & 39.2 & 36.1 & 21.6 & 33.4 & 35.0 \\
\hline
\end{tabular}

Sources: Latvian authorities; and IMF staff estimates.

*Excluding Parex Bank.

** September 2010.

1/ Regulatory Tier 1 capital to risk weighted assets as from December 2009 is calculated as Tier 1 capital (including deduction)/risk-weighted assets.

2/ Banks dealing with residents (non-residents) are defined as banks in which non-resident non-MFI deposits are below (above)

20 percent of their assets.

3/ Including euro-denominated positions.

4/ Data is not annualized and not comparable to yearly figures due to different sample (for 3, 6, 9 and 12 months respectively);

Starting from Q2 2010 data used in calculatons is adjusted to full coverage of the nonfinancial enterprises.

$5 /$ Interest payments only.

6/ Prices of typical standard apartments in Riga. Source: Real estate company Latio.

7/ Loans to residents only to total loans (including loans to non-residents). 
Table 12. Latvia: Selected Vulnerability Indicators, 2007-11

\begin{tabular}{|c|c|c|c|c|c|c|}
\hline & 2007 & 2008 & 2009 & 2010 & $20111 /$ & $\begin{array}{c}\text { Latest } \\
\text { Observation }\end{array}$ \\
\hline \multicolumn{7}{|l|}{ Key economic and market indicators } \\
\hline Real GDP growth (y-o-y, percent) & 9.6 & -3.3 & -17.7 & -0.3 & 5.0 & Q2, 2011 \\
\hline HICP inflation (period average, percent) & 10.1 & 15.3 & 3.3 & -1.2 & 4.3 & Oct-11 \\
\hline Short-term (ST) interbank rate, 1-month RIGIBOR (eop, percent) & 6.8 & 13.3 & 2.7 & 0.6 & 0.5 & Oct-11 \\
\hline Eurobond secondary market spread (bps, eop) & 74 & 648 & 505 & 307 & 417 & Nov-11 \\
\hline Exchange rate (lats per U.S. dollar, eop) & 0.48 & 0.50 & 0.49 & 0.54 & 0.52 & Nov-11 \\
\hline Exchange rate (lats per U.S. dollar, period average) & 0.51 & 0.48 & 0.51 & 0.53 & 0.52 & Nov-11 \\
\hline \multicolumn{7}{|l|}{ External sector } \\
\hline Exchange rate regime & \multicolumn{4}{|c|}{ Pegged to the euro $(+/-1 \%$ band $)$} & & \\
\hline Current account balance (percent of GDP) & -22.4 & -13.2 & 8.7 & 3.0 & $\ldots$ & Q4, 2010 \\
\hline Net FDI inflows (percent of GDP) & 6.8 & 3.1 & 0.6 & 1.5 & $\ldots$ & Q4, 2010 \\
\hline Exports (percentage change of US\$ value) & 35.9 & 18.8 & -20.9 & 14.6 & 21.9 & Sep-11 \\
\hline Real effective exchange rate index $(2000=100$, period average $)$ & 95.1 & 104.5 & 110.3 & 103.6 & 105.3 & Oct-11 \\
\hline Gross international reserves (GIR, US\$ billion) & 5.8 & 5.0 & 7.0 & 7.7 & 7.9 & Oct-11 \\
\hline $\begin{array}{l}\text { GIR in percent of ST debt at remaining maturity (RM) excluding non- } \\
\text { resident deposits }\end{array}$ & 215.9 & 160.7 & 282.9 & 311.8 & $\ldots$ & Q4, 2010 \\
\hline GIR in percent of ST debt at RM including banks' non-resident FX deposits & 34.2 & 37.2 & 67.0 & 83.0 & $\ldots$ & Q4, 2010 \\
\hline Net international reserves (NIR, US\$ billion) & 5.7 & 3.9 & 2.0 & 1.6 & 1.5 & Nov-11 \\
\hline Total gross external debt (ED, percent of GDP) & 128.1 & 130.0 & 156.5 & 165.2 & $\ldots$ & Q4, 2010 \\
\hline ST external debt (original maturity, percent of total ED) & 43.2 & 33.5 & 24.6 & 32.6 & 30.8 & Q2, 2011 \\
\hline ED of domestic private sector (percent of total ED) & 96.0 & 91.6 & 83.5 & 79.9 & 78.4 & Q2, 2011 \\
\hline Total gross external debt (percent of exports) & 438.4 & 437.5 & 514.4 & 444.1 & $\ldots$ & Q4, 2010 \\
\hline Gross external financing requirement (US\$ billion) 2/ & 14.0 & 24.2 & 17.5 & 13.5 & $\cdots$ & Q4, 2010 \\
\hline \multicolumn{7}{|l|}{ Public sector (PS) 3/ } \\
\hline Basic balance (excluding bank restructuring costs; percent of GDP) & 0.6 & -3.4 & -7.1 & -6.4 & $\ldots$ & Q4, 2010 \\
\hline Primary basic balance (percent of GDP) & 1.0 & -3.0 & -5.9 & -5.0 & $\ldots$ & Q4, 2010 \\
\hline Gross PS financing requirement (percent of GDP) 4/ & 0.3 & 8.9 & 15.9 & 12.6 & $\ldots$ & Q4, 2010 \\
\hline General government gross debt (percent of GDP) & 7.8 & 17.2 & 32.9 & 39.9 & $\ldots$ & Q4, 2010 \\
\hline \multicolumn{7}{|l|}{ Financial sector (FS) $5 /$} \\
\hline Capital adequacy ratio (percent) & 11.1 & 11.8 & 14.6 & 14.6 & 17.0 & Sep-11 \\
\hline Overdue loans (percent of total loans) 6/ & 0.8 & 3.6 & 16.4 & 19.0 & 18.0 & Sep-11 \\
\hline Provisions (percent of overdue loans) & 64.9 & 61.3 & 57.4 & 61.6 & 64.6 & Sep-11 \\
\hline Return on average assets (percent) & 2.0 & 0.3 & -3.5 & -1.6 & 0.5 & Sep-11 \\
\hline Return on equity (percent) & 24.2 & 4.6 & -41.6 & -20.4 & 5.2 & Sep-11 \\
\hline Residents' FX deposits (percent of total resident deposits) & 70.7 & 69.4 & 74.5 & 72.6 & 74.8 & Sep-11 \\
\hline FX loans to residents (percent of total loans to residents) & 81.8 & 85.0 & 87.1 & 88.9 & 86.8 & Sep-11 \\
\hline Credit to private sector (percent change, year-on-year) 7/ & 33.0 & 11.0 & -6.9 & -8.4 & -8.1 & Sep-11 \\
\hline \multicolumn{7}{|l|}{ Memorandum item: } \\
\hline Nominal GDP (billions of U.S. dollars) & 28.7 & 33.5 & 25.9 & 24.0 & 7.0 & Q2, 2011 \\
\hline
\end{tabular}

Sources: Latvian authorities; and IMF staff estimates.

1/ Latest observations as indicated in the last column.

2/ Current account deficit plus amortization of external debt.

3/ Public sector covers general government.

4/ Overall balance plus debt amortization.

$5 /$ Financial sector includes commercial banks.

6/ 90-days overdue.

7/ Total loans less loans to the public sector and transit loans, provided to both residents and non-residents. 
Table 13. Latvia: Proposed Schedule of Reviews and Purchases

\begin{tabular}{lccll}
\hline & \multicolumn{2}{c}{ Amount of purchase } & \\
\cline { 2 - 3 } Date 1/ & Millions of SDRs & Percent of quota & Conditions \\
\hline December 29, 2008 & 535.344 & 376.7 & Approval of arrangement \\
August 31, 2009 & 178.448 & 125.6 & & $\begin{array}{l}\text { First review, end-March 2009 performance criteria } \\
\text { February 19, 2010 }\end{array}$ \\
& 178.448 & 125.6 & & $\begin{array}{l}\text { Second review and end-September 2009 fiscal performance criteria and end- } \\
\text { December 2009 monetary performance criteria }\end{array}$ \\
August 12, 2010 & 90.000 & 63.3 & & $\begin{array}{l}\text { Third review and end-March 2010 fiscal performance criteria and end-June } \\
\text { monetary performance criteria }\end{array}$ \\
May 15, 2011 & 107.877 & 75.9 & & Fourth review and end-December 2010 performance criteria \\
December 21, 2011 & 431.509 & 303.7 & Fifth review and end-August 2011 performance criteria \\
Total & 1521.626 & 1070.8 & \\
\hline
\end{tabular}

Source: IMF staff estimates.

1/ For past purchases, actual dates are shown. For potential future purchases, the earliest possible dates are shown. 
Table 14. Latvia: Program Financing, 2010-11 (Millions of euros)

\begin{tabular}{|c|c|c|c|c|c|c|c|c|c|}
\hline & \multicolumn{4}{|c|}{2010} & \multicolumn{4}{|c|}{2011} & \multirow{2}{*}{$\begin{array}{c}2010 Q 1 \text { to } \\
2011 Q 4\end{array}$} \\
\hline & \multirow[t]{2}{*}{ Mar. } & \multirow[t]{2}{*}{ Jun. } & \multirow[t]{2}{*}{ Sep. } & \multirow[t]{2}{*}{ Dec. } & \multirow[t]{2}{*}{ Mar. } & \multirow[t]{2}{*}{ Jun. } & Sep. & Dec. & \\
\hline & & & & & & & \multicolumn{2}{|c|}{ Projections } & Proj. \\
\hline Total financing requirements & 1,624 & 467 & 357 & 1,209 & 458 & 1,416 & 1,004 & 1,034 & 7,568 \\
\hline Amortizing debt & 1,201 & 822 & 347 & 76 & 910 & 1,241 & 950 & 494 & 6,041 \\
\hline Other sectors & -42 & 153 & -24 & 198 & 146 & 146 & 146 & 146 & 869 \\
\hline Banks & 1,243 & 669 & 372 & -122 & 764 & 1,095 & 803 & 347 & 5,172 \\
\hline Short term liabilities & 597 & -297 & 251 & -17 & 21 & 14 & 0 & 0 & 569 \\
\hline Trade credit (net) & -138 & 21 & -124 & 5 & 98 & -80 & 6 & 9 & -203 \\
\hline Resident FX accumulation & -36 & -79 & -117 & 1,146 & -572 & 241 & 48 & 531 & 1,162 \\
\hline Total financing sources & 929 & 467 & 151 & 909 & 459 & 1,418 & 1,005 & 935 & 6,275 \\
\hline Current account & 350 & 245 & -16 & -39 & 47 & 45 & -65 & -96 & 471 \\
\hline Direct investment (net) & -80 & 85 & 104 & 161 & 246 & 249 & 188 & 125 & 1,078 \\
\hline Portfolio investment and financial derivatives (net) & 1 & -90 & -21 & -223 & -430 & 287 & -260 & 539 & -197 \\
\hline o/w government eurobond & 0 & 0 & 0 & 0 & 0 & 369 & 0 & 0 & 369 \\
\hline Capital account & 138 & 63 & 97 & 55 & 5 & 21 & 323 & 189 & 890 \\
\hline Other & 1,161 & -68 & 452 & 807 & 285 & 1,006 & 1,080 & -574 & 4,150 \\
\hline Change in gross reserves (+ denotes decline) & -641 & 232 & -465 & 149 & 306 & -190 & -260 & 752 & -118 \\
\hline Financing gap & 694 & 0 & 206 & 300 & -2 & -1 & -1 & 99 & 1,294 \\
\hline Official financing & 694 & 0 & 206 & 300 & -2 & -1 & -1 & 99 & 1,294 \\
\hline IMF & 194 & 0 & 106 & 0 & 0 & 0 & 0 & 0 & 300 \\
\hline EU & 500 & 0 & 0 & 200 & 0 & 0 & 0 & 0 & 700 \\
\hline Nordics & 0 & 0 & 0 & 0 & 0 & 0 & 0 & 0 & 0 \\
\hline World Bank & 0 & 0 & 100 & 100 & -2 & -1 & -1 & 99 & 294 \\
\hline Czech Republic & 0 & 0 & 0 & 0 & 0 & 0 & 0 & 0 & 0 \\
\hline EBRD & 0 & 0 & 0 & 0 & 0 & 0 & 0 & 0 & 0 \\
\hline Poland & 0 & 0 & 0 & 0 & 0 & 0 & 0 & 0 & 0 \\
\hline \multicolumn{10}{|l|}{ Memorandum Item } \\
\hline Lines of credit (cumulative stocks) & 0 & 0 & 750 & 750 & 750 & 850 & 850 & 1,400 & 1,400 \\
\hline Nordics & 0 & 0 & 550 & 550 & 550 & 550 & 550 & 1,100 & 1,100 \\
\hline Czech Republic 1/ & 0 & 0 & 100 & 100 & 100 & 200 & 200 & 200 & 200 \\
\hline Poland 1/ & 0 & 0 & 100 & 100 & 100 & 100 & 100 & 100 & 100 \\
\hline
\end{tabular}

Source: IMF staff estimates.

$1 /$ Loan agreements not yet signed. 
Table 15. Latvia: Indicators of Fund Credit, 2009-16 (millions of SDRs)

\begin{tabular}{|c|c|c|c|c|c|c|c|c|}
\hline & 2009 & 2010 & 2011 & 2012 & 2013 & 2014 & 2015 & 2016 \\
\hline Stock, existing $1 /$ & 713.8 & 982.2 & 982.2 & 692.3 & 257.2 & 56.1 & 0.0 & 0.0 \\
\hline Stock, existing and prospective $1 /$ & 713.8 & 982.2 & 1521.6 & 1231.6 & 796.6 & 595.4 & 269.7 & 0.0 \\
\hline Obligations, existing & 11.2 & 21.8 & 20.4 & 312.3 & 447.1 & 203.6 & 56.4 & 0.0 \\
\hline Repurchase & 0.0 & 0.0 & 0.0 & 290.0 & 435.1 & 201.1 & 56.1 & 0.0 \\
\hline Charges & 11.2 & 21.8 & 20.4 & 22.3 & 12.0 & 2.5 & 0.3 & 0.0 \\
\hline Obligations, existing and prospective & 11.2 & 21.8 & 23.1 & 327.3 & 464.4 & 217.7 & 334.6 & 272.3 \\
\hline Repurchase & 0.0 & 0.0 & 0.0 & 290.0 & 435.1 & 201.1 & 325.8 & 269.7 \\
\hline Charges & 11.2 & 21.8 & 23.1 & 37.3 & 29.3 & 16.6 & 8.9 & 2.6 \\
\hline \multicolumn{9}{|l|}{ Stock of existing Fund credit } \\
\hline In percent of quota & 502.3 & 691.2 & 691.2 & 487.2 & 181.0 & 39.5 & 0.0 & 0.0 \\
\hline In percent of GDP & 4.3 & 6.2 & 5.6 & 3.8 & 1.3 & 0.3 & 0.0 & 0.0 \\
\hline In percent of exports of goods and services & 9.8 & 11.7 & 9.4 & 6.3 & 2.2 & 0.5 & 0.0 & 0.0 \\
\hline In percent of gross reserves & 16.1 & 19.7 & 21.3 & 14.9 & 4.5 & 1.0 & 0.0 & 0.0 \\
\hline \multicolumn{9}{|l|}{ Stock of existing and prospective Fund credit } \\
\hline In percent of quota & 502.3 & 691.2 & 1070.8 & 866.7 & 560.6 & 419.0 & 189.8 & 0.0 \\
\hline In percent of GDP & 4.3 & 6.2 & 8.7 & 6.8 & 4.1 & 2.9 & 1.3 & 0.0 \\
\hline In percent of exports of goods and services & 9.8 & 11.7 & 14.6 & 11.2 & 6.9 & 4.9 & 2.1 & 0.0 \\
\hline In percent of gross reserves & 16.1 & 19.7 & 33.0 & 26.5 & 14.0 & 10.4 & 4.9 & 0.0 \\
\hline \multicolumn{9}{|l|}{ Obligations to the Fund from existing Fund drawings } \\
\hline In percent of quota & 7.8 & 15.3 & 14.3 & 219.8 & 314.6 & 143.3 & 39.7 & 0.0 \\
\hline In percent of GDP & 0.1 & 0.1 & 0.1 & 1.7 & 2.3 & 1.0 & 0.3 & 0.0 \\
\hline In percent of exports of goods and services & 0.2 & 0.3 & 0.2 & 2.8 & 3.9 & 1.7 & 0.4 & 0.0 \\
\hline In percent of gross reserves & 0.3 & 0.4 & 0.4 & 6.7 & 7.8 & 3.6 & 1.0 & 0.0 \\
\hline \multicolumn{9}{|c|}{ Obligations to the Fund from existing and prospective Fund drawings } \\
\hline In percent of quota & 7.8 & 15.3 & 16.2 & 230.3 & 326.8 & 153.2 & 235.5 & 214.7 \\
\hline In percent of GDP & 0.1 & 0.1 & 0.1 & 1.8 & 2.4 & 1.1 & 1.6 & 1.2 \\
\hline In percent of exports of goods and services & 0.2 & 0.3 & 0.2 & 3.0 & 4.0 & 1.8 & 2.6 & 2.0 \\
\hline In percent of gross reserves & 0.3 & 0.4 & 0.5 & 7.0 & 8.1 & 3.8 & 6.1 & 0.0 \\
\hline
\end{tabular}

Source: IMF staff estimates.

1/ End-period. The authorities have indicated their intention of treating the purchases associated with Fifth Review as precautionary. "Existing and prospective" assumes that this amount is drawn. 
LATVIA: LETTER OF INTENT

Riga, December 8, 2011

Ms. Christine Lagarde

Managing Director

International Monetary Fund

Washington, D.C. 20431

Dear Ms. Lagarde:

1. Our economic program has achieved its main objectives. After an unprecedented decline, economic growth is resuming, inflation remains under control, and unemploymentalthough still high - is declining steadily. We have preserved our fixed (narrow band) exchange rate, stabilized the financial sector, and improved competitiveness through declines in wages and prices, productivity improvements, and structural adjustment. We have also lowered our budget deficit, started work on policies that will preserve long-term fiscal sustainability, and introduced significant reforms to improve private debt restructuring, tax administration, management of state-owned enterprises, and to combat the grey economy. These policies will boost Latvia's growth in the medium term, and put us on a clear path towards euro adoption. To maintain our reform momentum, we will continue to work with the Fund towards these goals under Post Program Monitoring.

2. We remain committed to implementing our economic program. Since the Fourth Review we have:

- Comfortably met all end-August performance criteria as well as end-June and end-September indicative targets. Excluding one-off financial sector costs, we expect to achieve a fiscal deficit of around 4 percent of GDP (ESA terms) in 2011 (Table 1), well below our 4.5 percent of GDP program target.

- Met most of our financial sector structural benchmarks, though with delay. For Mortgage and Land Bank (MLB), we hired a sales consultant, prepared a sales strategy, and on November 2 submitted this to the European Commission (although this was originally due end-June). We are soliciting bids for the bank's commercial assets and intend to sign sales contracts with bidders by March 2012. After discussions with stakeholders, we have withdrawn our initial proposal to amend the Civil Procedure Law to address unpaid utility bills, and have instead introduced changes which make it easier and faster for utility companies to pursue their claims.

- Met most of our fiscal structural benchmarks, and made significant progress towards fulfilling the rest. We submitted a revised draft of the Fiscal Discipline Law (FDL) to Parliament on December 6, though submitting constitutional amendments to make the law effective will take more time. We have prepared a strategy to improve 
management of state-owned enterprises (SOEs), which will be submitted to Cabinet by mid-December; and we finalized a new strategy on Active Labor Market Policies (ALMP). New elections delayed preparation of the menu of options for the 2012 budget and the budget itself, but we plan to submit this to Parliament by

December 7, 2011. We will continue to work to improve our tax compliance strategy and to combat the shadow economy and we recognize that more effort is required in these areas.

3. We will further strengthen our macroeconomic and fiscal policies to lay solid groundwork for our goal of euro adoption in 2014. In 2012, we will reduce the fiscal deficit to no more than 2.5 percent of GDP (ESA terms), to meet our aims of fulfilling the ECOFIN Council recommendation to correct the excessive deficit position and of meeting the Maastricht deficit criterion. We intend to take measures that will support a low inflation environment in Latvia and help us meet the Maastricht inflation criterion in a sustainable way. These include sustainable and countercyclical fiscal policy, which will be implemented under the umbrella of the FDL, and the medium term budgeting law, which we plan to submit to Parliament no later than six months after the FDL has been adopted. Additionally, we intend to launch reforms that will promote competition, increase price transparency in local markets, and reduce structural unemployment. We will try to avoid further tax increases.

4. Looking ahead, our new government will implement a series of structural reforms to ensure that Latvia's economy stays competitive and its long-term growth is sustainable. To this end we intend to:

- Improve the business environment and ensure the efficient use of EU structural funds and adequate access to finance for companies.

- $\quad$ Continue to implement measures to reduce structural unemployment by ensuring better matching in the labor market.

- $\quad$ Continue to reform the education system, to improve the quality and international competitiveness of educational institutions, and to better link higher and vocational education with labor market demands.

5. In light of our strong performance and the policies outlined in this letter, we request completion of the Fifth Review and Financing Assurances Review under the Stand-by Arrangement. In late-November, following the discovery of fraud in Krajbanka, we decided to introduce a temporary restriction on all payments (including deposits) in the bank. The operations of the bank were suspended on November 21 and insolvency proceedings are being initiated. We request a waiver for nonobservance of the continuous performance criterion against imposing or intensifying restrictions on the making of payments and transfers for current international transaction, on the grounds that this 
restriction was temporary and has now been removed. Given our continued strong financial position, we do not intend to draw the funds available to us in this review.

\section{We authorize the IMF to publish this Letter of Intent and its attachments, and the related staff report.}

\section{MACroeconomic Framework}

\section{The economy expanded vigorously in the second quarter, but the likely} slowdown in the world economy poses new challenges. With private consumption and investment rebounding in the first half of the year, we have revised our growth forecast this year to 4.5 percent. However, the projected stagnation in trading partners' growth later this year and into next year could cause some weakening in exports, domestic confidence, consumption, and investment. Though we hope that the actual outturn will be better, we believe that our macroeconomic framework for 2012 is prudent, and is based on GDP growth slowing to 2.5 percent. Lower exports and the need to import essential goods are expected to push the current account into a slight deficit. While labor market conditions should continue to improve gradually, we project a modest decline in the unemployment rate (ages $15-74$ ), from 15.8 percent this year to 14.6 percent next year. With long-term unemployment more than half the total, skill loss and skill mismatch are a particular concern.

\section{Inflation should decelerate, helped by moderating domestic demand and a} reversal of this year's increase in world food and energy prices. Although CPI inflation this year should average 4.4 percent, in 2012 it should fall to around 2.4 percent. This should be sufficient to meet the Maastricht inflation criteria in mid-2013, although risks remain. We intend to monitor price developments carefully based on our quarterly macroeconomic projections (Table 2), and to take action to promote a low-inflation environment.

9. Nominal wages have declined and productivity has increased. As a result, real unit labor costs have fallen although wages have picked up moderately in 2011 partly driven by the increase in the minimum wage. Taking 2000 as the base year, the gap between real wages and productivity that widened considerably during the boom years has closed, providing a boost to Latvia's cost competitiveness. Even though the improvement in competitiveness has stalled somewhat, the real exchange rate has depreciated significantly from its pre-crisis peak. In order to secure further competitiveness gains, we will continue implementing our structural reform agenda, including the measures listed in $\uparrow 4$.

\section{Fiscal Policy}

10. We are on track to meet the 4.5 percent GDP fiscal deficit target for 2011 set in the previous LOI. We comfortably met the end-August performance criterion and the end-June and end-September indicative targets due to stronger than expected direct taxes, and savings in the social budget. We executed all budgetary spending as planned, though we were forced to use all budgetary funds for unforeseen events to support underestimated 
structural spending for state family benefits, health care services, and road maintenance. We also allocated extra funds to cover increasing demand for social safety net spending. We intend to use the remaining budgetary space to frontload the fiscal costs associated with the recapitalization of MLB. Additional funds will also be used to recapitalize airBaltic.

\section{We are adopting a 2012 budget which cuts the deficit to 2.5 percent of GDP in a} sustainable way, with quarterly projections for revenues, expenditures and the deficit shown in Table 2. This will be achieved through the following measures, which total L110 million (approximately 0.8 percent of GDP):

\section{Revenue (L39 million-0.3 percent of GDP):}

- $\quad$ Broaden the real estate tax base to: (i) include auxiliary buildings (larger than $25 \mathrm{~m}^{2}$ ), houses and land for religious organizations not used for religious purpose, and parking lots (L0.5 million); and (ii) give municipalities the option of abolishing the 25 percent upper limit on the annual increase in the real estate tax on land (L3.5 million).

- $\quad$ Broaden the VAT base by applying reverse VAT on scrap metal and construction activities (L5.9 million).

- Apply a 10 percent withholding personal income tax on sales of scrap metal (L3.7 million).

- $\quad$ Strengthen the presumptive taxation of small and micro enterprises by ensuring that the general personal income tax regime is applicable to personnel provided by large companies to microenterprises to minimize their tax liability (L2.7 million).

- Improve tax compliance by: (i) cancelling interest and fines on unpaid taxes to facilitate the collection of those tax claims (L15 million); (ii) reducing the taxfree movement of excise goods on the non-EU border from daily to weekly (L1.5 million); (iii) increase the gambling tax on slot machines and game tables by 15 percent (L2.2 million); (iv) strengthening the regulation of the gambling industry (L0.7); and (v) ensuring higher tax collection by increasing the resources assigned to the State Revenue Service (L1.2 million).

- Increase the financial stability levy from 0.036 to 0.072 percent (L2.3 million).

- $\quad$ Expenditures and net lending (L71 million-0.5 percent of GDP):

- $\quad$ Cut subsidies and grants for sports and agriculture (L7.5 million).

- $\quad$ Reduce the grant for Riga International Airport (L0.2 million). 
- $\quad$ Reduce local government spending by: (i) further restricting local government borrowing (L20 million), while extending the borrowing capacity to investment projects not co-financed from EU funds; (ii) reduce the share of personal income tax redirected to local government budgets from 82 to 80 percent, while safeguarding transfers to less prosperous local governments and continuing to co-finance 50 percent of GMI benefits through 2012 (L10 million); and (iii) reduce the central government's share in co-financing of housing benefits for local governments from 20 to zero percent from endApril 2012 (L2.5 million).

- $\quad$ Reduce road maintenance costs and subsidies for public transportation providers (L10 million and L5 million, respectively).

- $\quad$ Reduce expenditures at the Ministry of Defense (L6.6 million), the Ministry of Interior (L1.2 million), and the Ministry of Health (L2.7 million), and reduce financing for the National Library to reflects delays in construction (L2.5 million).

- $\quad$ Reduce expenditures at the Ministry of Welfare related to spending on sick leave benefits by: implementing controls to limit the duration of sick leave (L3 million); and (ii) submitting a proposal to Parliament to reduce replacement rates for long-term sickness benefits.

- $\quad$ By end-April 2012, we will prepare a new strategy on public administration. This strategy will, inter alia, normalize the distribution of employees within the unified wage grid based on effective skills-assessment, and introduce central control over the establishment of new posts. We will also prepare proposals to reform the wage grid and make it more fair towards low-paid employees, award best performers and attract highly-skilled officials (e.g. by setting wages for higher positions closer to private sector levels), as well as prepare proposals for a scheme to reward good and excellent performance of public sector employees.

\section{We are also taking the following steps in support of spending restraint:}

- Continue to cap the daily provision allowance for employees of the Ministry of Defense, Ministry of Justice, and Ministry of Interior at the 2011 level.

- $\quad$ Continue to cap vacation allowances at 25 percent of the monthly wage in state and local governments till 2013.

- $\quad$ Freeze at 2011 levels compensation payments to landowners engaged in conservation activities till 2013.

- $\quad$ Our 2012 budget will include the following measures that take effect from 2013: 
- We will: (i) consider lowering existing thresholds for tax rates on residential property with a view to ensure a broadly equal distribution of the housing stock between the three tax brackets; (ii) abolish the 25 percent limit on annual increases in the real estate tax on land (L10 million); and (iii) carry out cadastral reform to properly reflect the depreciation and market value of residential housing.

- $\quad$ By September 2012, we will adopt a comprehensive reform of the state family benefits and social assistance system to improve targeting to the poorest families, and will review tax exemptions for children (potential saving: L10 million).

- We will reform the social safety net system to improve incentives and reduce poverty traps.

- We will: (i) continue to limit the maximum amount of maternity, paternity, parental, unemployment and sickness benefits until the end of 2014; (ii) submit to Parliament a proposal to continue to cap the replacement rate of maternity and paternity benefits at 80 percent starting from 2013 . The proposal will be submitted together with 2012 budget (L5.3 million in 2013); (iii) keep in place the ceilings on social contributions for high income earners beyond 2014. This will limit the maximum amount of social insurance that high income earners can receive.

- $\quad$ Sale of EU emission trading permits (L25 million).

12. We will submit a supplementary budget for Parliamentary approval if the measures included in the $\mathbf{2 0 1 2}$ budget are not sufficient to meet our $\mathbf{2 . 5}$ percent deficit target (ESA95).

\section{Beyond 2012, we plan to reduce the ESA deficit towards our medium-term}

objective. Given our goal of further deficit reduction, we will not increase spending or cut taxes during 2012 beyond what is envisaged in the budget. Any revenue over-performance will be used primarily to achieve a lower than targeted budget deficit; we will not increase spending beyond levels in the budget except for accelerating the absorption of the EU funds, or for covering additional needs for social safety net or for active labor market policies. A lower budget deficit will limit the amount of adjustment needed in 2013. Starting from 2013, we will comply with the SGP condition of achieving 0.5 percent of GDP improvement in the structural deficit per year as a benchmark, until we reach our medium term objective.

Reductions in social insurance allowances (unemployment, sickness, parental, and maternity and paternity benefits) will remain in force. During 2012, we will review the possibility of extending the temporary suspension of indexation of pensions. We will also develop clear remuneration guidelines to make sure that public service remains attractive for well-qualified personnel. 


\section{We are redoubling our efforts to strengthen tax administration and combat the}

grey economy. In our 2012 budget, we will restrict the frequency with which tax-free goods can be brought through the non-EU border (which should limit smuggling), apply a withholding PIT on scrap metal, and regulate the online gambling industry, to combat the grey economy. We will provide an amnesty for penalties and interest accrued on unpaid taxes (postponed activity from 2010), which should increase the incentive to pay off overdue taxes while requiring a submission of a zero declaration of income and assets. As part of our tax compliance strategy, we will provide sufficient resources and incentives to the State Revenue Service, and increase the share of audit staff and complete more audits. We will raise internal control and ensure strict implementation of standards and administrative, pecuniary and criminal fines within the public sector. While fighting the grey economy is our top priority, we recognize that their revenue yield is uncertain and hard to quantify.

\section{In parallel, we are making efforts to strengthen fiscal discipline to preserve medium-term fiscal sustainability.}

- We submitted the Fiscal Discipline Law to the Parliament on December 6, with an objective of zero general government balance in the medium term. The FDL clearly defines: (i) principles of a counter-cyclical fiscal policy; (ii) a fiscal balance rule as an instrument for a sustainable and counter-cyclical policy; (iii) a debt rule; (iv) transitional provisions, including consistency with the SGP provisions; and (v) escape clauses, moral sanctions, and monitoring and reporting requirements to ensure compliance with the fiscal rules.

- To support the FDL, we will submit to the Parliament constitutional amendments to make the law more effective. We intend the make the purpose of the constitutional amendments clear in the explanatory notes to the constitution. In addition, we have recommended amendments to the "Rules of Procedures of the Saeima" to ensure that the MoF is given adequate time to evaluate all proposals to change the tax laws before voting in the Parliament.

Within six months of the FDL's approval, we will submit a medium-term budget framework law to Parliament, so that it comes into force at the latest with the 2014 annual budget. This law will provide a multi-annual framework for our budgeting procedures and, in accordance with the FDL, will set binding expenditure ceilings for $2+1$ years on a rolling basis. It will also include a prohibition on raising spending within the year due to over-performing revenues, and limit the possibility of introducing expansionary fiscal measures after adoption of the budget. These measures are aimed at preventing a return to pro-cyclical policies and the fiscal indiscipline that contributed to the economic crisis.

- $\quad$ To ensure that we meet our future deficit targets, we will not launch any new PPPs in 2012 (except concessions when government assumes no risk or liability). We also continue to cap public guarantees at L754 million (the level in June 2009, when 
the 2009 supplementary budget was passed). If new PPPs are necessary, they should be offset by savings in other areas.

- We are taking steps to limit the impact of Krajbanka's financial difficulties. We are issuing a L200 million state loan to the Deposit Guarantee Fund, to ensure the payout of insured deposits in Krajbanka. If necessary, we will be ready to issue additional state loans to state and municipal institutions that lost financial resources in Krajbanka, to ensure the continuity of these institutions' operations.

- We will reform the governance of SOEs according to our newly developed and approved concept paper, and proceed with orderly privatization of the companies that should not belong to the public sector and sale of minority holdings in companies where public participation is not justified.

- We aim to maximize absorption of EU structural aid, while improving the efficiency of such spending. At the same time, we will keep in mind the additionality principle for the EU funds which states that these funds may not substitute national investment expenditures.

- We will not include in the 2012 state budget a clause allowing an increase in appropriations without Parliamentary approval ( 0.2 percent of GDP in 2011 budget). At the same time we will keep the budgetary fund for unforeseen events in an amount of L17 million.

\section{We have taken steps to stabilize airBaltic and will ensure that it does not create} unexpected fiscal liabilities (we estimate that in 2010 and 2011 it lost $\mathbf{L 7 7}$ million). We believe that a well-functioning and sustainable national airline contributes to Latvia's economic development. For this reason, we have taken prompt action to stabilize the company and will take further steps to shore it up in a manner consistent with best practice in public financial management:

- We have made a loan of L16 million to airBaltic and the former private shareholderBaltic Aviation Systems (BAS) - has made a loan of L14 million under a set of contractually-defined conditions. As part of this operation, the company's statutes have been rewritten, new management, board, and council members have been appointed. All creditors related to the financiers have declared that their claims on airBaltic amount to $€ 70$ million. These claims are being restructured: half will have a 10 year maturity postponed until after a five year grace period; the other half has a 10 year maturity postponed until the company is profitable for two years in succession.

- We expect to inject a further L41 million together with L37 million from the financiers, both in equity financing, if the following conditions are met: (i) the state of Latvia and the private shareholder have made the initial contribution as described above; (ii) the auditor of the company has submitted an opinion regarding the 2010 
financial statements and BAS subsidiaries have been audited (the auditor's statement was approved in the shareholders meeting on November 28, 2011); (iii) a new business plan that returns the airlines to profitability developed by a consultant of international repute has been approved by the board and council; and (iv) BAS subsidiaries have been consolidated back into airBaltic in accordance to the conditions established in the contract signed with the financiers. This will provide airBaltic with financial resources and managerial skills to reorient its business model, limit expected losses in 2012 to L24 million, and return to profitability in 2013.

We have put in place safeguards to ensure that the private shareholder delivers on its commitments and that state funds are not misused. More specifically, the state has operational control of airBaltic under the new statutes and at present

(December 1, 2011) owns 99.8 percent of the shares of airBaltic, which ensures complete control over the company.

We are taking steps to improve governance in airBaltic and prevent it from becoming a future fiscal drain. In order to resolve the situation in the least costly way, airBaltic will settle claims with its creditors and consolidate BAS subsidiaries in a manner that avoids any direct or indirect bailout of the private shareholder. Public funds will not be used to repay debts to the private shareholder or to purchase subsidiaries from the private shareholder. We will undertake a forensic audit of airBaltic and its related companies and if evidence of fraud or any other wrongdoings is found, we will take legal action against the responsible persons. For the sake of transparency, we will make the 2010 and 2011 audits and the shareholder agreement public. If necessary, we stand ready to take further measures to ensure that the state does not support an unviable or poorly managed company.

- We have taken all necessary steps to notify the European Commission about the planned joint investment with the private shareholder. The investment follows the private investor principle, with public and private shareholders investing in the company jointly and proportionally, and under the same conditions. As a result, we consider this investment to not be state aid as defined by EU state aid legislation. The first investment of L9.9 million took place on November 2.

If the financiers fail to inject the second tranche of the agreed financing of L37 million by December 16, 2011 we will: (i) initiate all legal actions foreseen in the contract with the financiers; (ii) amend the business plan in a way which ensures that no further investments are necessary and there is no impact on the state budget deficit in 2012-2013; (ii) urgently seek an alternative strategic investor for airBaltic; and (iv) take all necessary steps to notify the European Commission about possible state aid issues and consult with EC in order to assure compliance to state aid issues.

17. Pension reform will support our long-term fiscal goals. Following our concept paper on pension reform, starting in 2014 we will submit the draft law to increase the early and statutory retirement ages and the qualification period for retirement. In 2012 we will 
eliminate the 2006 supplementary pension for pre-1996 working years (extended to all pensioners in 2008) for new retirees and will review the possibility of extending the suspension of pension indexation, while protecting the poorest pensioners. We remain committed to preserving the sustainability of the three pillars of our pension system and to restoring contributions to the second pillar to 6 percent of gross salaries by 2013, provided that the budgetary situation improves in line with our forecast.

\section{Increasing labor market participation, while protecting the most vulnerable} members of society, remains our priority. Our ALMP strategy will guide us after 2011, when the Workplace with Stipend Program expires. This strategy includes training and a new public works program for those who have been unemployed for more than 6 months and who are not entitled to unemployment benefits. We plan to spend up to 0.3 percent of GDP on active labor market policies in 2012, and we will reallocate up to L23 million from the EU structural funds for regional development to the European Social Fund (ESF), and a further L14 million within the ESF towards ALMPs . Given the uncertainty surrounding the economic recovery, we intend to maintain safety net spending at 0.4 percent of GDP and to keep the current social safety net in place, co-funding GMI payments in 2012, and co-financing the housing benefit until end-April 2012. By end-March 2012, we will conduct a study to evaluate our social assistance and, in cooperation with the European Commission and the World Bank, design a scheme which encourages labor market entry while protecting the poor. The new system will be introduced from 2013. We are considering the possibility of introducing tax incentives for firms which create net new jobs, and will also continue to improve our wage subsidy schemes to encourage hiring of the long-term unemployed, while avoiding substitution effects.

\section{We have started the transition back to market financing with a successful}

Eurobond placement in June 2011. Our debt strategy will pre-finance the relatively large repayments coming due to official creditors in the coming years. Next year, we plan to issue an equivalent of U.S. dollar 1 billion in new bonds in international capital markets and we will continue to regularly issue short- and long-term domestic debt in accordance with our debt strategy, with a view toward maintaining benchmark maturities along the yield curve and reducing rollover risk. We expect a net increase in domestic borrowing of L100 million. Overall borrowing in coming years will be limited to an amount consistent with continued debt sustainability.

\section{Monetary and Exchange Rate Policies}

20. Our monetary policy strategy is to maintain the fixed (narrow band) exchange rate until we adopt the euro, and for our main refinancing rate to converge to that of the ECB. Maintaining monetary and financial stability requires credible policymaking independence. As such, we reaffirm the existing strong institutional and financial independence of the BoL and FCMC as a basis for continued stability. We will also adjust 
our policy stance if necessary to ensure monetary conditions in Latvia remain consistent with our fixed exchange rate.

\section{Our exchange of program financing in the market has worked well and will} continue in the period ahead. After selling significant amounts at the beginning of 2011, Treasury foreign exchange sales decreased to around $€ 5$ million per week between July and September due to much lower financing needs. In total, through the first week of October, we sold the equivalent of L500 million in foreign exchange. However, sales for the whole year are likely to be higher due to the usual increase in spending at the end of the year. To ensure that Treasury sales are not perceived as discretionary foreign exchange interventions, we will continue to pre-announce the amounts for sale four weeks ahead, and sales will be determined by fiscal financing needs.

\section{Financial Sector}

22. We will continue our close supervision of the financial sector and to strengthen banking regulations in line with $\mathrm{EU}$ directives:

- $\quad$ Certain capital requirements related to securitized positions that carry higher risk have been increased. We will also update our legislation to fill the remaining gaps with the European Systemic Risk Board's recommendations on FX lending.

- We are preparing to implement the EU's forthcoming Capital Requirements Regulation (CRR I) which will improve capital quality, ensure sufficient liquidity, and limit banks' leverage. The EU Capital Requirements Directive (CRD IV) expected to be approved in mid-2012) will be transposed into national legislation to introduce a capital conservation buffer of 2.5 percent of total risk weighted assets in addition to the 8 percent capital requirement set in the CRR. Latvian authorities will be authorized to introduce a countercyclical capital buffer of up to 2.5 percent or higher on top of the minimum capital requirement if there is a need to prevent excessive credit growth. Both capital buffer requirements shall be met by Common Equity Tier 1 capital.

- We will: (i) continue our tight supervision of the financial system, and reiterate our commitment to strengthen banks' capital base, including by waiving the transitional period for capital requirements foreseen in CRR I; (ii) continue to make the utmost use of our supervisory powers under the second pillar of CRD and impose higher capital requirements for banks whose business model is oriented to servicing nonresidents that entails additional risks; (iii) draft amendments to the Criminal Law to strengthen responsibility for submission of deliberately distorted or incomplete information to the supervisory authority; (iv) strengthen the FCMC's capacity to conduct forensic investigations, and broaden the mandate of the FCMC's Financial Integrity Division to conduct forensic investigations of financial institutions and ensure their involvement in fit and proper assessments of banks and in issues related 
to the prevention of money laundering; and (v) mandate external auditors to perform a reconciliation of correspondent and securities account balances of all banks by December 21, 2012. This audit will include information on the encumbrance of these assets, and an assessment of the necessity to make additional provisions.

- We have increased the emphasis on consumer rights in the financial sector. Following recent amendments to the Law on Credit Institutions, banks have an obligation to review and respond to consumer complaints within 30 days. We have also issued guidelines aimed at improving communication between market participants and their existing and potential customers. A range of measures has also been taken-including a dedicate website called "Customer School" to educate consumers about the most popular financial products and services available in Latvia and their inherent risks.

\section{We submitted our sales strategy for MLB to the EC on November 2, 2011, and have started the process of selling its commercial part:}

- $\quad$ Together with our sales consultant, we have submitted our sales strategy, consistent with the transformation plan submitted to the EC in April. Bundles of commercial assets and liabilities (including all deposit accounts with the exception of a small amount of current accounts related to the disbursement or repayment of development loans) will be sold in a two-stage auction. Originally due by end-June, the sales strategy was delayed due to late hiring of the sales consultant, the unanticipated parliamentary elections, and difficulties in forging a political consensus.

- We have publicly announced our plan to sell the commercial part of the bank. We have already received initial bids that we are currently reviewing, and will sign final sales agreements by end-March 2012 .

While we are committed to sell all assets of the commercial part, we may decide not to sell some commercial assets if we consider bids to be below the value we can obtain by recovering them ourselves. Such assets will be carved out of the remaining development bank and placed in the Latvian Privatization Agency for a more gradual workout (managed by Parex), but only if we are sure this will maximize value to the state.

- In case the assets that accompany the deposits in bundles 1 and 2 are not sold, we will implement a contingency plan (including effective communication strategy) for the orderly divestiture of deposits to limit risks to financial stability.

- $\quad$ After divesting the commercial assets, we intend to merge the development part of MLB with other state institutions to create one development institution (see $\$ 24)$

- $\quad$ Once the commercial parts of MLB have been sold or transferred to the Latvian Privatization Agency, the bank will not be allowed to attract any new private deposits (except for current accounts directly related to the disbursement or repayment of development loans). The FCMC will ensure compliance with this commitment. 
24. We will approve an action plan for the creation of a single development lending institution by mid-2012, with a view to implement it by end-2012. The development institution will be subject to strict regulation and supervision in line with applicable legislation. This will optimize development lending in Latvia and ensure more effective use of EU funds, including on-lending of concessional funds using commercial banks as intermediaries. The new institution will not be permitted to attract deposits or to lend directly to clients, except for already approved concessional programs (we estimate this at L230 million), or where the lending is: (i) associated with products not offered by the commercial banks or non-bank financial institutions; (ii) dependent on highly specialized knowledge that commercial banks or non-bank financial institutions do not possess: or (iii) of too small volume or too risky to be of interest to commercial banks or non-bank financial institutions. MLB will not start any new direct loan programs until the action plan for the new development institution is approved. We intend to work closely with the $\mathrm{EC}$ on implementation of this plan, as set out in the EC SMoU.

\section{We expect to complete the sale of Citadele Bank by end-March 2012.}

- We have started the sale of Citadele Bank and received initial bids for the bank in end-October. Bidder due diligence is currently taking place; we expect to present final bids to the Cabinet of Ministers in mid-January 2012. Sale of the bank should take place by end-March.

- We remain committed to ensuring that none of the former shareholders that were party to the Investment Agreement at the time of the initial government intervention in Parex, or any investors associated with these shareholders, are allowed to participate in any aspect of the Citadele Bank sale. Any potential purchaser of Citadele Bank's assets must be approved by the FCMC and the EC.

- Until the bank is sold, we will make sure that it meets all regulatory requirements (including liquidity) and remains compliant with the EC-restructuring plan.

26. We will continue the orderly resolution of Parex Bank by removing the banking license and converting it to a special purpose joint stock company (SPV), in order to maximize returns to the state.

- $\quad$ As an SPV, Parex would not need to meet regulatory requirements such as holding minimum capital, provisioning according to banking regulations, or contributing to the deposit insurance fund, effectively decreasing operating costs. The SPV's management will be directed to conclude the resolution as soon as possible, with specific dates embedded in the SPV's goals. Management remuneration should align incentives with those of the state, namely to maximize recoveries. When making this transformation, we will aim to minimize the risk of legal challenges to the split of the Parex bank into Citadele and Parex. We expect to accomplish this modification by end-February 2012. 
- We will make sure that Parex (and the future SPV) continues to dispose of assets in a way that maximizes recoveries and avoids fire-sales. Funds from asset sales will be distributed periodically to State Treasury, to limit Parex's cash resources to its operational needs.

- We will keep Citadele and Parex as two separate entities to maximize the chances of selling Citadele to private investors.

27. We are pursuing Parex's former shareholders and senior managers for losses they caused to Parex bank and to the state. A number of civil and criminal court casesincluding a claim by Parex Bank for L62 million in losses, and by the Latvian Privatization Agency for breach of the investment agreement - against the former majority shareholders of Parex are underway. We intend to continue to explore all legal avenues for seeking compensation in court from the two former majority shareholders and senior managers for losses caused to the state and to the bank.

28. We have taken prompt actions to safeguard interests of Krajbanka's clients. To limit the potential negative impact of developments in Bank Snoras, Krajbanka's parent bank, we initially limited withdrawals to L100,000 per customer per month. Shortly afterwards we suspended the bank's activities because of the discovery of a deficiency of assets in the bank and also a deficiency of own funds due to fraudulent activities.

Management of Krajbanka was taken over by FCMC appointed authorized representatives, while a criminal investigation into the actions of Krajbanka's management was launched. To alleviate the burden on the most severely affected customers, including pensioners, withdrawals of up to L50 per day were allowed on 24-26 November. Reimbursement of insured depositors started on November 29 using the bank's liquid assets and resources from the Deposit Guarantee Fund. The guaranteed amount will fully cover the claims of 99.8 percent of Krajbanka's customers. We are initiating insolvency procedures for Krajbanka.

29. We have withdrawn the proposal to grant priority status in foreclosure proceedings to utility companies' unsecured claims, but remain committed to address the issue of unpaid utility bills. To that end, we have submitted legislation requiring utility companies to provide written warnings to debtors in arrears for more than 3 months, and to initiate court proceedings if debts remain unpaid for a further 20 days, in order to prevent these debts from becoming unmanageable. Recently introduced procedures for small claims (up to L1500) will make it cheaper and faster for utility companies to recover their debts. We are also reviewing the system of court and bailiff fees to reduce the cost of enforcing claims, and intend to establish a new (privately operated) credit scoring registry (subject to data protection laws) for service providers (including utility companies) not covered by the existing credit registry, in order to improve debtor discipline. Further, we will assess the extent to which the true problem of unpaid utility bills is that of poverty and inability to pay, and will develop safeguards to protect the poor. 


\section{OTHER ISSUES}

30. We will continue to place all long-term program funds in special sub-accounts at the Treasury's euro account at the BoL. Should these program accounts intended for budget support fall by more than EUR 250 million in any 30-day period, the Ministry of Finance will consult with EC and IMF staff. In anticipation of large cash buffers arising from pre-funding of repayments to official creditors, the Treasury will develop a cash management strategy in consultation with the Bank of Latvia and IMF staff.

\section{The Latvian government will work closely with the $\mathrm{EC}$ to pursue reforms as} specified in our SMoU with the EC, in particular to improve the business environment and to make more efficient use of EU-cofinanced financial instruments and R\&D support programs.

32. The Cabinet of Ministers will take all necessary steps to ensure implementation of the commitments outlined in this Letter. However, commitments which the Constitution stipulates are under the purview of Parliament will remain subject to the legislation process and final approval by the Saeima.

\section{IMF ARRANGEMENT}

33. On top of our previous commitments under the program, we believe the policies described above are sufficient to achieve the goals of our economic program.

Nevertheless, we stand ready to take additional measures needed to keep the program on track. We will consult with the EC, IMF, and other program partners on the adoption of these measures and in advance of any revisions to the policies contained in this Letter in accordance with the IMF's policies on such consultation. In addition, we will supply information the IMF requests on policy implementation and achievement of program objectives in a timely manner.

Sincerely yours,

$$
\begin{gathered}
/ \mathrm{s} / \\
\text { Valdis Dombrovskis } \\
\text { Prime Minister }
\end{gathered}
$$

$/ \mathrm{s} /$

Andris Vilks

Minister of Finance
$/ \mathrm{s} /$

Ilmārs Rimšēvičs

Governor of the

Bank of Latvia

For the

responsibilities

of the BOL

$/ \mathrm{s} /$

Jānis Brazovskis

Acting Chairman

Financial and Capital Market Commission 
Table 1: Latvia: Quantitative Performance Criteria and Indicative Targets under the Stand-By Arrangement, Fifth Review (In millions of lats unless otherwise indicated)

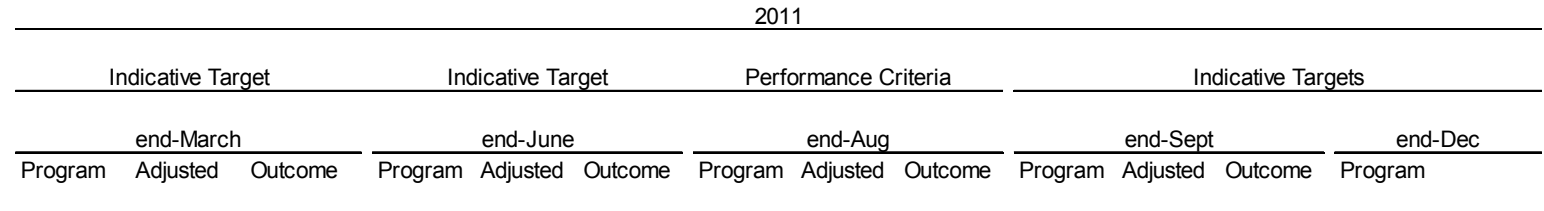

\section{Quantitative performance criteria}

Floor on net international reserves of the Bank of Latvia (millions of euros) $1 /$

Ceiling on net domestic assets of the Bank of Latvia 1/

$-114 \quad 788$

788

$222 \quad 609 \quad 918$

76

$463 \quad 1,110$

$3 \quad 390 \quad 1,116$

$-580$

1,960

1,843

1,184

Floor on primary non-EU cash fiscal balance 2/3/

$-35 \quad-52$

$39 \quad-33$

$125 \quad-23$

$161 \quad-69$

Ceiling on public guarantees

\section{Continuous performance criteria}

Ceiling on accumulation of general government domestic arrears

Ceiling on accumulation of general government external arrears (millions of euros)

\section{Staff consultation clauses}

If international reserves fall by more than $€ 500$ million in any given

30-day period

If sub-accounts for program budget support fall by more than

$€ 250$ million in any 30 -day period

\section{Indicative target}

Ceiling on the general government wage bill $2 /$

197

186

505

440

635

570

700

635

929

1/ NIR targets will be adjusted downwards/upwards and NDA targets will be adjusted upwards/downwards by the net change in emergency liquidity assistance (TMU ॠ6). NIR targets will be adjusted upwards (and NDA targets adjusted downwards) for any nonconcessional external debt issued by the government (TMU q7).

2/ Cumulative from the beginning of the fiscal year.

3/ Adjusted downwards for additional social safety net spending (TMU ๆ13), and adjusted upwards for excess EU funds-related spending (TMU ף14) and excess net

lending (TMU $\mid 16)$. 
Table 2: Latvia: Quarterly Projections, Fifth Review under the Stand-by Arrangement

\begin{tabular}{|c|c|c|c|c|}
\hline & \multicolumn{4}{|c|}{2012} \\
\hline & end-March & end-June & end-Sep & end-Dec \\
\hline Real GDP (growth rate, year-on-year) & 3.5 & 2.0 & 2.1 & 2.5 \\
\hline Inflation (growth rate, year of year) & 3.2 & 1.9 & 2.0 & 2.3 \\
\hline Gross international reserves of the Bank of Latvia (billions of euro) & 5.3 & 5.2 & 5.7 & 5.3 \\
\hline Primary non-EU cash fiscal balance (millions of lats) $1 / 2 /$ & 91 & 183 & 372 & 365 \\
\hline Total revenue and grants (millions of lats) $1 /$ & 1375 & 2829 & 4137 & 5450 \\
\hline Total expenditures (millions of lats) $1 / 2 /$ & 1340 & 2727 & 3901 & 5561 \\
\hline
\end{tabular}

Source: IMF staff calculations agreed with the Bank of Latvia and the Latvian Ministry of Finance.

$1 /$ Cumulative from the beginning of the fiscal year.

2/ Excludes net lending. 
Table 3. Latvia: Structural Benchmarks

\begin{tabular}{l} 
Structural Benchmark \\
\hline Fiscal Policy: \\
Prepare a menu of options to achieve \\
the 2012 deficit target.
\end{tabular}

Prepare a menu of option
the 2012 deficit target.

Fiscal sustainability: A menu of options developed early in the budget cycle will facilitate preparation of the 2012 budget based on highquality measures.

Revise the tax compliance strategy, taking into account recommendations of an upcoming technical assistance mission from the IMF.

Submission of a 2012 budget to Parliament consistent with the goal of convincingly meeting the Maastricht deficit criterion.

Complete a strategy to improve management of state-owned enterprises.

Submission to Parliament of a draft Fiscal Responsibility Law in consultation with the IMF and the EC

Prepare an active labour market policy (ALMP) strategy that will replace the WWS program.

\section{Financial Sector:}

Hire a qualified, experienced, and independent sales consultant mobilizing a team of internationally reputable experts to prepare and run the MLB sales strategy.

Submit a MLB sales strategy to the EC and appoint a qualified and independent head of restructuring with international experience to oversee the restructuring and sales process.

Submit amendments to the initial proposal to amend the Civil Procedure Law to Parliament.
Fiscal sustainability: Improved tax compliance will increase revenue and facilitate the achievement of fiscal deficit objectives. Governance: reduce the gray economy.

Fiscal sustainability: A strong 2012 budget will be needed to convincingly meet the Maastricht deficit criterion and move Latvia toward the goal of euro adoption in 2014.

Fiscal sustainability: Improve fiscal transparency, reduce fiscal risks, and potentially raise government revenues.Growth: Increase economic efficiency by reducing state involvement in areas that could be served by the private sector.

Fiscal sustainability: This will help anchor fiscal policy on a credible path following completion of the program, ensure the sustainability of public debt, and allow for counter-cyclical fiscal policy.

Fiscal sustainability: The new policy will allow a transition away from emergency social safety net spending towards more traditional ALMP spending.

Financial stability: Stem further erosion in the bank's value and maintain depositor confidence. Fiscal sustainability: Limit the need for continued public recapitalization.

Financial stability: Stem further erosion in the bank's value and maintain depositor confidence. Fiscal sustainability: Limit the need for continued public recapitalization.

Financial stability: The amendments will address a number of concerns with the initial proposal to address unpaid debts to utility companies, including its retroactive character.
Financial stability: Stem further erosion in the bank's value and maintain depositor confidence. Fiscal sustainability: Limit the need for continued public recapitalization.
Mid-August

Partially done with delay. The menu of options was delayed by parliamentary elections. It was communicated verbally to staff during the October mission.

End-August

Done with delay. The authorities are revising their tax compliance strategy in light of $F A D$ recommendations. It should be completed by mid-December.

End-September

Done with delay due to the parliamentary elections. The budget is expected to be submitted to Parliament on December 7.

End-October Completed

End-November

Done with delay. The Fiscal Responsibility Law was approved by the Cabinet on November 29, and will shortly be submitted to Parliament.

End-November Completed.

End-May

Done with delay. The authorities hired Blackstone and SEB Enskilda in June to assist in the sale of the commercial part of MLB.

End-June

Done with delay due to the delay in hiring the sales consultant, the parliamentary elections, and difficulties in forging a political consensus. The sales strategy was submitted to the EC on November 2.

End-July

Done with delay. The initial proposal to amend the Civil Procedure Law has been withdrawn and replaced with legislation that requires utility companies to take prompt action to collect unpaid bills.

Delayed due to a late completion of the sales strategy. Authorities are soliciting bids for the commercial assets, and plan to sell the bank by end-March 2012. 


\title{
INTERNATIONAL MONETARY FUND
}

\author{
REPUBLIC OF LATVIA
}

Fifth Review Under the Stand-By Arrangement and Financing Assurances Review, Request for Waiver of Nonobservance of a Performance Criterion, and Proposal for Post-Program Monitoring-Informational Annex

Prepared by the European Department (In Consultation with Other Departments)

Approved by Anne-Marie Gulde-Wolf and Claire Waysand

December 5, 2011

Contents

Appendix

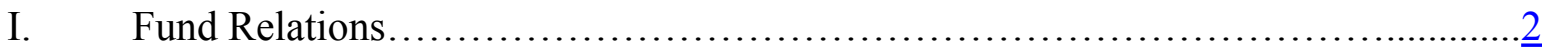

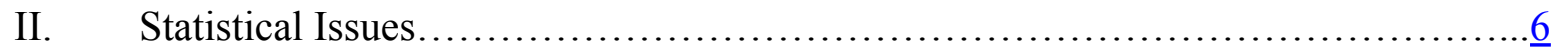

II. World Bank Relations......................................................... 


\section{APPEndix I. LATVia: Fund Relations}

(As of October 31, 2011)

I. Membership Status: Joined May 19, 1992; Article VIII.

II. General Resources Account:

Quota

Fund holdings of currency

Reserve position in Fund

III. SDR Department:

Net cumulative allocation

Holdings

IV. Outstanding Purchases and Loans:

Standby Arrangement
SDR Million

142.10

$1,124.30$

0.06

SDR Million

120.82

100.77

SDR Million

982.24
Percent of Quota

100.00

791.20

0.04

\section{Percent of Allocation}

100.00

83.41

Percent of Quota

691.23

V. Latest Financial Arrangements:

Type

Approval Date

Expiration Date

$12 / 23 / 08$

$04 / 20 / 01$

$12 / 10 / 99$

$10 / 10 / 97$
$12 / 22 / 11$

$12 / 19 / 02$

$4 / 9 / 01$

$4 / 9 / 99$
Amount

Approved

(SDR million)

$1,521.63$

33.0

33.0

33.0
Amount Drawn

(SDR million)

982.24

0.00

0.00

0.00

VI. Projected Obligations to the Fund:

$\begin{array}{lccccc} & \underline{2011} & \underline{2012} & \underline{2013} & \underline{2014} & \underline{2015} \\ \text { Principal } & 0.0 & 290.0 & 435.1 & 201.1 & 56.1 \\ \text { Charges/interest } & 6.53 & 23.2 & 12.6 & 2.7 & 0.4 \\ \text { Total } & 6.53 & 313.2 & 447.7 & 203.9 & 56.5\end{array}$

\section{Exchange Arrangements:}

The currency of Latvia is the lats, which was introduced in March 1993 to replace the Latvian ruble. The exchange rate was pegged to the SDR from February 1994 to December 2004, within a \pm 1 percent band. On January 1, 2005, the lats was repegged to the euro at the rate $€ 1=0.702804$ lats, and on April 29, 2005, Latvia entered ERM II, maintaining the previous band width. On April 28, 2011 the lats was equal to U.S. dollar 2.09. Latvia maintains an exchange restriction arising from the imposition by the government of a partial deposit freeze on Parex Bank subject to Fund approval under Article VIII, Section 2(a), which the Executive Board approved on July 7, 2011 until December 31, 2011 or the 
conclusion of the next Article IV consultation with the Republic of Latvia, whichever is earlier. Exchange restrictions maintained for security reasons have been notified to the Fund for approval most recently in March 2011 (see EBD/11/11 March 11, 2011).

\section{Article IV Consultation:}

Latvia is on the 24-month consultation cycle.

The 2010 Article IV staff report was issued on December 9, 2010 (Country

Report No. 10/356). The last Article IV Board discussion took place on July 21, 2010.

The Public Information Notice No. 10/104 was released on August 12, 2010.

\section{Safeguards Assessment:}

The safeguards assessment completed on July 8, 2009 concluded that the Bank of Latvia (BoL) operates robust internal audit and control systems. The assessment recommended clarifying the BoL and Treasury's respective roles in holding, managing, and reporting to the Fund audited international reserves data. It also recommended amendments to the mandate of the BoL's audit committee and improvements to the financial statements' disclosures. The authorities have already taken steps to implement these recommendations, notably by establishing a formal arrangement between the BoL and Treasury, revising the audit committee charter and expanding the existing accounting framework.

\section{FSAP Participation and ROSCs:}

A joint World Bank-International Monetary Fund mission conducted an assessment of Latvia's financial sector as part of the Financial Sector Assessment Program (FSAP) during February 14-28, 2001. The Financial Sector Stability Assessment (FSSA) report was discussed at the Board on January 18, 2002, together with the 2001 Article IV staff report (Country Report No. 02/10). An AML/CFT assessment mission took place during March 8-24, 2006, and the report was sent to the Board on May 23, 2007. A joint IMF-World Bank mission conducted an FSAP Update during February 27-March 9, 2007. A World Bank mission conducted an FSAP development module during November 8-18, 2011.

\section{ROSC Modules}

Standard/Code assessed

Code of Good Practices on Fiscal Transparency

Issue date

Code of Good Practices on Transparency in Monetary and Financial Policies March 29, 2001

Basel Core Principles for Effective Banking Supervision

CPSS Core Principles for Systemically Important Payment Systems

IOSCO Objectives and Principles of Securities Regulation

IAIS Core Principles

OECD Corporate Governance Principles

Data Module

January 2, 2002

January 2, 2002

January 2, 2002

January 2, 2002

January 2, 2002

January 2, 2002

June 23, 2004 


\section{Technical Assistance (2007-11):}

Dept.

Project

FAD Expenditure Policy

FAD Tax Policy

FAD Revenue Administration

MCM Bank Resolution

FAD Public Financial Management

$\mathrm{MCM} /$

LEG

LEG

Debt Restructuring

MCM

FAD

FAD Revenue Administration

FAD Public Financial Management

FAD Cash Management

MCM Mortgage and Land Bank

$\mathrm{MCM}$

Deposit Insurance

MCM Liquidity Management

LEG Bank Resolution Legal Framework

FAD Tax Policy

LEG Bank Resolution Legal Framework

LEG Corporate and Personal Insolvency Law

FAD Public Financial Management

LEG Corporate and Personal Mission Insolvency Law

MCM Stress Testing

FAD Expenditure Policy

FAD Revenue Administration

LEG Legal Framework for Foreclosure Procedures

FAD Public Financial Management

FAX Tax Administration
Action

Mission

Mission

Mission

Mission

Mission

Mission

Mission

Mission

Mission

Mission

Resident Advisor

Mission

Mission

Mission

Mission

Mission

Mission

Mission

Mission

Mission

Mission

Mission

Mission

Missions

Mission

Mission
Timing

June 2007

March 2008

January 2009

January 2009

March 2009

March 2009

Feb-March 2009

March 2009

April-May 2009

July 2009

July 2009-June

2010

July-August 2009

September 2009

September 2009

November 2009

January 2010

February 2010

February 2010

March 2010

April 2010

April 2010

June 2010

August 2010

September 2010

November 2010

Feb-March 2011

June 2011

\section{Counterpart}

Ministry of Finance

Ministry of Finance

Ministry of Finance

FCMC, Bank of Latvia

Ministry of Finance

Ministry of Finance, FCMC

FCMC

FCMC

Ministry of Finance

Ministry of Finance

Ministry of Finance

Ministry of Finance

Ministry of Finance

FCMC

Bank of Latvia

FCMC

Ministry of Finance

FCMC

Ministry of Justice

Ministry of Finance

Ministry of Justice

Bank of Latvia

Ministry of Finance

Ministry of Finance

Ministry of Justice

Ministry of Finance

Ministry of Finance 


\section{Resident Representative:}

Mr. David Moore was appointed Resident Representative effective from June 11, 2009.

2010 Proposed Board amendment:

Latvia has not yet accepted the 2010 Proposed Amendment for an all elected Board and consented to its quota increase under the $14^{\text {th }}$ General Review. 


\section{APPENDIX II. LATVIA: STATISTICAL ISSUES}

\section{LATVIA-STATISTICAL ISSUES APPENDIX \\ As of November 15, 2011 \\ I. Assessment of Data Adequacy for Surveillance}

General: Data provision to the Fund is adequate for surveillance purposes. The shortcomings for each statistical area are presented below.

National Accounts: The CSB compiles and publishes quarterly national accounts using the production and expenditure approaches on a regular and timely basis. Since September 2011, national accounts are calculated using the NACE rev. 2 classification, determined by the European Commission. However, there are significant discrepancies between the GDP estimates based on production and those based on expenditure. The statistical discrepancy is included in the estimate of changes in inventories on the expenditure side, and appears to have been growing in recent periods.

The underlying data for the production approach are obtained primarily through a comprehensive survey of businesses and individuals, and are supplemented by data from labor force surveys and administrative sources. The CSB believes that the basic data understate economic activity, particularly in the private sector, and there is an ongoing effort to increase coverage. Meanwhile, official national accounts include an adjustment for under-recording. Additional data for the expenditure-based accounts are obtained from household budget surveys and other surveys from the State Treasury and ministries.

Government finance statistics: Fund staff are provided with monthly information on revenues, expenditures, and financing of the central and local governments and special budgets. With some limitations, the available information permits the compilation of consolidated accounts of the general government. The 2010 Government Finance Statistics Yearbook contains cash data in the GFSM 2001 format up to 2009. Quarterly general government data on an accrual basis are provided through Eurostat for International Financial Statistics on a timely basis.

Monetary statistics: Monetary statistics should provide for greater detail in the classification of the liabilities of depository corporations by subsectors of the general government in line with international standards.

Balance of payments: The BoL assumed responsibility for compiling the balance of payments statistics from the CSB in early 2000. The data collection program is a mixed system, with surveys supplemented by monthly information from the international transactions reporting system (ITRS), and administrative sources. Contrary to international standards - but similar to a number of other EU countries - the BoL includes provisions for expected losses of foreign-owned banks. Between Q4 2008 - Q2 2010, this treatment led to the recording of negative reinvested earnings (i.e., losses) of foreign-owned banks as negative outflows. These "inflows" in the income account of the balance of payments thus gave a positive contribution to the current account.

\section{Data Standards and Quality}

Participant in the IMF's Special Data

Data ROSC published in June 2004

Dissemination Standard since November 1, 1996.

\section{Reporting to STA (Optional)}

The authorities are reporting data for the Fund's International Financial Statistics, Government Finance Statistics Yearbook, the Direction of Trade Statistics, and the Balance of Payments Statistics Yearbook. 
LATVIA: TABLE OF COMMON INDICATORS REQUIRED FOR SURVEILLANCE

(AS OF NOVEMBER 15, 2011)

\begin{tabular}{|c|c|c|c|c|c|c|c|}
\hline & \multirow{2}{*}{$\begin{array}{c}\text { Date of latest } \\
\text { observation }\end{array}$} & \multirow{2}{*}{$\begin{array}{l}\text { Date } \\
\text { received }\end{array}$} & \multirow{2}{*}{$\begin{array}{l}\text { Frequency of } \\
\text { Data }^{7}\end{array}$} & \multirow{2}{*}{$\begin{array}{l}\text { Frequency of } \\
\text { Reporting }\end{array}$} & \multirow{2}{*}{$\begin{array}{l}\text { Frequency of } \\
\text { publication }^{7}\end{array}$} & \multicolumn{2}{|c|}{ Memo Items: } \\
\hline & & & & & & $\begin{array}{c}\text { Data Quality - Methodological } \\
\text { soundness }^{8}\end{array}$ & $\begin{array}{l}\text { Data Quality - Accuracy and } \\
\text { reliability }\end{array}$ \\
\hline Exchange Rates & $11 / 15 / 2011$ & $11 / 15 / 2011$ & D & D & D & & \\
\hline $\begin{array}{l}\text { International Reserve Assets and Reserve Liabilities of the } \\
\text { Monetary Authorities }{ }^{1}\end{array}$ & $11 / 14 / 2011$ & $11 / 15 / 2011$ & $\mathrm{D}$ & $\mathrm{D}$ & $\mathrm{D}$ & & \\
\hline Reserve/Base Money & $10 / 31 / 2011$ & $11 / 14 / 2011$ & M & M & M & \multirow[t]{4}{*}{$\mathrm{O}, \mathrm{O}, \mathrm{LO}, \mathrm{O}$} & \multirow[t]{4}{*}{$\mathrm{O}, \mathrm{O}, \mathrm{O}, \mathrm{O}, \mathrm{O}$} \\
\hline Broad Money & $10 / 31 / 2011$ & $11 / 14 / 2011$ & $\mathrm{M}$ & M & M & & \\
\hline Central Bank Balance Sheet & $11 / 14 / 2011$ & $11 / 15 / 2011$ & $\mathrm{D}$ & $\mathrm{D}$ & $\mathrm{D}$ & & \\
\hline Consolidated Balance Sheet of the Banking System & $10 / 31 / 2011$ & $11 / 15 / 2011$ & M & M & M & & \\
\hline Interest Rates ${ }^{2}$ & $10 / 31 / 2011$ & $11 / 15 / 2011$ & M & M & M & & \\
\hline Consumer Price Index & $10 / 31 / 2011$ & $11 / 8 / 2011$ & $\mathrm{M}$ & $\mathrm{M}$ & $\mathrm{M}$ & $\mathrm{O}, \mathrm{LO}, \mathrm{O}, \mathrm{O}$ & $\mathrm{O}, \mathrm{O}, \mathrm{O}, \mathrm{O}, \mathrm{O}$ \\
\hline $\begin{array}{l}\text { Revenue, Expenditure, Balance and Composition of } \\
\text { Financing }^{3} \text { - General Government }{ }^{4}\end{array}$ & $9 / 30 / 2011$ & 10/22/2011 & M & M & M & \multirow[t]{2}{*}{$\mathrm{O}, \mathrm{O}, \mathrm{O}, \mathrm{O}$} & \multirow[t]{2}{*}{$\mathrm{O}, \mathrm{O}, \mathrm{O}, \mathrm{O}, \mathrm{O}$} \\
\hline $\begin{array}{l}\text { Revenue, Expenditure, Balance and Composition of } \\
\text { Financing }{ }^{3} \text { - Central Government }\end{array}$ & $9 / 30 / 2011$ & $10 / 22 / 2011$ & M & $\mathrm{M}$ & $\mathrm{M}$ & & \\
\hline $\begin{array}{l}\text { Stocks of Central Government and Central Government- } \\
\text { Guaranteed Debt }{ }^{5}\end{array}$ & $9 / 30 / 2011$ & $10 / 18 / 2011$ & $\mathrm{M}$ & $\mathrm{M}$ & $\mathrm{M}$ & & \\
\hline External Current Account Balance & 9/30/2011 & $11 / 11 / 2011$ & M & M & M & \multirow[t]{2}{*}{$\mathrm{O}, \mathrm{O}, \mathrm{O}, \mathrm{O}$} & \multirow[t]{2}{*}{$\mathrm{O}, \mathrm{O}, \mathrm{O}, \mathrm{O}, \mathrm{O}$} \\
\hline Exports and Imports of Goods and Services & 9/30/2011 & $11 / 15 / 2011$ & M & M & M & & \\
\hline GDP/GNP & Q2 2010 & 9/8/2011 & Q & Q & Q & $\mathrm{O}, \mathrm{O}, \mathrm{O}, \mathrm{O}$ & O, LO, LO, LO, LO \\
\hline Gross External Debt & Q2 2010 & 9/2/2011 & Q & Q & Q & & \\
\hline International Investment Position ${ }^{6}$ & Q2 2010 & $9 / 2 / 2011$ & Q & Q & Q & & \\
\hline
\end{tabular}

${ }^{1}$ Any reserve assets that are pledged of otherwise encumbered should be specified separately. Also, data should comprise short-term liabilities linked to a foreign currency but settled by other means as well as the notional values of financial derivatives to pay and to receive foreign currency, including those linked to a foreign currency but settled by other means

Both market-based and officially-determined, including deposit and lending rates, discount rates, money market rates, rates on treasury bills, notes and bonds.

${ }^{3}$ Foreign, domestic bank, and domestic nonbank financing.

The general government consists of the central government (budgetary funds, extra budgetary funds, and social security funds) and state and local governments.

Including currency and maturity composition.

${ }^{6}$ Includes external gross financial asset and liability position vis-à-vis nonresidents.

Daily (D), Weekly (W), Monthly (M), Quarterly (Q), Annually (A); Not Available (NA).

${ }^{8}$ Reflects the assessment provided in the data ROSC published in July 2004, the findings of the mission that took place during September 2003 for the dataset corresponding to the variable in each row. The assessment indicates whether international standards concerning concepts and definitions, scope, classification/sectorization, and basis for recording are fully observed (O), largely observed (LO), largely not observed (LNO), or not observed (NO).

${ }^{9}$ Same as footnote 8 , except referring to international standards concerning source data, statistical techniques, assessment and validation of source data, assessment and validation of intermediate data and statistical

outputs, and revision studies. 
APPENDIX III. LATVIA: WORLD BANK RELATIONS

(As of November 15, 2011)

\begin{tabular}{|c|c|c|c|}
\hline Title & Products & $\begin{array}{c}\text { Provisional Timing of } \\
\text { Missions }\end{array}$ & $\begin{array}{l}\text { Expected Delivery } \\
\text { Date }\end{array}$ \\
\hline \multirow[t]{3}{*}{ 1. $\mathbf{B a}$} & $\begin{array}{l}\text { Public Expenditure } \\
\text { Review }\end{array}$ & May 2010 & $\begin{array}{l}\text { September } 2010 \text { (Final } \\
\text { Version) }\end{array}$ \\
\hline & $\begin{array}{l}\text { Second Special } \\
\text { Development Policy Loan } \\
\text { for Safety Net and Social } \\
\text { Sector Reform Program }\end{array}$ & April 2011 & May 2011 \\
\hline & $\begin{array}{l}\text { FSAP Development } \\
\text { Module }\end{array}$ & $4^{\mathrm{uI}}$ Quarter 2011 & $4^{\mathrm{uI}}$ Quarter 2011 \\
\hline 2. $\underset{\text { Wund }}{\text { Work }}$ & $\begin{array}{l}\text { TA on revenue } \\
\text { administration }\end{array}$ & May 2011 & July 2011 \\
\hline & Staff Visit & October 2011 & October 2011 \\
\hline & $5^{\text {th }}$ Review & November 2011 & December 2011 \\
\hline
\end{tabular}




\section{IMF Executive Board Concludes Fifth and Final Review Under Stand-By Arrangement with Latvia}

The Executive Board of the International Monetary Fund (IMF) today completed the fifth review of Latvia's performance under an economic program supported by a Stand-By Arrangement (SBA). The Board also completed the financing assurances review under the SBA. The Board decision makes available an amount equivalent to SDR 539.38 million (about $€ 637.6$ million), but the authorities do not intend to draw this amount. The total amount disbursed under the SBA remains SDR 982.24 million (about $€ 1.161$ billion). In completing this review, the Executive Board granted a waiver for nonobservances of the continuous performance criterion on imposing restrictions on the making of payments and transfers for current international transactions

This is the final review under the Fund-supported program, which was part of a coordinated effort with the European Union, Nordic governments, the World Bank, and other bilateral creditors to assist Latvia when it was hit by the global financial crisis in 2008 (see Press Release No. 08/345). With international financial support and strong ownership of the reform program, the Latvian authorities implemented difficult measures that have pulled the country out of the crisis.

The economy is now recovering and growing strongly, with economic growth of 4.5-5 percent expected in 2011, following an output decline of more than 20 percent between 2008 and 2010. Competitiveness has improved, and the very large pre-crisis current account deficits have been corrected. The authorities maintained their long-standing peg to the euro and continue to pursue their goal of adopting the single currency in 2014. A very large fiscal consolidation effort through the program period-around 15 percentage points of GDP, the bulk implemented in 2009_has corrected a large structural fiscal deficit, and given Latvia strong prospects of meeting the Maastricht fiscal deficit criterion in 2012. The authorities have also taken a series of measures to stabilize the financial sector, but further steps to improve financial sector supervision are still needed.

Despite the welcome return to economic growth, many challenges remain. Output remains well below its pre-crisis level and Latvia's unemployment rate, while decreasing, is still high at 14.6 percent. Poverty rates remain among the highest in the European Union, making the social safety net critical. 
The Latvian government's economic policy program for 2012 aims at sustaining the economic recovery in an increasingly difficult external environment, enhancing the country's ability to borrow on capital markets at affordable interest rates, and bringing Latvia closer to meeting the conditions for euro adoption, in line with its target date of January 2014.

The SBA, which was approved on December 23, 2008 for an amount equivalent to SDR 1.52 billion (about $€ 1.71$ billion), entailed exceptional access to IMF resources, amounting to 1,071 percent of Latvia's quota in the IMF (reflecting Latvia's quota increase in March 2011).

Latvia and the IMF will continue to maintain a constructive policy dialogue and, in accordance with Fund policy, initiate Post-Program Monitoring (PPM). Under PPM, members undertake more frequent formal consultation with the Fund than is the case under surveillance, with a particular focus on macroeconomic and structural policies.

Following the Board discussion, Mr. David Lipton, First Deputy Managing Director and Acting Chair, said:

"Latvia's strong performance under the Fund-supported program has helped overcome the crisis, facilitated a return to market financing, and contributed to economic recovery. With the program now ending, the focus should be on structural reforms to improve competitiveness, and preventing vulnerabilities from re-emerging.

"The 2012 budget, which aims for a deficit below 2.5 percent of GDP, demonstrates the authorities' commitment to fiscal discipline and to meeting the Maastricht criteria. However, alternative measures such as higher real estate tax, progressive personal income tax, and improved targeting of social benefits, might have proved less distortionary and facilitated a more sustainable adjustment. Continued high unemployment and poverty rates make it important to maintain a strong social safety net.

"Greater harmonization of the Bank of Latvia's decision making with the ECB would support the fixed exchange rate and mitigate pressures on international reserves.

"After completing the orderly sale of the commercial part of Mortgage and Land Bank, safeguards should be put in place to prevent the remaining institution from becoming a future source of fiscal and financial stability risk. Financial sector supervision should be strengthened to make sure the problems in Latvijas Krajbanka are contained.

"The problems in airBaltic demonstrate the importance of strengthening governance in state-owned enterprises. The authorities should consider all options if efforts to return the airline to profitability fail, to ensure public money is not wasted." 


\section{Statement by Mr. Benny Andersen, Executive Director for Latvia and Mr. Gundars Davidsons, Advisor to Executive Director \\ December 21, 2011}

Though Latvia's average growth rate over the last decade has been in line with that of other countries of the region, the same cannot be said of the volatility. Following the EU accession, three years of boom with growth rates of over 10 percent and current account deficits in the double digits resulted in an all too predictable bust in 2008. Since then, the economy has successfully recovered from the slump, and with the 3rd quarter GDP growth rate of 6.6 percent Latvia again ranks among Europe's best growth performers. Consequently, unemployment has declined from the crisis peak of 20.7 percent to 14.6 percent in the 3 rd quarter of 2011 and strong economic growth also shows up in better than expected tax revenues.

Today, after three years under the program and a successful return to markets in 2011, the authorities face new challenges, this time related to the possible slowdown of the global economy.

\section{The Latvian authorities have successfully implemented their strategy}

The arrangement, which started out as a highly contentious case, turned out to be among the few in which the authorities' strategy was consistently implemented right to the end of the program. In 2008, few believed the program would succeed, also at the Fund. Most of the forecasts were grim, and the rather heterodox "alternative strategies" proposed by experts usually involved confidence-damaging violations of property rights like currency conversion of loans. The authorities chose their own strategy and, if compared to all the rather gloomy 2009 forecasts, it turned out to be a success. The first review staff report (EBS/09/122) is a good example of the prevailing thinking at the time; with the staff's program scenario government debt projected to reach 87 percent of GDP in 2011. The actual figure will likely be below 45. The GDP growth, current account adjustment, exports, even the rate of unemployment all came out much better than expected in 2009.

The output collapse and correspondingly high unemployment were inevitable in any adjustment scenario; they were not inherent only to the authorities' strategy. Given the magnitude of the preceding unsustainable boom, large adjustment costs in terms of output decline and high unemployment were unavoidable during the following recession.

The economy has successfully re-adjusted towards a more export-oriented model. At the outset of the program, the mechanism of adjustment under the fixed exchange rate was not understood by many and a severe and prolonged "competitiveness problem" was predicted. Those pessimistic forecasts turned out to be wrong. To illustrate the point, it is sufficient to compare the current projections of manufacturing exports in 2011 with the corresponding staff projection from the first review paper; the fact has outperformed the 2009 projection by 70 percent. A similar error was made in the case of the other two Baltic countries, also under fixed exchange rate regimes. The economies turned out to be sufficiently flexible to quickly regain competitiveness through internal adjustment. 
Looking forward, the prospect of a new recession poses new challenges

While the authorities' strategy has helped to improve cost competitiveness and restore growth, the prospect of a global slowdown poses new risks. As a small open economy, Latvia will always be dependent on external markets. While Latvia's major exports markets are less affected by the sovereign debt crisis, the first signs of decelerating export demand are already observable. The working day adjusted manufacturing output and manufacturing exports growths have slowed in October. The successful reorientation of the economy towards the tradable sector also means that the export share in the economy has increased significantly over the recent years increasing the economy's vulnerability to external demand shocks.

Even though the recent quarters recorded an ongoing healthy expansion of export market shares, pointing to a strong competitive position of Latvian exporters, further competitiveness gains are essential to cushion adverse external demand developments. To support competitiveness, the authorities will continue to implement their structural reform agenda, including such measures as (1) improving the business environment and ensuring the efficient use of EU structural funds and the adequate access to finance for companies, (2) implementing measures to reduce structural unemployment, and (3) moving forward with the reform of the education system to improve the quality and international competitiveness of educational institutions, and to better link higher and vocational education with labor market demands.

Despite the recent sovereign debt crisis escalation in Europe, the authorities are committed to the euro adoption goal. The Latvian authorities' strategy remains to reach a sustainable level of economic convergence to qualify for the euro introduction in 2014. The authorities do not feel comfortable with the staff report debating the prospect, and even the rationale, of the euro introduction (e.g., para. 10, page 9) without discussing this issue properly with the authorities.

Ensuring fiscal sustainability and implementing further structural reforms remains high on the political agenda

The Latvian authorities are ready to face the challenges of a possible global slowdown. The current plans already include some buffers: a relatively conservative GDP projection for 2012 (around 1 percentage point below those for other Baltic countries) and the deficit target of 0.5 percentage points below the Maastricht reference value provides room for maneuver in case the recession turns out to be worse than expected. In addition, the authorities' revenue projection for 2011 is rather conservative and recent data indicates the actual outcome is likely to be better than envisioned in the staff report. In case of an even deeper recession, the authorities are ready to take additional measures to keep the deficit within the limits of the Maastricht criteria.

The Latvian authorities are committed to prudent budget planning and its strong implementation in the coming years. The government has submitted to the Parliament the 
Fiscal Discipline Law and respective amendments to the Constitution laying the foundation for future counter-cyclical fiscal policies. The Latvian authorities will continue to improve the tax collection system to increase tax compliance; and the Fund's technical assistance recommendations will be implemented to reduce the gray economy.

Additional measures have been taken to maintain the social safety net and address the sustainability issues of the social system in general. They aim to keep the current social safety net in place, to maintain its spending at 0.4 percent of GDP, and to co-finance GMI payments in 2012 and the housing benefit until end-April 2012. The authorities also plan to frontload the pension reform increasing the early and statutory retirement ages and the qualification period for retirement already from 2014 (previously scheduled to 2016).

The authorities aim for further strengthening of the banking regulations in line with the EU legal acts which will improve capital quality, ensure sufficient liquidity, and limit banks' leverage. The authorities will continue their tight supervision of the financial system, and they reiterate their commitment to strengthen banks' capital base, including by waiving the transitional period for capital requirements foreseen in the Capital Requirements Regulation. They will continue to make the utmost use of their supervisory powers to impose higher capital requirements for those banks whose business model is oriented toward servicing nonresidents that entail additional risks. In light of the recent developments with Latvijas Krajbanka, the authorities envision strengthening the FCMC's capacity to conduct forensic investigation. Criminal Law will also be amended to strengthen the responsibility for the submission of deliberately distorted or incomplete information to the supervisory authority.

\section{Latvia's monetary policy strategy of maintaining a fixed (narrow band) exchange rate} will remain in place until the euro adoption. While the authorities are committed for their main refinancing rate to converge to that of the ECB in the run-up towards the euro, the experience of other countries with a (narrow band) peg to the euro suggest that a small spread between their and the ECB's policy rates can be sustained over time, and that a perfect match of policy rates is not necessarily a precondition to support a fixed exchange rate. The recent loss of reserves was related to the drawdown of government's foreign exchange denominated funds at the BoL to finance Treasury's funding needs; most of which were one-off funding requirements related to the repayment of state-guaranteed deposits at Latvijas Krajbanka. This would have happened irrespective of the interest rate spread. Also, at present, all the official interest rates set by the BoL are either higher or equal to the interest rates set by the ECB. The same can be observed in the case of many of the money market interest rates including the most important market indices for 3 and 6-month maturities. Spreads in case of shorter maturities are small and narrowing.

\section{Looking forward, the government is stepping up its efforts to address the underlying} weaknesses of the economy. With low labor cost production no longer a viable option under the EU free movement of labor policy, the economy's future depends on growth-enhancing reforms and the ability to move the economy up the value added ladder. One of the government's key priorities will be an all-encompassing modernization of the education system. While those reforms are expected to bear fruit over the medium term, the authorities 
are also taking measures to improve the business climate today. Those ongoing efforts have not been left unnoticed. In 2011, Latvia ranked 21 in the World Bank Doing Business ranking, improving its ranking from the previous year by ten positions. While this index covers a rather narrow set of indicators, it does reflect the authorities' commitment to pursue the necessary reforms to make the economy more attractive for potential investors.

\section{Overall, the cooperation with the Fund has been successful, yet some lessons could be learned from past experience}

The authorities would like to thank staff for the close cooperation and its helpful advice in shaping and implementing their strategy throughout the past three years. Without the support and advice provided by staff, Latvia would have been worse off in faring through the recent crisis. However, some issues could be outlined which if addressed in a different way could have led to a superior outcome.

In its initial stage, the program was not successful in anchoring confidence. An important element of economic stabilization was regaining the confidence of domestic and international markets. The Fund was not very successful in helping the authorities bestow this confidence in 2008 and 2009 and markets perceived that staff was questioning the viability of the authorities' strategy. The discussion of alternative adjustment scenarios in early staff reports did not help and was perceived as a clear signal to pile up bets on Lat devaluation inducing an even stronger current account turnaround and an equally large GDP contraction. The authorities still believe that the Fund could have done more in backing the confidence to the program ownership, particularly at its early stage.

\section{With the benefit of hindsight, political risks and the "competitiveness problem" have} been grossly exaggerated. Instead of the riots and political instability predicted by experts, the political process under the program demonstrated an uncharacteristic stability in Latvia's parliamentary system. The 2011 snap parliamentary elections resulted in Mr. Dombrovskis taking the office of prime minister for the third time in a row, hence becoming one of the most long-lasting prime ministers in office since the restoration of Latvia's independence.

More focus on structural issues would have been appreciated. An inadequately high share of resources were devoted to issues that provided little value added to the authorities, like exchange rate assessment and discussions on price competitiveness, particularly during the first half of the program. At the same time, other issues like the quality of governance, administrative capacity deficiencies, and non-price competitiveness remained largely neglected under the program. While those issues are weakly linked with the Fund's mandate, they have a direct impact on countries' growth potential, the importance of which is reconfirmed by the ongoing sovereign debt crisis. 